\title{
21. PUŁK PIECHOTY VON BORCKE (4. POMORSKI) W BITWIE POD BOLIMOWEM W ŚWIETLE BADAŃ ARCHEOLOGICZNYCH
}

SŁowa KLuCzowe: I wojna światowa, badania archeologiczne pól bitewnych, źródła historyczne w badaniach archeologicznych

KEYwords: World War I, archaeological investigations of modern battlefields, archaeological and historical sources

\section{WSTĘP}

Pola bitew stały się obiektami zainteresowań archeologów polskich ponad pięćdziesiąt lat temu. Wystarczy tu jedynie przypomnieć wieloletnie badania pobojowiska grunwaldzkiego rozpoczęte w 1958 r. i trwające z mniejszymi lub większymi przerwami oraz sukcesami do chwili obecnej. Poza Grunwaldem prace archeologiczne prowadzono do końca XX wieku, m.in. pod Cedynią, Legnicą, Płowcami, Raszynem, Świecinem i Lubiszewem. Ich szczegółowe wyniki zostały opublikowane w literaturze fachowej. Wybrane zespoły przestrzenne o określonych wartościach przyrodniczo-historycznych związane z bitwami (Grunwald, Maciejowice, Racławice, Raszyn) zostały objęte konserwatorską ochroną. Analogiczne prace podjęto również na początku naszego stulecia m.in. na terenach bitew wojny siedmioletniej pod Sarbinowem, woj. zachodniopomorskie i Kunowicami, woj. lubuskie (Wrzosek 2010). W tym też czasie narodziła się wśród badaczy potrzeba usystematyzowania i pogłębienia refleksji nad tymi zagadnieniami owocująca pojawieniem się syntetyzujących opracowań dziejów oraz sformułowaniem celów i metod takich badań (Olejnik 2006; Wolski 2008, tam obfita literatura). Rodzi się pojęcie ,archeologia pól bitewnych”. Za jeden z jej priorytetów uznawane jest przywracanie społecznej pamięci o takich miejscach i włączanie ich do ruchu turystycznego (Chylińska, Kosmala 2011; Chylińska 2013).

Przedmiotem zainteresowania stały się równocześnie obiekty militarne odkrywane poza przestrzeniami bitew, niejako przy okazji badań na stanowiskach 
pradziejowych, średniowiecznych i wczesnonowożytnych. Były one początkowo traktowane po macoszemu przez badaczy zajmujących się klasycznymi gałęziami archeologii. Dotyczyło to szczególnie pozostałości XX-wiecznych walk toczonych na wielkich przestrzeniach i posługujących się bronią i techniką groźną do dzisiaj dla podmiotu badań. Czynnikiem hamującym właściwe nastawienie poznawcze archeologów była też świadomość względnie krótkiego odcinka czasu, jaki upłynął od tych wydarzeń. Przyjmowano bowiem milcząco, że powinny być one raczej przedmiotem badań znawców nowożytnej wojskowości, broni palnej lub mundurologów. Do zagadnienia tego powrócimy na końcu naszych rozważań. Zasadniczy zwrot $\mathrm{w}$ takim podejściu wymusiły m.in. odkrycia pozostałości bitew z czasów Wielkiej Wojny 1914-1918 na szerokopłaszczyznowych stanowiskach autostradowych pod Bolimowem, pow. skierniewicki. Na ich kanwie podejmowane są próby metodologicznego zdefiniowania zakresu ,archeologii pól bitewnych”, zwanej też niekiedy „archeologią konfliktu”, jako nauki stosowanej, animującej i obsługującej żywą, „biograficzną” pamięć społeczną (Zalewska 2013: 37-45). Obecnie nikt już nie kwestionuje konieczności i potrzeby prowadzenia badań XX-wiecznych obiektów militarnych traktowanych równorzędnie, np. ze średniowiecznymi lub nowożytnymi warowniami.

W niniejszym artykule podejmujemy ten temat stawiając sobie dwa główne cele. Pierwszym z nich jest przedstawienie jednego z bardziej spektakularnych wątków badań archeologicznych na trasie planowanej budowy autostrady A2 pod Bolimowem, czyli śladów pobytu i działań w tym miejscu wojsk niemieckich w okresie od grudnia 1914 do maja 1915 roku. Materiału do naszych rozważań dostarczyły wyniki prac wykopaliskowych na dwóch stanowiskach archeologicznych. Były to: stanowisko nr 9 w Bolimowie badane w 2005 r. przez Instytut Archeologii i Etnografii PAN w Łodzi ${ }^{1}$ i stanowisko nr 2 w Joachimowie-Mogiłach ${ }^{2}$, pow. skierniewicki (ryc. 1). Obie akcje sfinansowane były przez Generalną Dyrekcję Dróg Krajowych i Autostrad. Przy okazji spróbujemy sformułować spostrzeżenia i wnioski dotyczące uwarunkowań i metod badań dwudziestowiecznych pól bitewnych oraz czasami niezbyt rozważnych lub nazbyt gorączkowych działań ludzi zainteresowanych tym tematem. Drugim naszym podstawowym celem jest próba skonfrontowania anonimowego materiału zabytkowego $\mathrm{z}$ wiedzą historyczną zaczerpniętą z opublikowanych opracowań i relacjami naocznych świadków.

${ }^{1}$ Konsultantem badań ze strony Instytutu Archeologii i Etnologii PAN był prof. dr hab. Tadeusz Poklewski, koordynatorem doc. dr hab. Jerzy Maik, pracami w terenie kierował dr Piotr Świątkiewicz (zob. Świątkiewicz 2010; 2011).

2 Wykonawcą prac było Przedsiębiorstwo Archeologiczno Konserwatorskie „KAIROS-PLUS", działające w ramach umowy z Fundacją Uniwersytetu Łódzkiego. Pracami bezpośrednio kierowała mgr K. Zagórska (zob. Olejnik i in. 2010). 


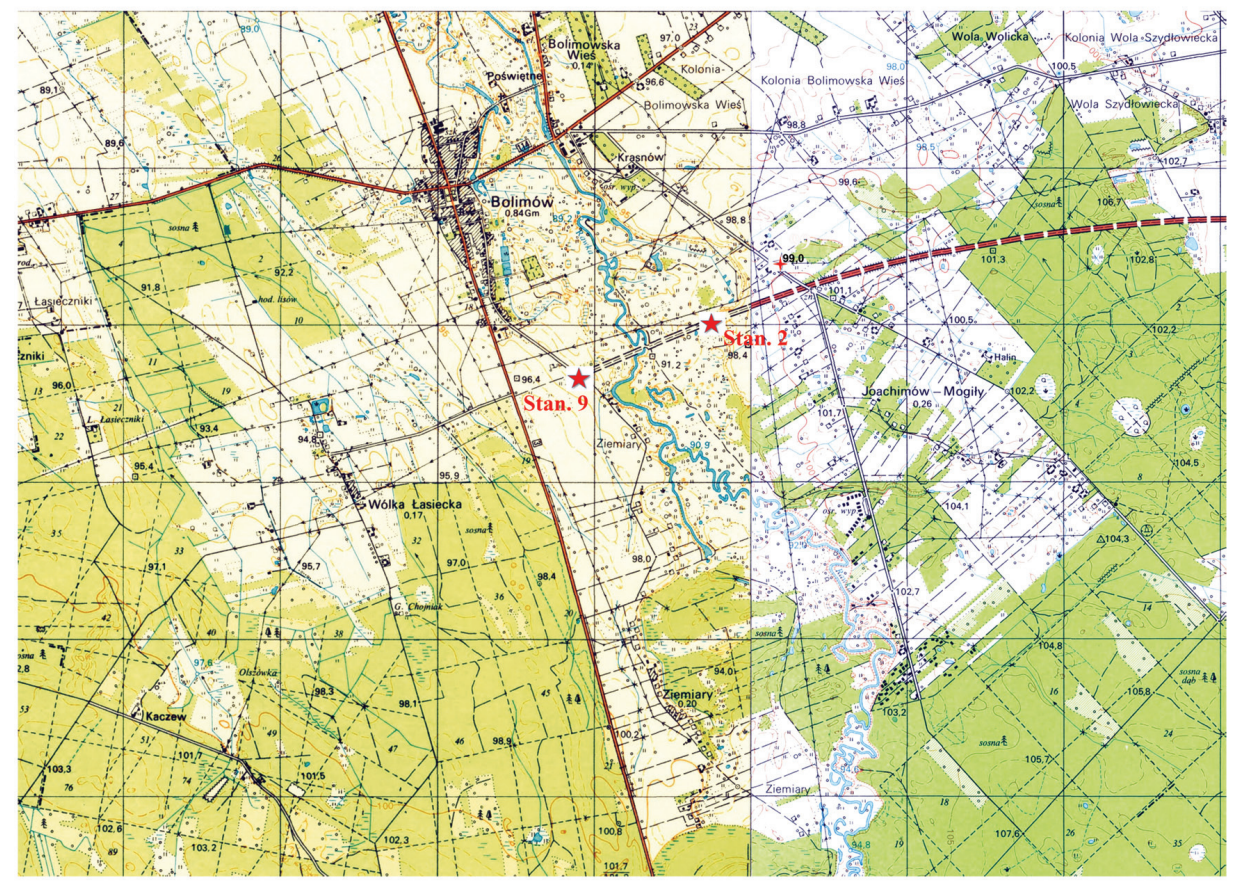

Ryc. 1. Położenie stanowisk $9 \mathrm{w}$ Bolimowie i $2 \mathrm{w}$ Joachimowie-Mogiłach (wyk. K.E. Natkański).

\section{BOLIMÓw, GRUDZIEŃ 1914 ROKU - MAJ 1915 ROKU}

Ogólną sytuację historyczno-militarną i najbardziej istotne epizody działań wojennych w okolicy Bolimowa w czasie Wielkiej Wojny kompetentnie przybliżył Stanisław Kaliński opierając się m.in. na wielu materiałach źródłowych, w tym na licznych historiach wojennych pułków niemieckich, opublikowanych w latach między I a II wojną światową (Kaliński 2010; 2015). Zamieszczony niżej krótki opis tych wydarzeń oparliśmy na opracowaniach tego autora uzupełniając je tylko innymi informacjami. Pochodzą one głównie, choć nie tylko, z nieuwzględnionej przez S. Kalińskiego książki zawierającej opis frontowych działań pruskiego 21. Pułku Piechoty (4. Pomorskiego) von Borcke z Torunia wchodzącego w skład 35. Dywizji Piechoty XVII Korpusu Armii generała dywizji Günthera von Pannevitz (Kriegsgeschichte...) ${ }^{3}$. Wykorzystanie tej relacji nie było przypadkowe, gdyż posłużyło do realizacji wspomnianego we wstępie celu.

\footnotetext{
${ }^{3}$ Wcześniejsze dzieje pułku opisuje G. Schreiber (1889). Inne źródła to uwzględnione przez S. Kalińskiego wielotomowe opracowanie Weltkrieg..., t. VI, VII, VIII.
} 


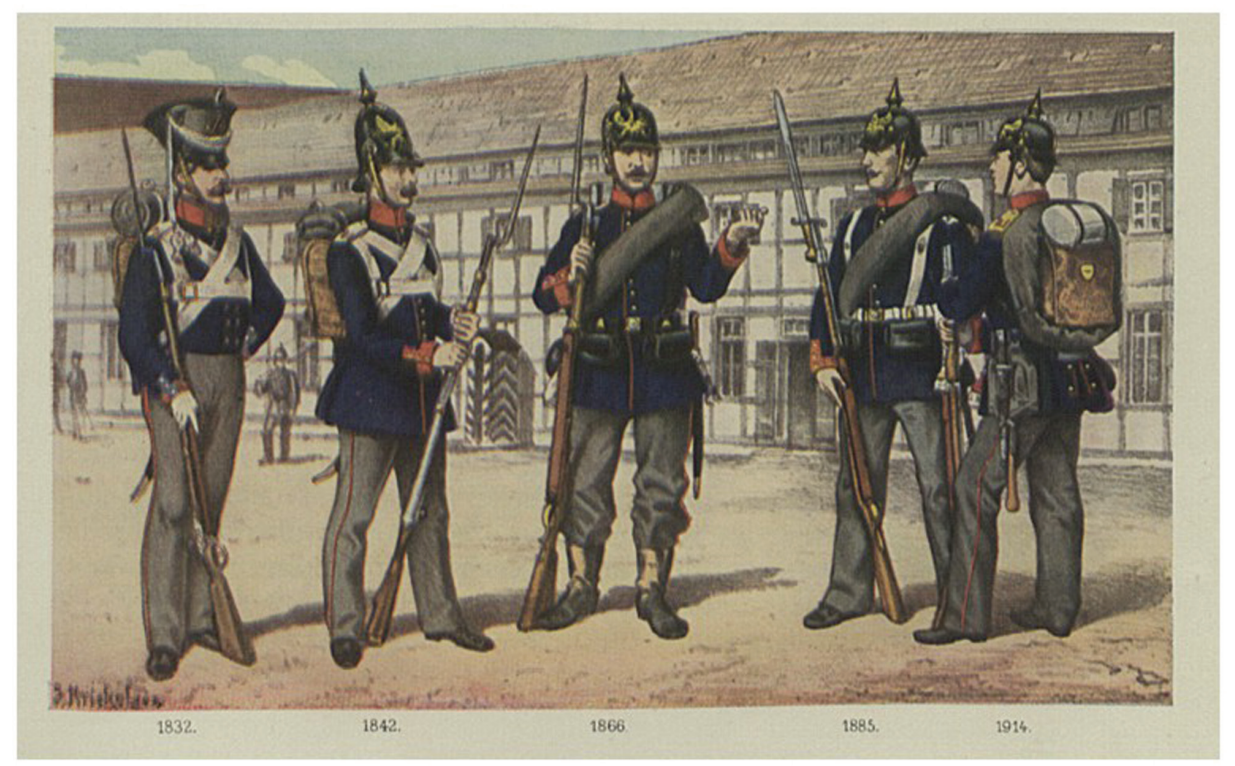

Ryc. 2. Umundurowanie żołnierzy 21. Pułku Piechoty von Borcke w latach 1867-1914. (Kriegsgeschichte..., Tafel I).

Od 1867 r. do Wielkiej Wojny żołnierze tego pułku nosili mundury składające się głównie z szarych spodni z czerwonymi lampasami oraz granatowych kurtek (Waffenrock) z czerwonymi kołnierzami i wyłogami na rękawach oraz białymi naramiennikami z czerwonym oznakowaniem pułku (ryc. 2). Na kwadratowym sztandarze pułku przestawiony był żółty krzyż w formie Żelaznego Krzyża (Eisernes Kreuz), w centrum którego czarny orzeł z rozpostartymi skrzydłami, pod pruską koroną i napisem: PRO GLORIA ET PATRIA trzymał w jednym szponie błyskawicę, a w drugim miecz (Infanterie-Regiment...).

Ostatnim komendantem pułku w czasie pokoju był pułkownik (później generał dywizji) Lutz von Dewitz (ryc. 3). Po mobilizacji przeprowadzonej na mocy rozkazu z 2 sierpnia 1914 r. jego dowódcą został 3 sierpnia podpułkownik, a od 19 sierpnia pułkownik Hans Brunnemann (ryc. 3). Dowódcą pierwszego batalionu był major von Olszewski (a od 1 stycznia 1915 r. major Steffen), drugiego major von Köhler, a trzeciego major Wagner (od 1 stycznia 1915 r. kapitan Grashoff (Kriegsgeschichte...: 40-43, 170). 9 sierpnia 1914 r. pułk ruszył na wojnę. Po zwycięskiej dla wojsk cesarko-niemieckich „bitwie łódzkiej” wyruszył 23 li-

${ }^{4} \mathrm{~W}$ cytowanym źródle często brakuje imion występujących w nim osób. Imiona dowódców 21. Pułku zaczerpnęliśmy z internetowego portalu (zob. Infanterie-Regiment...). 


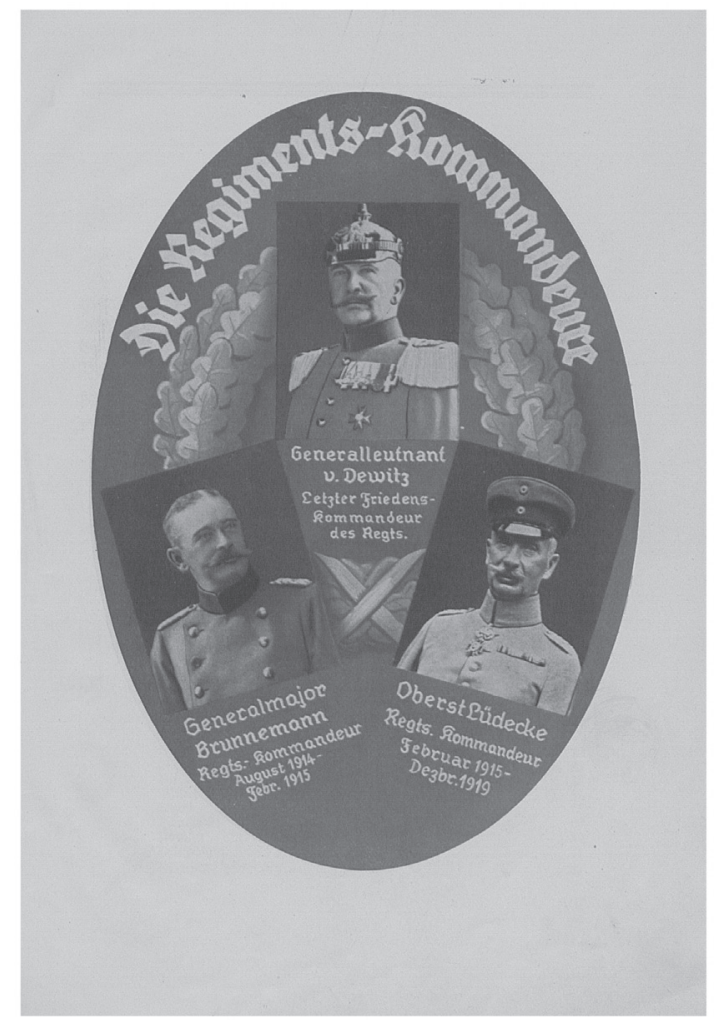

Ryc. 3. Dowódcy 21. Pułku z 1914/1915 r.; Generalleutnant L. von Dewitz, Generalmajor (wcześniej Oberst) H. Brunnemann, Oberst J. Lüdecke (Kriegsgeschichte..., wkładka).

stopada forsownym marszem spod rogatek Zgierza przez Piątek, Żychlin i Kutno kierując się na Łowicz, pod którym stoczył pomyślną dla siebie potyczkę. 24 grudnia przekroczył koryto Rawki i dotarł w okolice wsi Kurabka pod Bolimowem, gdzie na północ od Borzymowa obsadził odcinek frontu zu Kurabka o długości około $1 \mathrm{~km}^{5}$.

Bolimów od grudnia 1914 r. znajdował się w strefie operacyjnej 9. Armii niemieckiej dowodzonej przez feldmarszałka Augusta von Mackensena (ryc. 5). Miasto zostało zdobyte 18 grudnia przez pododdziały 1. i 36. Dywizji Piechoty (Kaliński 2010: 27-28; 2015: 48) ${ }^{6}$. Następnego dnia zajęto przyczółki na

${ }^{5}$ Opis szlaku bojowego 21. Pułku od „bitwy łódzkiej” do maja 1915 r. według Kriegsgeschichte..., Teil 1. Feldzug in Ostpreußen und Polen (16.5.1914-15.5.1915), Karte 14: Major Vetter: 133-169.

${ }^{6}$ Według niektórych niemieckich źródeł Bolimów zdobyto 19 grudnia 2014 r. (zob. Weltkrieg..., t. VI: 313). 


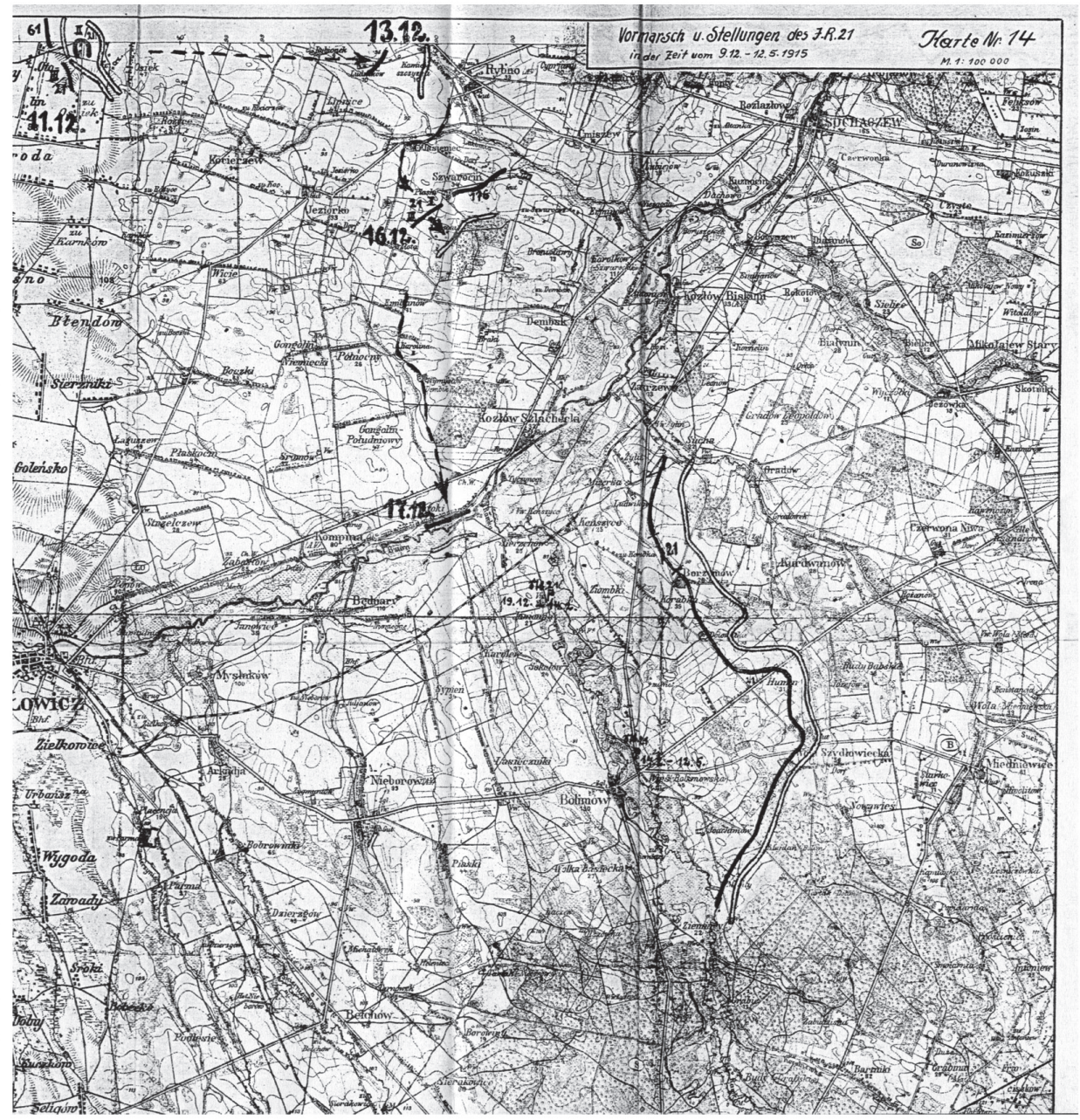

Ryc. 4. Przemarsze i pozycje 21. Pułku od 9 grudnia 1914 r. do 12 maja 1915 r.

(Kriegsgeschichte..., Karte 14).

wschodnim brzegu Rawki na wysokości Sokołowa i Ziąbek. Rosjanie wycofali się praktycznie bez walki na pozycje obronne przygotowane wcześniej na terenie górującym nad płaską i podmokłą doliną rzeki. W dniu 20 grudnia odcinek frontu od Sokołowa do Ziemiar znalazł się w strefie operacyjnej jednostek wchodzących w skład II Korpusu generała armii Alexandra von Linsingen. Na jego lewym skrzydle do Kęszyc stał XVII Korpus z 21. Pułkiem, a na prawym I Korpus Rezerwowy z Prus Wschodnich generała dywizji Kurta von Morgen. W dniu 


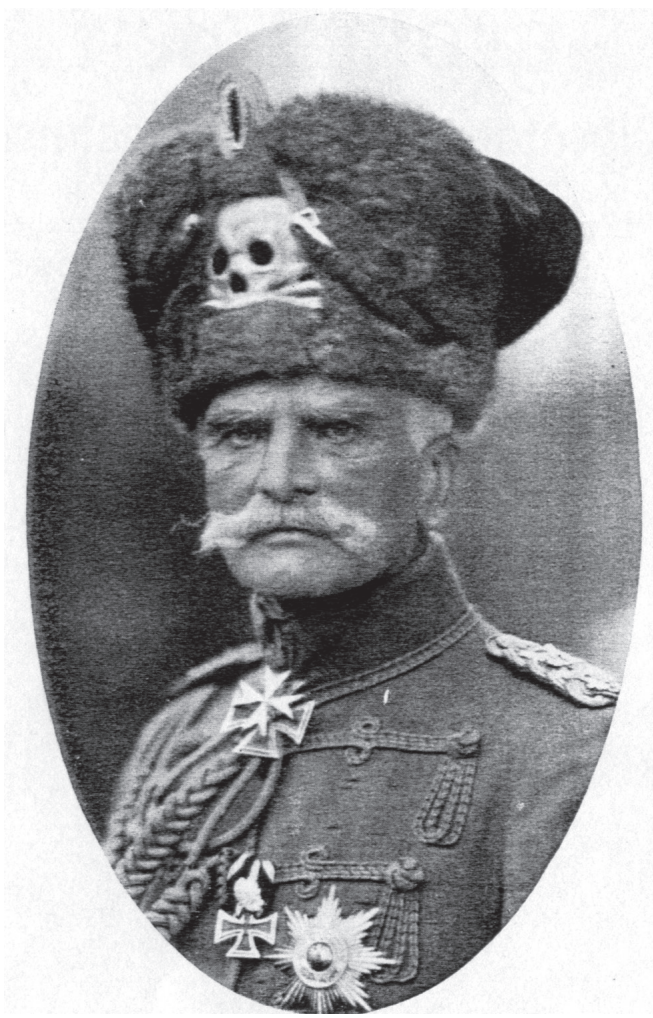

Ryc. 5. Feldmarszałek A. von Mackensen (Kriegsgeschichte..., wkładka).

20 grudnia oddziały niemieckie przekroczyły Rawkę po moście postawionym około 1,5 km na północ od Bolimowa i w ciężkich bojach dotarły do przednich rosyjskich pozycji obronnych rozmieszczonych we wsiach: Mogiły, Wola Szydłowiecka, Dołowatka, Humin i Kurabka. Na szczególnie interesującym nas odcinku frontu obejmującym Bolimów 14. i 149. pułki piechoty Korpusu Linsingena do 22 grudnia zdobyły wysunięte okopy rosyjskie na zachodnim skraju Humina. Dalszy postęp wojsk niemieckich na odcinku Mogiły - Dachowo był jednak skutecznie blokowany przez Rosjan broniących pozycji uprzednio rozbudowanych w postaci kilku liniowych transzei i bastionów. Niewiele pomogto w tym względzie utworzenie 27 grudnia z II, XIII i XVII Korpusu szturmowej Grupy dowodzonej przez generała A. von Linsingen. Jedynie w pierwszych dniach stycznia 1915 r. udało się 128. Pułkowi Piechoty i 5. Pułkowi Grenadierów zająć wschodni skraj Borzymowa, a 1. Rezerwowej Dywizji wieś Mogiły (Kaliński 2010: 27-28, 32-33, 35, 37, 52; Weltkrieg..., t. VI: 359). 
Jak pisze S. Kaliński, na tym etapie walk żołnierze niemieccy szukając schronienia przed ogniem nieprzyjaciela mogli jedynie korzystać z naturalnych zagłębień terenu i doraźnie kopanych w zmarzniętym gruncie dołków strzeleckich. Niekiedy wzmacniano i ulepszano je przynoszonymi np. workami piasku oraz wiązkami siana. W czasie jednego $\mathrm{z}$ ataków na wieś Mogiły w dniu 4 stycznia 1915 r. osłonę przed pociskami stanowiły zwłoki poległych towarzyszy broni. Lepsze warunki przetrwania na froncie uzyskiwano zdobywając pozycje rosyjskie. Bezpośrednio za jego linią żołnierze kwaterowali przeważnie w płytkich, prowizorycznych ziemiankach i jedynie wyjątkowo w zniszczonych zabudowaniach pobliskich wsi. Z relacji odnotowanych w historii 21. Pułku dowiadujemy się (Kriegsgeschichte...: 159-160, tłumaczenie autorów), że już pozycje osiągnięte pod wsią Kurabka 24 grudnia:

[...] musiały być z wielkim trudem i nakładem pracy rozbudowywane, starano się budować rowy osłaniające i łącznikowe oraz schrony, a wszystko w terenie składającym się głównie z błota i bagniska, gdzie woda gruntowa występowała prawie pół metra pod powierzchnią i do tego w porze roku, w której przeplatały się opady deszczu i śniegu.

W trybie normalnego, 24. godzinnego luzowania zazwyczaj jeden batalion (pułku) obsadzał przednie umocnienia, inny pozostawał w gotowości w ziemiankach położonych $\mathrm{z}$ tyłu, a trzeci batalion w odwodzie przy sztabie pułku (Kaliński 2010: 35, 38, 52; 2015: 57). Jednak nie zawsze i nie wszyscy przebywali w spartańskich warunkach. Prawdopodobnie w jednej ze sztabowych kwater przynajmniej część oficerów spędziła sylwestrową noc 1914/1915 r. w dość luźnej atmosferze (ryc. 6). Uwiecznieni w tej sytuacji na zdjęciu w cytowanej książce porucznicy D. Dahle, G. Kuhn i Bräckow wystąpią jeszcze w naszej relacji w zgoła innych okolicznościach.

Siódmego stycznia nastąpiła poważna reorganizacja struktury dowodzenia odcinkiem frontu biegnącym od Ziemiar do Kęszyc. Rozwiązano Grupę von Linsingena, a jej pozycje między Ziemiarami a Huminem zajęły jednostki I Korpusu Rezerwowego generała K. von Morgen w składzie: 4. Dywizja Piechoty pod dowództwem generała brygady Ericha Freyera, 49. Dywizja Rezerwy generała brygady Victora Hahndorfa, 1. Dywizja Rezerwy generała dywizji Arthura S. von Förstera i 36. Dywizja Rezerwy generała brygady Curta Kruge (Weltkrieg..., t. VII: 462-463). Najbardziej interesujący nas odcinek między drogą Bolimów - Wola Szydłowiecka i Mogiłami obsadziła 49. Dywizja Rezerwy w składzie: 225., 226., 227. i 228. Pułk Rezerwy oraz 21. Rezerwowy Batalion Strzelców. Dalej na południe do wsi Ziemiary w okopach znajdowali się żołnierze 36. i 1. Dywizji Rezerwy, a na północ 
od Bolimowa 3. i 4. Dywizji Piechoty. Na lewym skrzydle 1. Korpusu rozmieszczono oddziały 35. i 36. Dywizji Piechoty XVII. Korpusu. Zrezygnowano także $\mathrm{w}$ tym czasie $\mathrm{z}$ metody atakowania $\mathrm{w}$ każdym przypadku $\mathrm{w}$ gęstych kolumnach, kładąc nacisk na budowę pozycji szturmowych w postaci okopów prowadzących do umocnień wojsk rosyjskich. Były one stopniowo wzmacniane, początkowo doraźnie np. przynoszonymi przez żołnierzy belkami, deskami lub wyjętymi z wiejskich chat drzwiami, później dostarczanymi płytami stalowymi (Grabenschutzschilds) o wymiarach $45 \times 60 \mathrm{~cm}$. Ocieplano je także sianem, a ziemianki na pozycjach rezerwowych niekiedy piecykami. Pozycje te rozbudowywano m.in. o stanowiska nasłuchowe i rowy łącznikowe, tworząc system umocnień umożliwiający bezpieczny pobyt żołnierzy oraz zorganizowanie niespodziewanego ataku i efektywnej obrony (Kaliński 2010: 58). Przedsięwzięcia te wymagały ogromnego żołnierskiego wysiłku i nie zawsze przynosiły spodziewane efekty. W wojennej historii 21. Pułku zapisano pod dniem 28 stycznia m.in. (Kriegsgeschichte...: 162, tłumaczenie autorów):

W śniegu i deszczu, w straszliwym błocie i mule musiały być kopane nowe stanowiska. Także ziemianki i prymitywne schrony, w których przebywały odwody i rezerwy tonęły często w gruntowej wodzie. Tylko z trudem udawało się ochronić oddziały przed kaprysami pogody, które pochłonęły niejedną ofiarę.

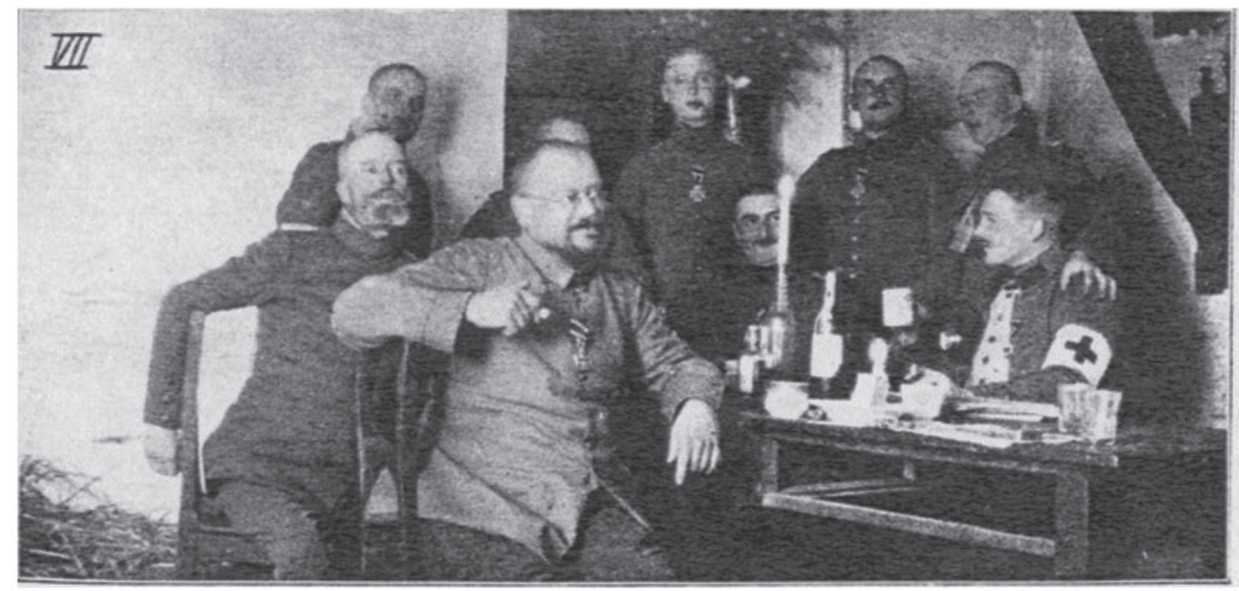

Ryc. 6. Oficerowie 21. Pułku w noc sylwestrową 1914/1915 r. pod Kurabką; porucznik Schrader, major von Koehler, dr Holland, porucznik Dahle, porucznik G. Kuhn, porucznik E. Sommerfeldt, porucznik Bräckow, dr J. Wolff (Kriegsgeschichte..., Tafel 6/VI). 
Po kilku nieudanych próbach przełamania pozycji rosyjskich m.in. w majątku Dołowatka, w Borzymowie i w rejonie Mogił, przeprowadzonych w połowie stycznia 1915 r., dowództwo 9. Armii zdecydowało w dniu 19 stycznia 1915 r. o podjęciu „rozstrzygającego natarcia” przeciwko wojskom rosyjskim na odcinku Mogiły - Wola Szydłowiecka - Humin - Dachowo (Weltkrieg..., t. VII: 164). Natarcie to miało się odbyć m.in. siłami I Korpusu wzmocnionego połową 3. Gwardyjskiej Dywizji Piechoty oraz XVII Korpusu. Oddziały artylerii otrzymały do dyspozycji 18000 pocisków z gazem łzawiącym (bromkiem ksylitu). Natarcie, w którym uczestniczyły także pododdziały 1. i 49. Dywizji Rezerwy, rozpoczęło się 31 stycznia głównym uderzeniem na Wolę Szydłowiecką - Borzymów. Jedynym sukcesem było zajęcie i utrzymanie majątku w Woli Szydłowieckiej i Huminie. Podczas tych walk nie zabrakło bezmyślnych rozkazów pomijających najnowsze sposoby skutecznych działan ofensywnych, choć zgodnych z obowiązującymi nadal regulaminami piechoty ${ }^{7}$. W zapiskach porucznika D. Dahle, dowódcy szóstej kompanii 21. Pułku szturmującej Borzymów, znajdujemy taki fragment: (Kriegsgeschichte...: 164, thumaczenie autorów).

Aby wywierać stopniowo na Rosjanach coraz większy psychologiczny wpływ, rozkazano podczas frontalnego natarcia piechoty atakować w zwartym szyku w pozbawionym osłony terenie widocznym z rosyjskich okopów. O godz. 10.15 ustawiły się kompanijne kolumny; na czele zastępca dowódcy pułku major von Keiser ze swoim adiutantem kapitanem Vetter'em, jak również dowódca 2. batalionu major von Koehler z lejtnantem Kuhn'em [...]. Po dwie kompanie z boku i z tyłu! 7. Kompania (lt. Bräckov) i 6. (lt. Dahle) kompania maszerowały z przodu, z nimi podążały 5. i 8. Kompania (21. Pułku).

Jakże w innej, bardziej dramatycznej roli wystąpili tu niektórzy uczestnicy sylwestrowego przyjęcia na pozycjach zu Kurabka. Pododdziały ustawione prawie jak na placu defiladowym nacierały na pozycje rosyjskie w odkrytym terenie na odcinku $1500 \mathrm{~m}$, dopiero końcowe $800 \mathrm{~m}$ pokonały chowając się w zabagnionych rowach dobiegowych. Jak było do przewidzenia, szturm zakończył się dużymi stratami i powrotem żołnierzy na pozycje wyjściowe. Bohaterem tych wydarzeń został podporucznik Fritz Reiße z 3. batalionu, który wrócił nietknięty z rosyjskich okopów ${ }^{8}$. Na skutek mrozu i śniegu nie spełniły swojej roli

\footnotetext{
${ }^{7}$ Wynikały one z doktryny prowadzenia walki zwartymi ugrupowaniami, którymi można było dowodzić w polu przy pomocy głosu.

${ }^{8}$ W starciach pod Borzymowem i na pozycji zu Kurabka zginęło ogółem 3 oficerów i 204 podoficerów i żołnierzy 21. Pułku. Końca wojny nie dożyła połowa uczestników opisywanych tu wydarzeń. Porucznik F. Reiße zginął 31 lipca 1915 r. w bitwie pod Ignasinem, porucznik G. Kuhn zmarł 27 czerwca 1918 r. w szpitalu twierdzy Wrocław. Polegli także inni uczestnicy sylwestrowej biesiady 1914 r. pod Kurabką; porucznicy lekarze Eugen Sommerfeldt (24 kwietnia 1918 r.) i Johannes Wolff (9 czerwca 1917 r.) (Kriegsgeschichte ...: 164-165, 595-652).
} 
także granaty z gazem łzawiącym. Linia frontu została jedynie przesunięta na wschód o kilkaset metrów. Przeciwnatarcie wojsk rosyjskich powstrzymało dalsze działania, wojska niemieckie zostały wykrwawione, a ich początkowe sukcesy ograniczone i bez większego znaczenia. 5 lutego wydano rozkaz o wstrzymaniu natarcia i utrzymaniu zdobytych pozycji. Inicjatywa operacyjna 9. Armii została zatrzymana i jej działania ofensywne ustały do maja 1915 r. (Kaliński 2010: 64-66).

Z uwagi na duże straty, 10 lutego Naczelne Dowództwo wydało rozkaz o zdjęciu z linii frontu niektórych jednostek I Korpusu Rezerwy, w tym 4. Dywizji Piechoty. Zastąpiły je m.in. oddziały XVII Korpusu Armii, w tym pierwszy i trzeci batalion 21. Pułku, które rankiem 15 lutego przekroczyły wschodnie rogatki Bolimowa i zluzowały pozycje 14. i 140. Pułku pod Huminem, przy drodze Bolimów - Czerwona Niwa9. Natomiast „II Batalion jako dywizyjna rezerwa znalazł schronienie w obozie (Hüttenlager) pod Bolimowem (bei Bolimów)" (Kriegsgeschichte...: 166, tłumaczenie autorów). Nieco później sztab pułku dowodzonego wówczas przez zastępcę pułkownika H. Brunnemanna, majora Johannesa Lüdecke (ryc. 3) ,zajął kwatery w młynie w Bolimowskiej Wsi, tuż nad wschodnim brzegiem Rawki. Rezerwowy batalion został przeniesiony z obozu w Bolimowie do obozu na prawym brzegu Rawki, gdzie wkrótce rozpoczęto budowę nowych ziemianek (Erdhütten)" (Kriegsgeschichte...: 166, tłumaczenie autorów). Tym niemniej, dotychczasowy Reserve-Lager w Bolimowie funkcjonował nadal, a w spokojniejszym okresie od początku marca do świąt wielkanocnych 4-5 kwietnia 1915 r.

[...] został znacząco ulepszony i przystosowany do zamieszkania (wohnlicher eingerichtet). Czas spokoju został wykorzystany do doskonalenia fachowych (fachgemäß) umiejętności, doprowadzenia do porządku ubioru i uzbrojenia oraz przeprowadzenia szkoleń i apeli. W cieplejsze dni można też było zażyć w Rawce odświeżającej kąpieli $[\ldots]$

co dokumentuje załączona do wspomnień fotografia (ryc. 7; Kriegsgeschichte...: 167, Tafel 7/II, tłumaczenie autorów).

$\mathrm{Na}$ miejscu pozostała 49. Dywizja Rezerwy. Na bronione przez nią pozycje rozciągnięte między Wolą Szydłowiecką a Mogiłami Rosjanie przypuścili 24 lutego gwałtowny szturm dokonując głębokiego przełomu w rejonie Mogił, na odcinku bronionym przez 227. Rezerwowy Pułk. Został on odrzucony w stronę Rawki przez co odsłonił prawe skrzydło 21. Rezerwowego Batalionu Strzelców. Alarmowo jako odwód podniesiono do walki między innymi 3. Ba-

\footnotetext{
${ }^{9}$ Kriegsgeschichte..., Karte 14: 595-652, odręczne naniesienie. Pod Huminem zginęło 43 podoficerów i żołnierzy. Straty 21. Pułku w czasie Wielkiej Wojny wyniosły ogółem 123 oficerów i 3031 podoficerów i żołnierzy, a więc w istocie równały się z liczbą żołnierzy wyruszających na wojnę.
} 


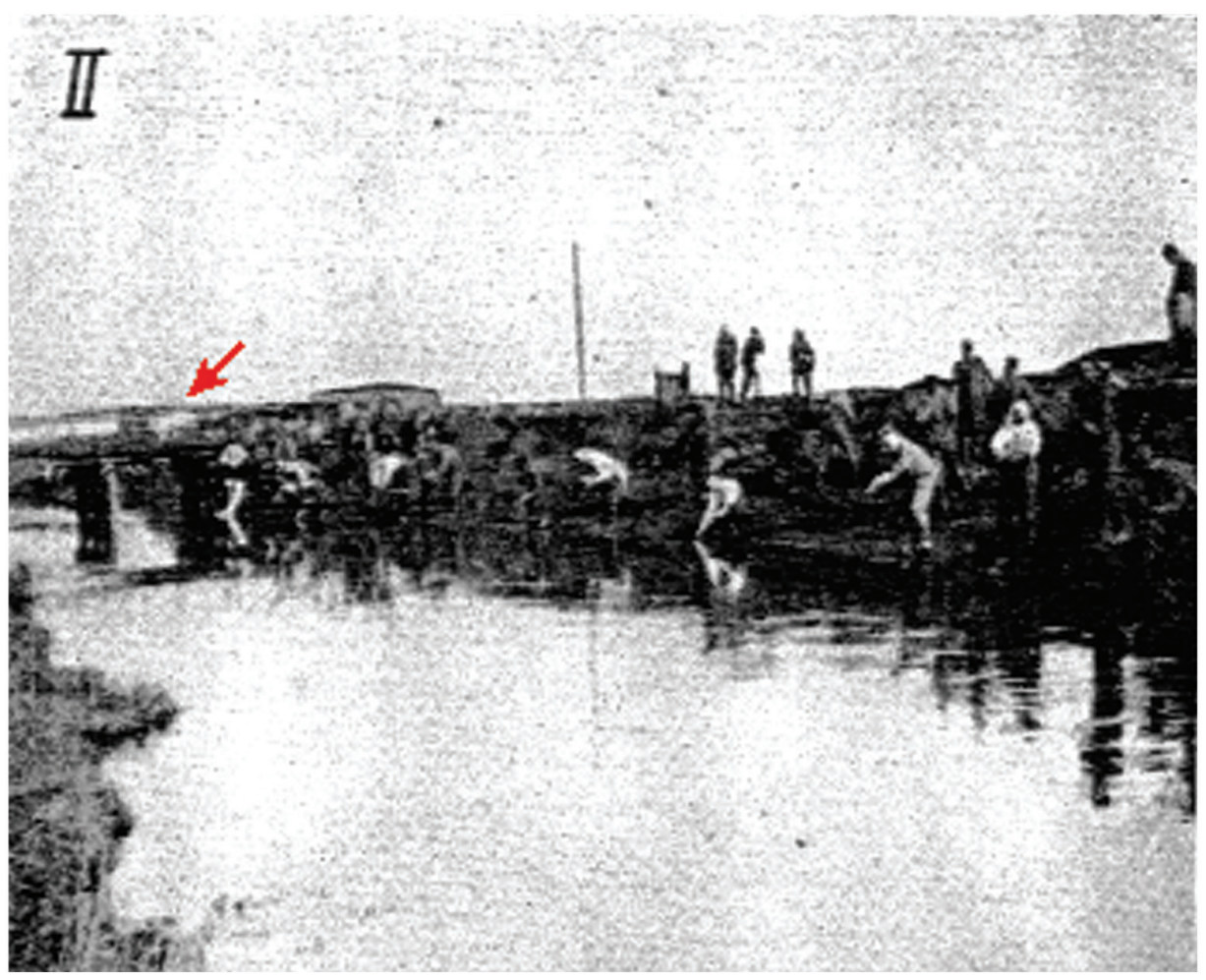

Ryc. 7. Żołnierze kąpiący się w Rawce. Strzałką zaznaczono most na Rawce (Kriegsgeschichte..., Tafel 7/II).

talion 21. Pułku Piechoty, który wymaszerował z kwater w miejscowości Wieś Bolimowska i zajął stanowiska wokół punktu topograficznego „99”, jednak w walkach nie uczestniczy ${ }^{10}$. Po trzech dniach alarmu, 27 lutego, żołnierze powrócili do kwater, a atakujących Rosjan wyparto ze zdobytych pozycji (Kaliński 2010: 87; Kriegsgeschichte...: 167).

Obrońcy tego miejsca raz jeszcze doświadczyli dramatycznych przeżyć. 1 kwietnia Rosjanie wysadzili strzeleckie stanowisko zamieniając je w gigantyczny krater, w którym na miejscu zginęło 29 żołnierzy. Był to jedyny, odnotowany na Froncie Wschodnim przypadek zastosowania technik wojny minersko-tunelowej. Nie udaje się im jednak go zdobyć, a sam lej został włączony do linii niemieckich umocnień. Jego ślad można do dnia dzisiejszego dostrzec

${ }^{10}$ Punkt ,99” znajduje się około 500 m na NE od okopów odkrytych podczas badań w $2008 \mathrm{r}$. (zob. część Joachimów-Mogity 2008 rok, także Natkański 2010). 
$\mathrm{w}$ lesie porastającym ten rejon. Zajmowane i w desperackim boju obronione stanowisko przybrało kształt trójkąta wrzynającego się w rosyjskie linie. Z tego powodu nazwano je „nosem strzelców” (Jägernase).

W dniach 11-12 maja 21. Pułk został zastąpiony przez inne pododdziały. Złożył broń i amunicję w bolimowskim obozie przekazując je jednostkom luzującym, później batalionami udał się do Łowicza, Jamna i Dąbrowic i 15 maja eszelonem wyjechał do macierzystego Torunia. Jego dalszy wojenny szlak biegł przez ówczesną Galicję (16.05.-14.09.1915), Serbię (15.09.1915-14.09.1916), Rumunię i Łotwę (27.08.1916-07.01.1917), a zakończył się we Francji.

Pułk von Borcke uniknął $\mathrm{w}$ ten sposób uczestnictwa w dalszych tragicznych wydarzeniach. W połowie maja 1915 r. sytuacja strategiczna na froncie wschodnim uległa dużym zmianom. Na skutek zwycięstw wojsk niemieckich pod Gorlicami i nad Niemnem, wojska rosyjskie na odcinku północnym i południowym cofnęły się daleko na wschód, utrzymując swoje miejsce jedynie w Polsce centralnej. Przed niemiecką 9. Armią stanęło zadanie zajęcia Warszawy. W tym celu sięgnięto po zakazaną międzynarodowymi konwencjami broń chemiczną. Zastosowano ją w okolicach Bolimowa co najmniej trzykrotnie ${ }^{11}$. Pierwszy z gazowych ataków przeprowadzono nocą z 30 na 31 maja na odcinku od Mogił aż do Bzury. Nie powiódł się on m.in. z powodu zmiany kierunku i siły wiatru. Chmura gazowa ominęła pierwsze linie obronne Rosjan i poraziła 56 żołnierzy niemieckich szturmujących pozycje nieprzyjaciela (Kaliński 2010: $109-111 ; 2015: 216,275)$. Drugi atak odbył się rankiem 12 czerwca w widłach Rawki i Bzury. Skutkował on przesunięciem frontu o $6 \mathrm{~km}$ na wschód do linii Sucha - Kozłów Biskupi. Trzeci atak gazowy miał miejsce 6 lipca 1915 r. między Kozłowem Biskupim i Huminem. Zastosowany tam wówczas chlor również poraził żołnierzy obydwu walczących stron (Kaliński 2010). Jednak decydujące przełamanie frontu nastąpiło w połowie lipca głównie wskutek wycofania wojsk rosyjskich w kierunku Wisły i zakończyło się zajęciem Warszawy przez armię cesarsko-niemiecką w dniu 5 sierpnia $1915 \mathrm{r}$.

\section{BoLiMów 2005 ROK}

Teren stanowiska $\mathrm{nr}$ 9, położonego na południowych obrzeżach Bolimowa, przecięty był funkcjonującą wówczas drogą polną prowadzącą z Bolimowa do Ziemiar. Wyraźnie rozgraniczała ona obszar badań na dwa odcinki: większy,

${ }^{11}$ Ponadto niewykonane na skutek różnych okoliczności polecenia użycia gazu wydawane były jeszcze przynajmniej dwukrotnie, tzn. 14 maja i 28 czerwca (Weltkrieg..., t. VIII: 133, 137, szkic 12). Decyzje te podejmował nowy dowódca 9 Armii, książę Leopold von Bayern, który 16 kwietnia 1915 r. zastąpił generała A. von Mackensena. 
zachodni, położony na terasie nadzalewowej doliny Rawki i mniejszy, wschodni o powierzchni około $600 \mathrm{~m}^{2}$, usytuowany na stoku i krawędzi tej doliny. Jego północno-zachodnią część pokrywał gliniano-ziemny nasyp o wysokości do $2 \mathrm{~m}$, szerokości około $10 \mathrm{~m}$ i długości około $20 \mathrm{~m}$ oraz dojazdowy trakt wyłożony betonowymi płytami. Były to pozostałości elementów autostrady, której budowę rozpoczęto, lecz nie ukończono, w drugiej połowie lat siedemdziesiątych XX w. Rosły tu także gęste zagajniki i biegła ścieżka do brodu na Rawce. Ten odcinek stanowiska nie był objęty pracami eksploracyjnymi (ryc. 8). Natomiast w jego zachodniej części, w granicach obszaru określonego jako hektar E, odkryto pozostałości bardzo interesujących i nietypowych dla badań archeologicznych obiektów nieruchomych oraz materiału zabytkowego (ryc. 9).

\section{Obiekty nr 48 i 87}

Należy do nich przede wszystkim obiekt $\mathrm{nr} 48$ stanowiący resztki drewnianej konstrukcji w formie prostopadłościennej skrzyni o szerokości $240 \mathrm{~cm}$ i długości $480 \mathrm{~cm}$, tkwiące we wkopie o głębokości około $150 \mathrm{~cm}$. Skrzynię zbudowano z położonych na sobie sosnowych, nieokorowanych pni łączonych w narożnikach na zrąb i spajanych żelaznymi kotwami. Na poziomie przyziemia jej wnętrze przedzielone było trzema poprzecznymi belkami na trzy komory

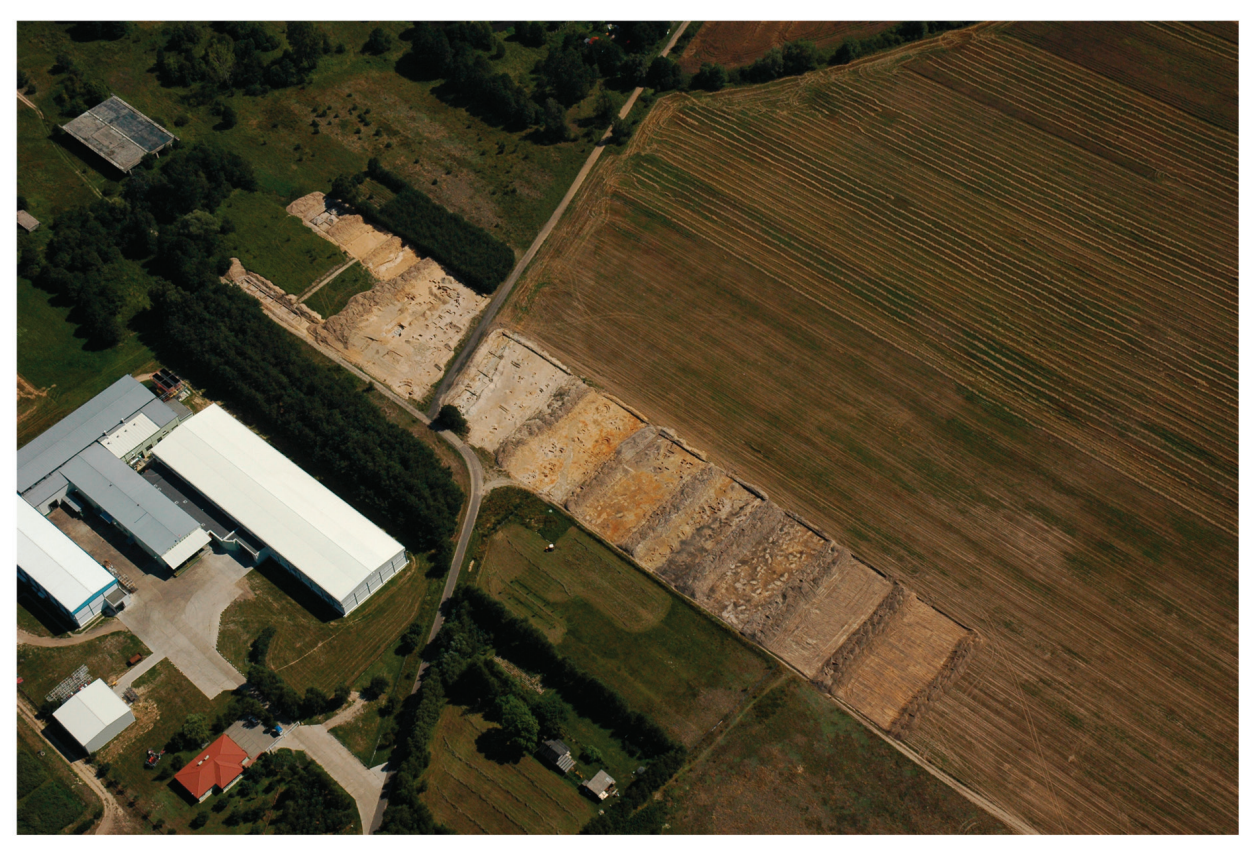

Ryc. 8. Widok z lotu ptaka stanowiska 9 w Bolimowie w trakcie badań archeologicznych (fot. W. Stępień). 


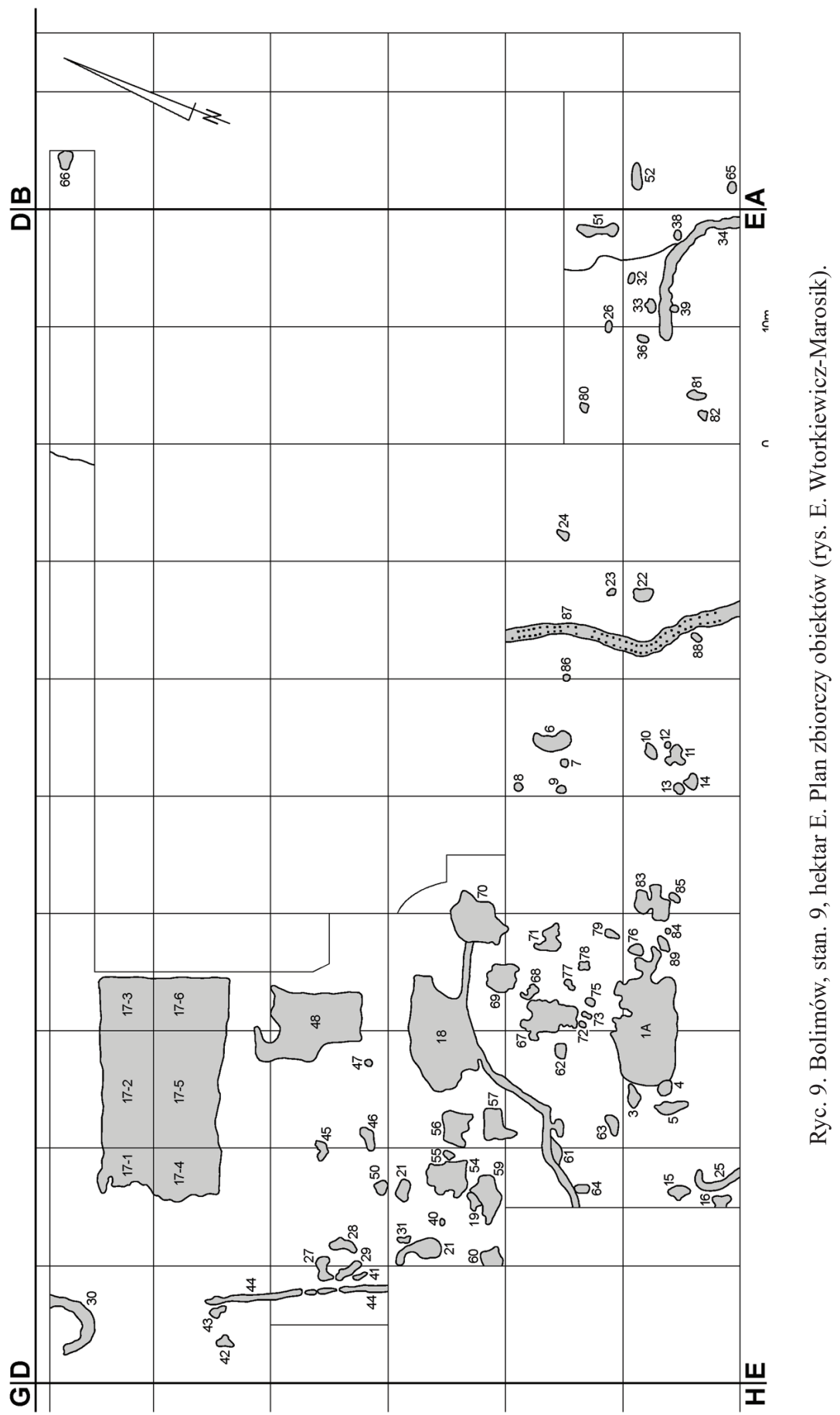


o wewnętrznych wymiarach 90 x $190 \mathrm{~cm}$ i jedną 110 x $190 \mathrm{~cm}$. Belki oraz dwa słupy wbite tuż przy wschodniej ściance skrzyni wzmacniały całą konstrukcję. Nie stwierdzono śladów ścianek działowych oraz podłogi lub wzmocnienia podłoża (ryc. 10, 11). W wypełnisku wkopu znajdowało się jedynie kilka dużych strzępów smołowanej papy, pokrywającej najpewniej jego zadaszenie oraz kilka fragmentów glinianych naczyń. W północnym profilu dołu zawierającego tę konstrukcję widoczne były na wysokości około $50 \mathrm{~cm}$ od dna ślady dochodzącego do niej innego obiektu (ryc. 12). Nie udało się go rozpoznać ze względu

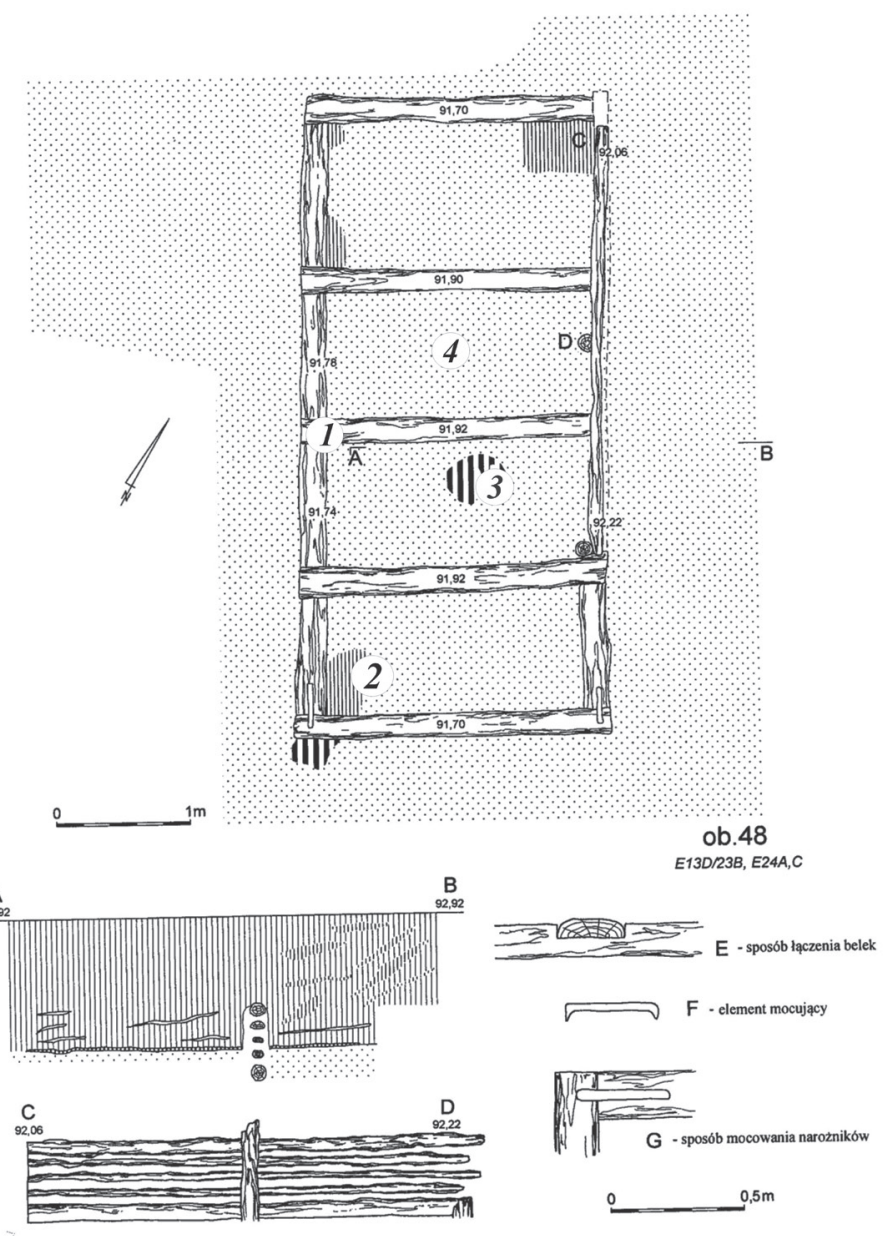

Ryc. 10. Bolimów, stan. 9, obiekt nr 48.

Legenda: 1. Drewno; 2. Spalone drewno; 3. Ciemnobrunatna próchnica; 4. Żółty piasek (rys. E. Wtorkiewicz-Marosik). 

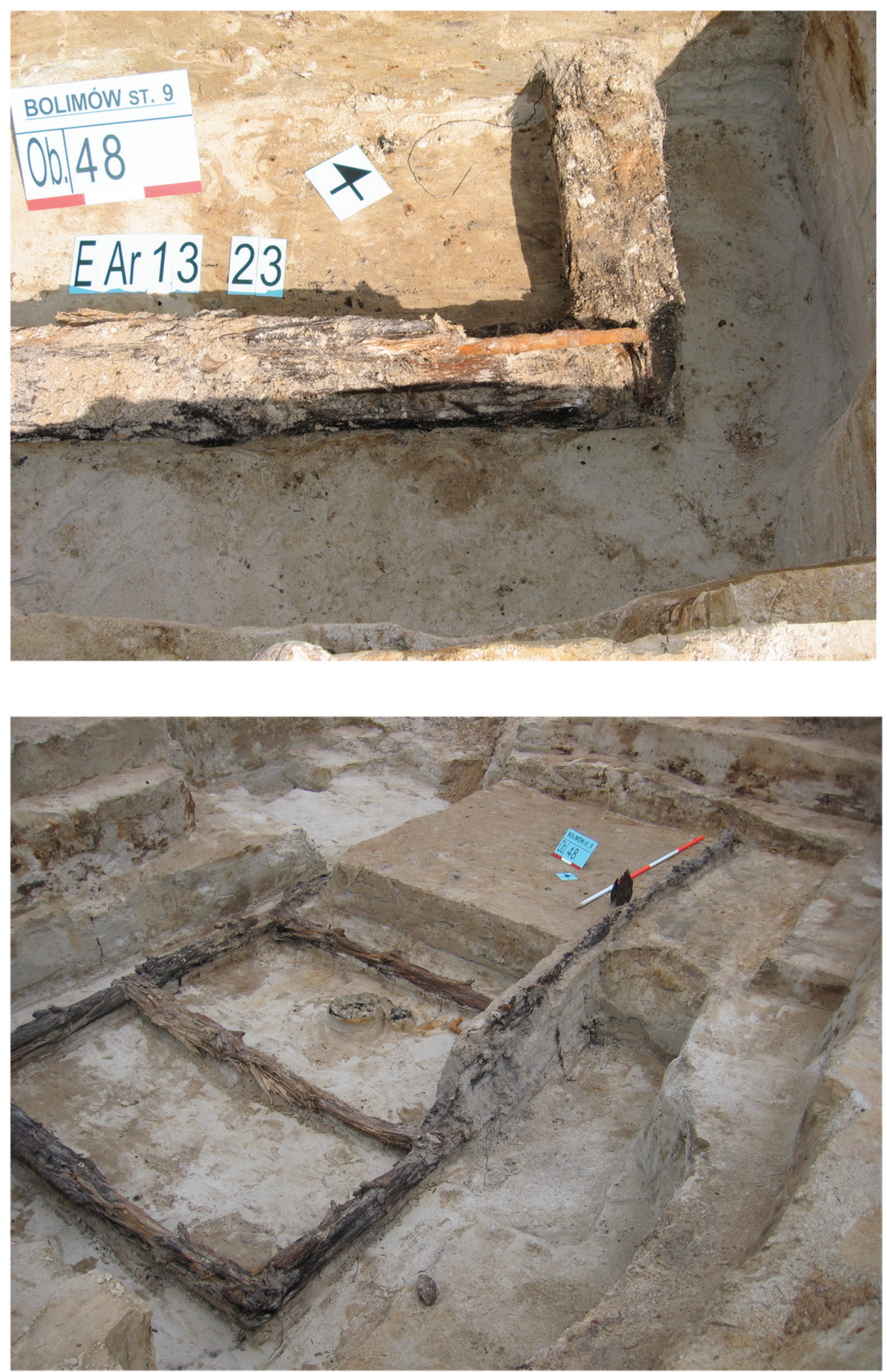

Ryc. 11. Bolimów, stan. 9, obiekt nr 48 (fot. P. Świątkiewicz). 


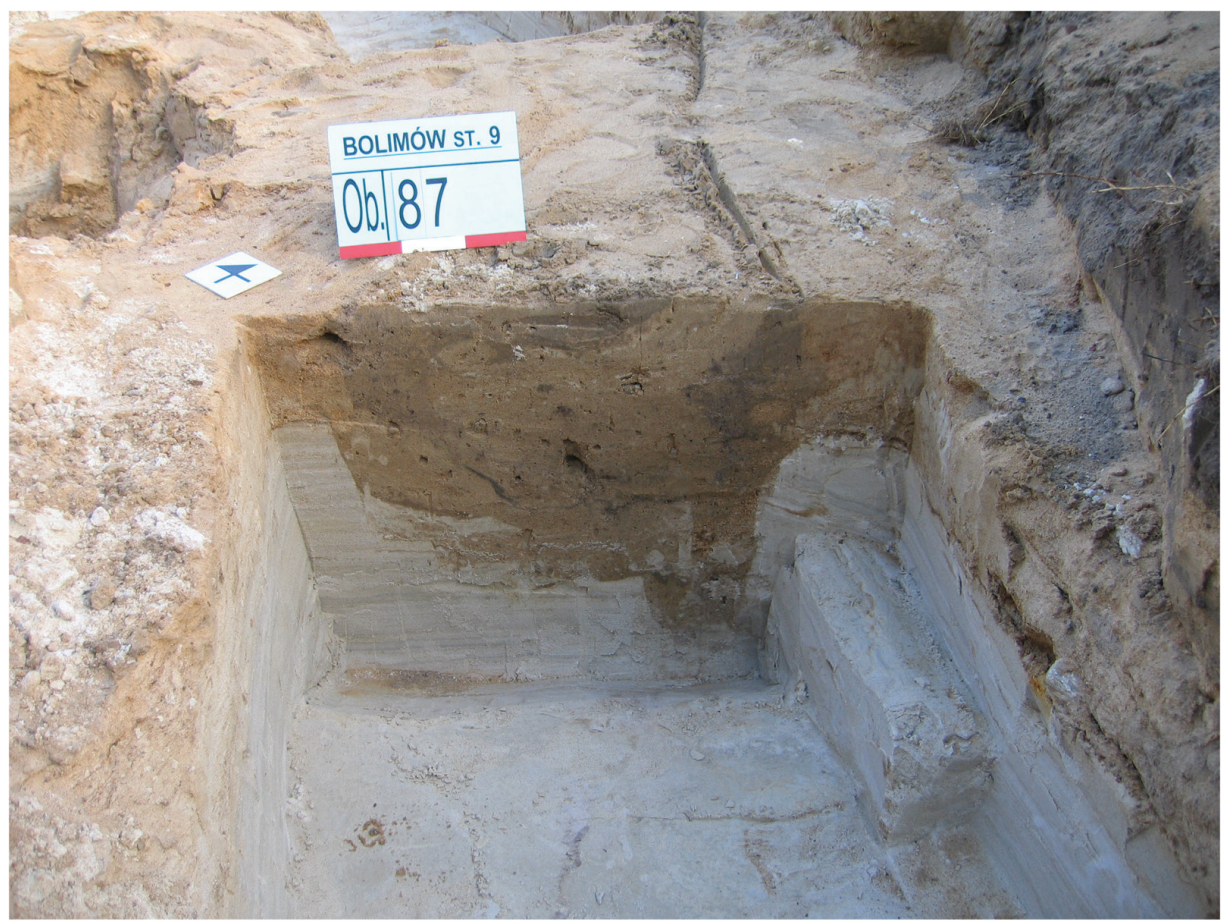

Ryc. 12. Ślady dojścia do obiektu nr 48 (obiekt nr 87) (fot. P. Świątkiewicz).

na zalegający na jego stropie gliniany nasyp pod nieukończoną autostradę. Sądzimy, że jest to końcowy odcinek innego dzieła budowlanego odkrytego między południowym skrajem nasypu i wykopu archeologicznego. Tworzył go wykop w formie rowu (obiekt nr 87) o uchwyconej długości $2000 \mathrm{~cm}$ i szerokości 40-50 cm biegnący z północy na południe, czyli wzdłuż skraju terasy. Jego obydwie ściany wzmacniane były 62 palikami rozmieszczonych parami w równych odstępach. Pozostały po nich dołki posłupowe (ryc. 13, 14; Świątkiewicz 2011, ryc. 18). W rowie nie odkryto ruchomego materiału zabytkowego.

Do zidentyfikowania pierwotnego kształtu tych obiektów można posłużyć się źródłami ikonograficznymi. Chodzi o fotografie przedstawiające inżynieryjne dzieła armii cesarsko-niemieckiej na wschodnioeuropejskich polach bitewnych I wojny światowej, w tym przeznaczone do działań bojowych okopy i umocnione schronienia podobne np. do mocno wgłębionej w grunt ziemianki z pozycji 8. Pułku Landwehry nad Bzurą, widocznej na jednym ze zdjęć w książce S. Kalińskiego (2010: 69) ${ }^{12}$. Różnego rodzaju prowizoryczne

${ }^{12}$ Fot. dolna: „Żołnierze 8. Pułku Landwehry z Dywizji Westerhagen przed ziemianką nad Bzurą, luty 1915”. Zdjęcie z kolekcji autora. 


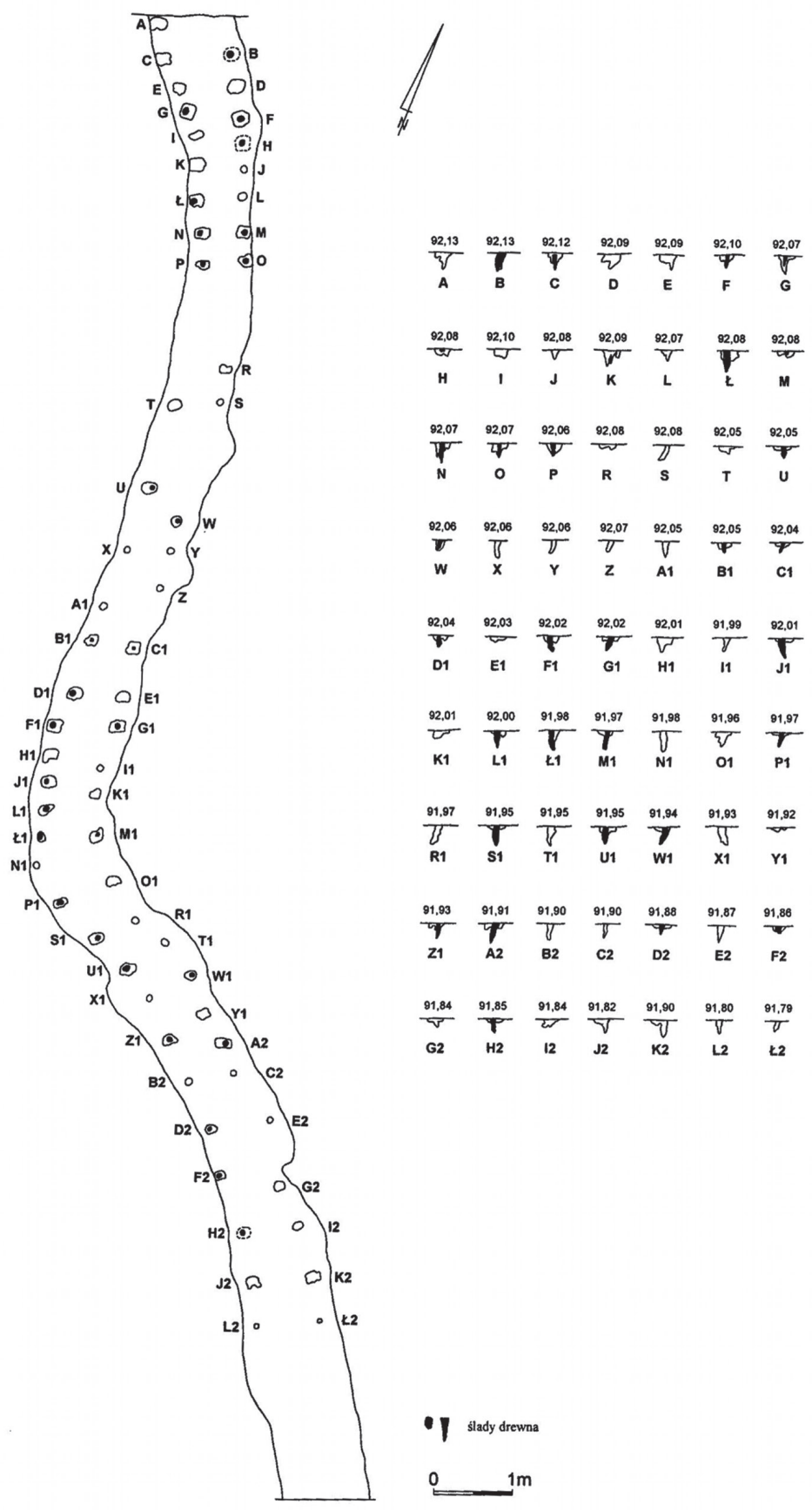

Ryc. 13. Bolimów, stan. 9, obiekt nr 87 (rys. E. Wtorkiewicz-Marosik). 

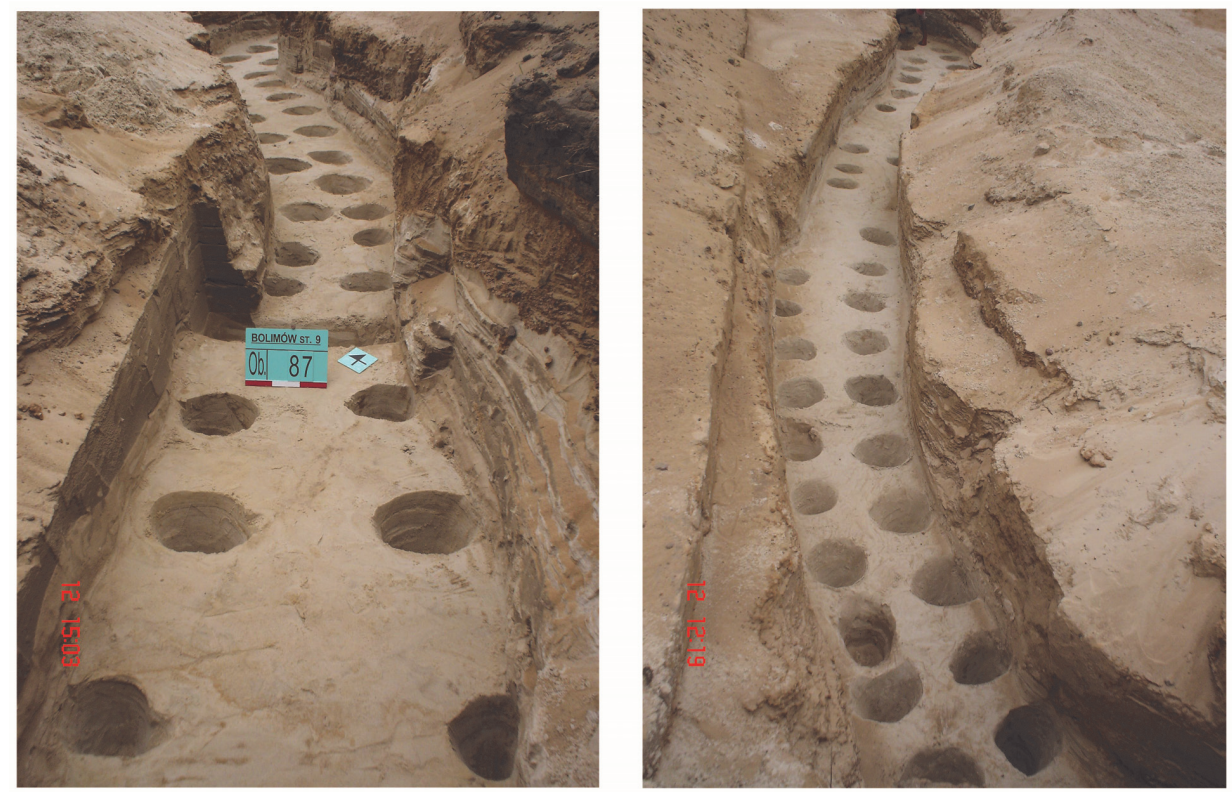

Ryc. 14. Bolimów, stan. 9, obiekt nr 87 (fot. P. Świątkiewicz).

budynki służące do odpoczynku żołnierzy oraz transzeje wykonywane były także przez 21. Pułk von Borcke (ryc. 15, 16). W świetle tych analogii nie ulega wątpliwości, że w obrębie stanowiska 9 wzniesiono również drewniane, kryte papą ziemiankowe schronisko (schron), do którego prowadziło głębokie dojście w postaci rowu - transzei ze ścianami wzmacnianymi drewnianą konstrukcją kotwiczoną palikami.

Pewną trudność sprawia określenie rzeczywistej funkcji schronu. Z uwagi na swe położenie na dalekim zapleczu frontu nie był on włączony w system stricte bojowych umocnień. Teoretycznie mogłoby w nim odpoczywać 8-12 żołnierzy tworzących np. drużynę (Gruppe/Truppe) ${ }^{13}$ lub sztab pododdziału mniejszego niż Unterstab 3. batalionu pułku von Borcke złożony z ośmiu podoficerów i ośmiu żołnierzy uwiecznionych na tle podobnej budowli na jednej z fotografii (ryc. 17). Trudno jednak zrozumieć sens zbudowania w miejscu odległym od pola walki i nie narażonym na bezpośrednie zagrożenie, pomieszczenia o solidnej konstrukcji, przypominającego ciasną komorę bez ogrzewania, z której jedynie ludzka głowa wystaje ponad poziom gruntu. W takich miejscach wznosi

${ }^{13}$ Jednak w tej fazie Wielkiej Wojny struktura organizacyjna armii niemieckiej w zasadzie nie obejmowała tak małych pododdziałów i zaczynała się od plutonu (der Zug) sformowanego z 40-60 żołnierzy. Oczywiście, nie wykluczało to tworzenia mniejszych grup do specjalnych zadań. 


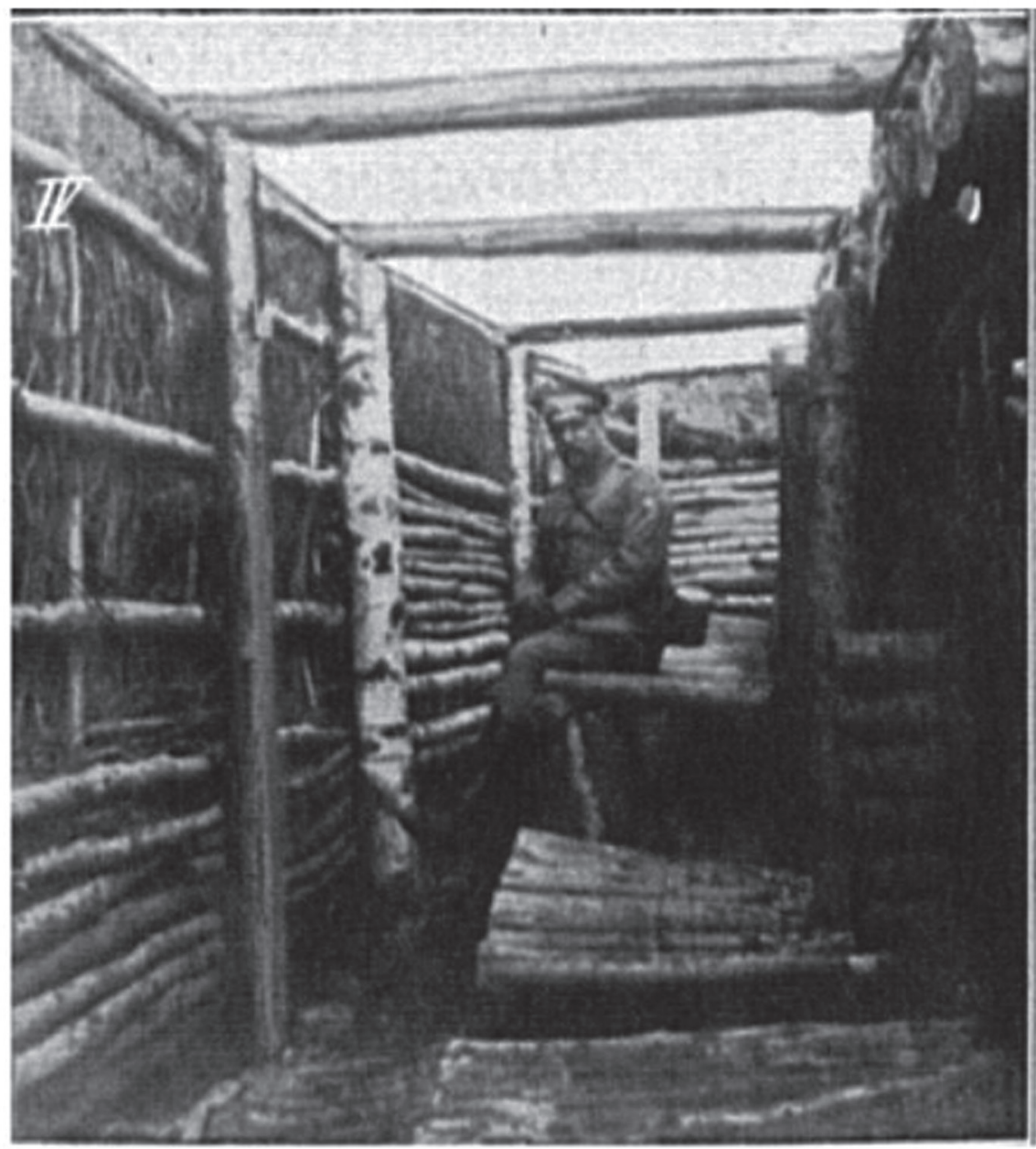

Ryc. 15. Kapitan hrabia von der Baudissin w okopie pod Konstancą, styczeń 1917 r. (Kriegsgeschichte..., Tafel 17/IV).

się raczej naziemne budowle, podobne np. do prowizorycznych chat z wysokimi wejściami, wzniesionych $\mathrm{w}$ innym obozie pod Bolimowem i uwiecznionych na fotografii także opublikowanej przez S. Kalińskiego (2010: 69) ${ }^{14}$. Dlatego sądzimy, że opisana tu konstrukcja wraz z transzeją nie stanowiła miejsca relaksu i noclegu żołnierzy, lecz element tyłowej, zapasowej rubieży obronnej broniącej np. dojścia do brodu na Rawce lub pełniącej funkcję refugialnego schronienia, użytkowanego jedynie (albo w ogóle) w okresie szczególnego zagrożenia,

\footnotetext{
${ }^{14}$ Fot. górna: „Ziemianki w lesie w okolicy Bolimowa”. Zdjęcie z kolekcji autora.
} 


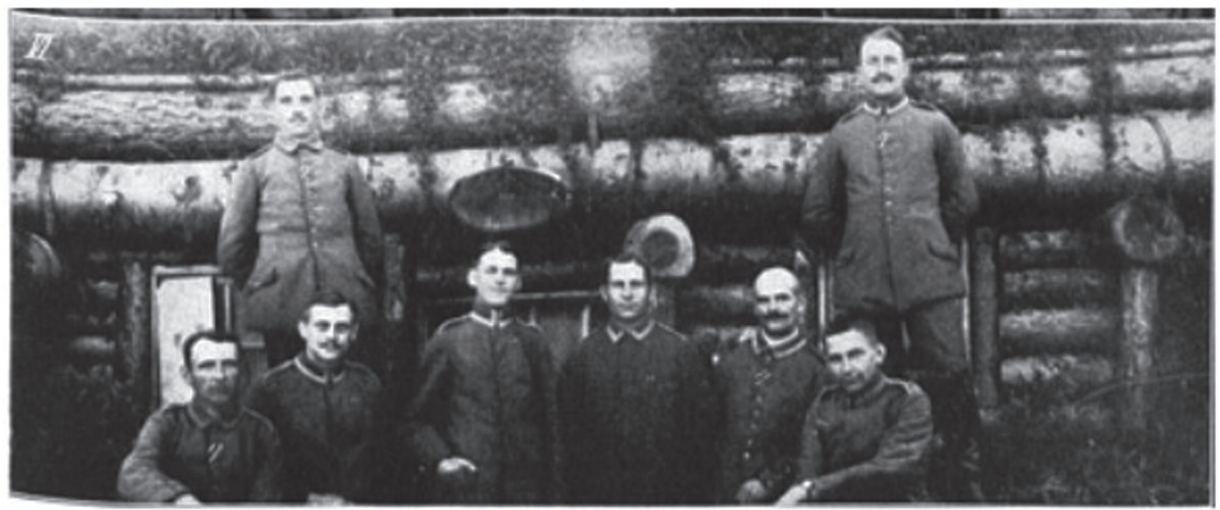

Ryc. 16. Grupa żołnierzy 21. pułku przed polową kwaterą, Kurlandia listopad 1917 r. (Kriegsgeschichte..., Tafel 20/IV).

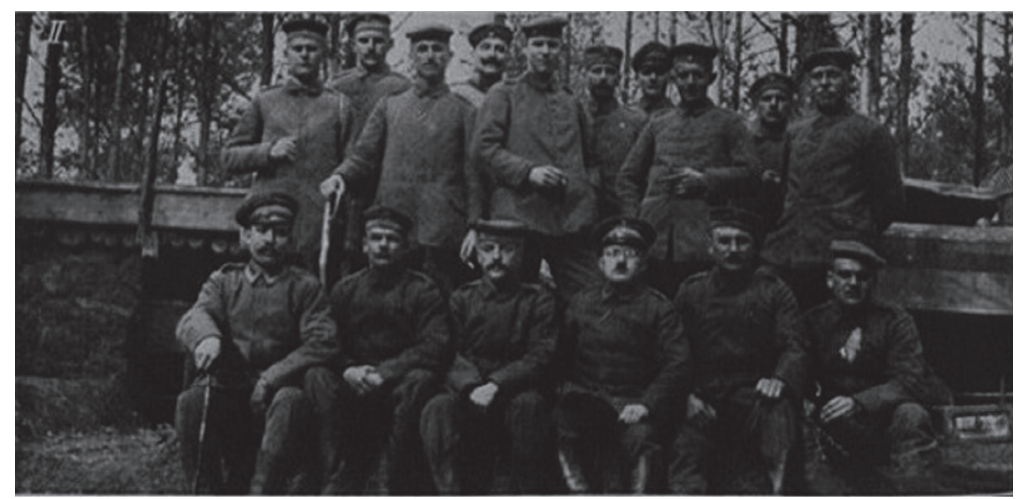

Ryc. 17. Unterstab I./21 (Kriegsgeschichte..., Tafel 17/II).

np. artyleryjskiego ostrzału Rosjan. Hipotezę tę potwierdza brak w jego wnętrzu ruchomego materiału zabytkowego, poza znajdującym się na wtórnym złożu.

\section{Obiekty nr 18 i 70}

Na południowy zachód od linii schron - transzeja odkryto liczne jamy o zróżnicowanej charakterystyce. Należy do nich przede wszystkim zespół nr 18 i 70 złożony z wkopów o wymiarach odpowiednio 100 x $200 \mathrm{~cm}$ i głębokości co najmniej $50 \mathrm{~cm}$ oraz 225 x $340 \mathrm{~cm}$ i głębokości $75 \mathrm{~cm}$, połączonych rowem o szerokości około $30 \mathrm{~cm}$ i głębokości około $50 \mathrm{~cm}$ kontynuującym się $\mathrm{w}$ kierunku południowo-wschodnim, poza badany odcinek. W obiekcie nr 70 znaleziono bagnet wzór SG-98 Neue Art. do karabinu Mauser 98 (ryc. 18; 


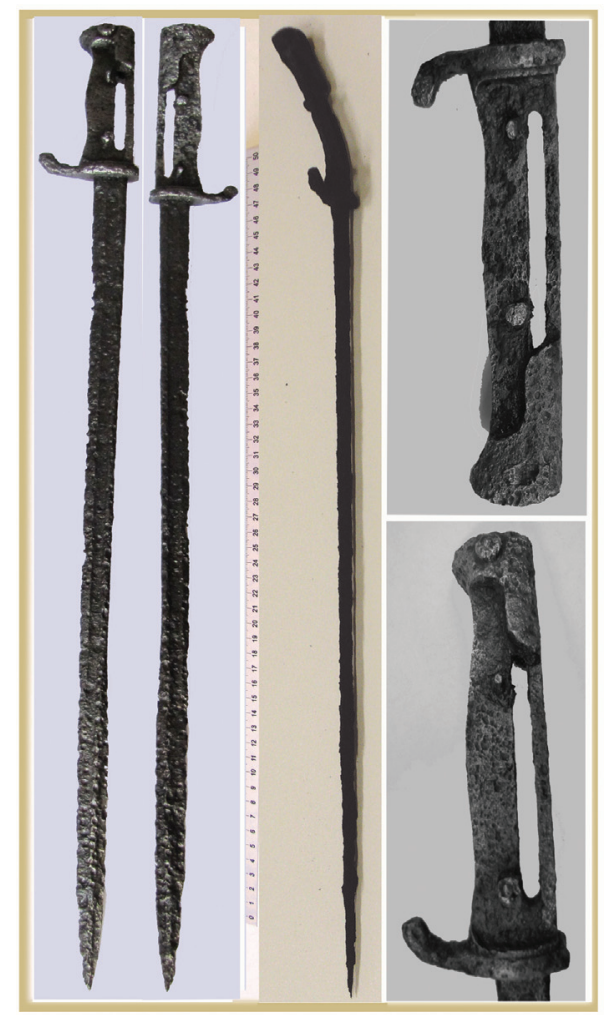

Ryc. 18. Bagnet wz. 98 z obiektu nr 70 przed konserwacją (pole środkowe) i po konserwacji (pola boczne) (fot. P. Świątkiewicz).

Królikiewicz 1997: 268-274; Surer: nr 377) i fragment skórzanej portmonetki z monetą o nominale $1 / 24$ talara Fryderyka Wilhelma II z 1782 roku $^{15}$. Z obiektu nr 18 pozyskano kilka fragmentów naczyń glinianych i szklanych, m.in. prostopadłościenną szklaną butelkę z napisem: 100 na dnie. Znaczne rozmiary oraz regularne kształty tego zespołu mocno przypominają fragment okopu (z wysuniętymi stanowiskami strzeleckimi?), jednak nieporównywalnego np. $\mathrm{z}$ dobrze umocnionym, ziemiankowym schronem. Naszym zdaniem, była to ćwiczebna transzeja powstała $\mathrm{w}$ trakcie i służąca do przeprowadzania specjalistycznego (fachgemäß), pozafrontowego doskonalenia umiejętności żołnierzy, w tym budowania i korzystania z ukrytych pozycji strzeleckich.

\footnotetext{
${ }^{15}$ Ekspertyzę numizmatyczną monet z badań w Bolimowie wykonała E. Hanc-Maik (Hanc-Maik 2010).
} 


\section{Zabytki z obiektów nr 19, 54, 57, 63, 67 i 68}

W prostokątnej jamie $\mathrm{nr} 57 \mathrm{o}$ wymiarach 250 x $235 \mathrm{~cm}$ z trójkątnym aneksem i głębokości $30 \mathrm{~cm}$ odkryto pozostałości paleniska z resztkami kości domowego ptactwa, skórzanego obuwia i portmonetki z ośmioma monetami 5. i 10. fenigowymi Cesarstwa Niemieckiego z lat 1891-1914 oraz szyjkę butelki szklanej. W stropie wieloczłonowej jamy $\mathrm{nr} 67$ o ogólnych wymiarach 320 x $500 \mathrm{~cm}$ znajdowały się: mosiężny orzeł wzór M1895 z monogramem „FR” (Füssilier Regiment) z hełmu typu Pickelhaube wzór 1905/06, noszonego przez żołnierzy pruskich liniowych pułków piechoty (ryc. 19; Świątkiewicz 2011, ryc. 19), fragment stołowego noża (tabl. I: a) oraz szklana butelka. W obiekcie tym znaleziono również niezużyte pociski karabinowe i bliżej niezidentyfikowane elementy uzbrojenia, wobec czego z braku nadzoru saperskiego zrezygnowano z jego całkowitej eksploracji. W sąsiadującej z nim prostokątnej jamie nr 68 o wymiarach $90 \times 110 \mathrm{~cm}$ znaleziono fragmenty naczyń szklanych i glinianych oraz żelazny przedmiot w postaci tulejki z haczykowatymi wypustkami. Jest to prawdopodobnie okucie tyczki stosowane przez armię cesarską jako „wieszak” (podpora) pod linie „telefoniczne na tyczkach” (nie „na rososzkach”) lub być może improwizowany „wieszak do potykaczy” (ryc. 20). Wieszaki takie wykorzystywano do mocowania polowych linii telefonicznych „na tyczkach”, a także, czasami, w skrytych przejściach przez własne zasieki, nieregulaminowo używano ich, przy ułatwiających żołnierskie życie różnych pracach obozowych (Podręcznik...: 797). Z kolei w kwadratowym obiekcie $\mathrm{nr} 54$ o długości boków $280 \mathrm{~cm}$ odkryto, poza dwoma fragmentami naczyń, również łyżkę żelazną (tabl. I: d). W obiekcie nr 63 znajdowała się, poza kilkoma fragmentami naczyń, żelazna podkówka wojskowego buta (tabl. I: e), a w humusie zalegającym w pobliżu tych obiektów także trzy guziki mundurowe armii cesarsko-niemieckiej (tabl. I: c). Intrygujący zabytek pochodzi

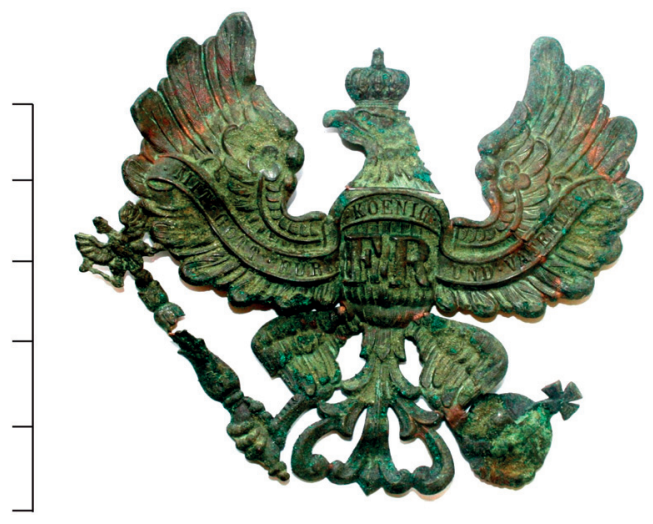

Ryc. 19. Orzeł z hełmu typu Pickelhaube (fot. P. Świątkiewicz). 


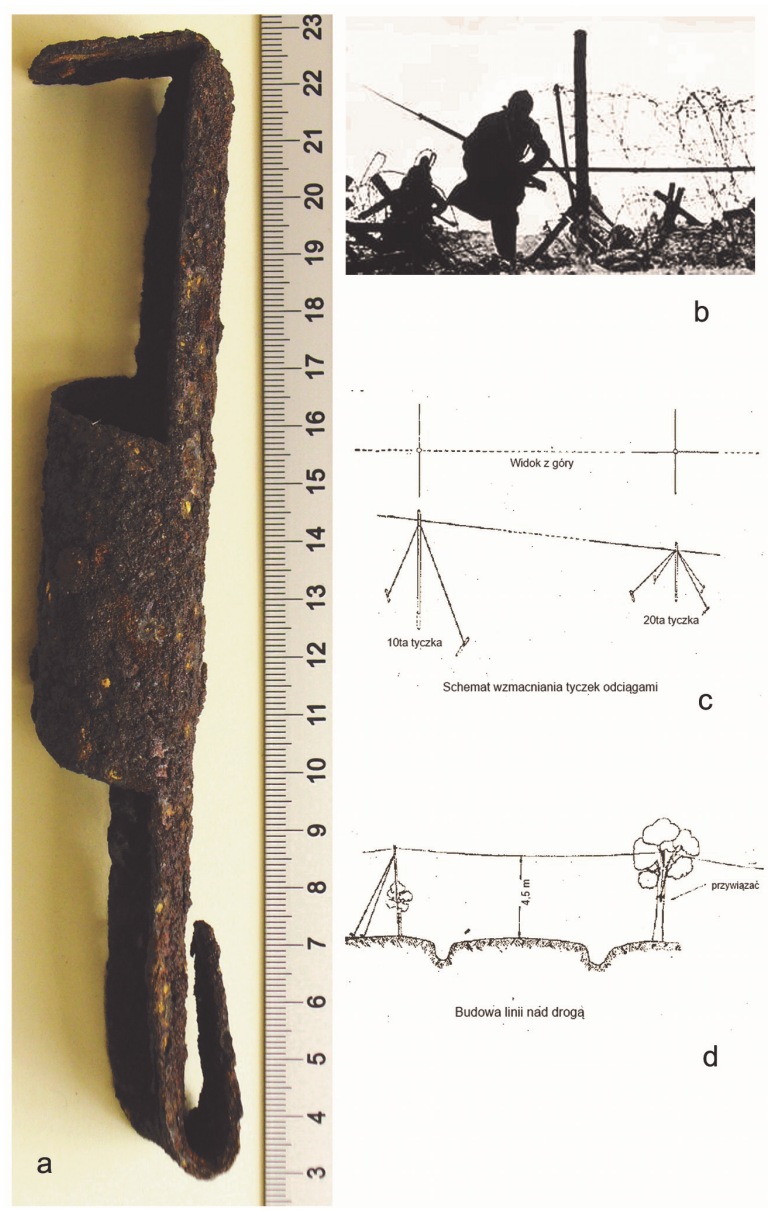

Ryc. 20. Okucie podpory pod linie telefoniczne(?) (fot. K.E. Natkański).

z wieloczłonowego obiektu nr 19 wymiarach 90 x $90 \mathrm{~cm}$ i lejowatym przekroju o głębokości $70 \mathrm{~cm}$. Jest to dno szklanej butelki z literami pisanymi cyrylicą: МФ 1/20B (ryc. 21: b).

\section{Pozostałości zagrody (obiekty nr 1, 1A, 1B, 1C)}

W bezpośrednim sąsiedztwie tego zespołu odkryto relikt chaty o gliniano-kamiennej konstrukcji, z zawaliskiem pieca i komina (obiekt nr 1), studnię o kamiennej cembrowinie (obiekt nr 1A) oraz kilka dołów śmietnikowych (obiekty nr 1B, 1C, 56 i 83; ryc. 22; Świątkiewicz 2011, ryc. 11). Chata zachowała się w postaci czworobocznego płata zbitej gliny o wymiarach 580 x $600 \mathrm{~cm}$ i gru- 

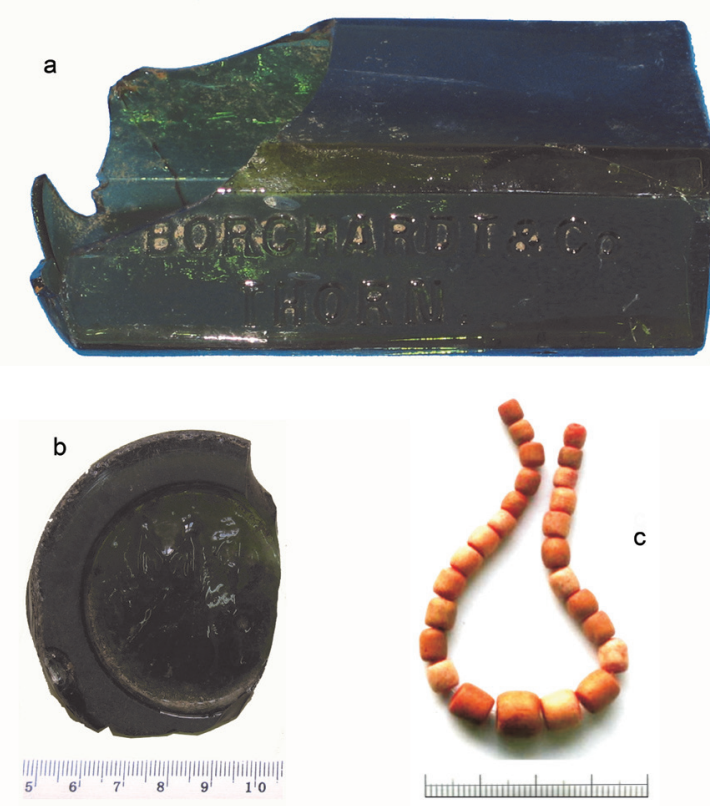

Ryc. 21. a. Butelka z obiektu nr 83; b. Dno butelki z obiektu nr 19; c. Sznur korali z obiektu nr 83 (fot. P. Świątkiewicz).

bości 40-50 cm z kamieniami o zróżnicowanej średnicy ułożonymi w trzech - czterech warstwach w południowo-wschodniej części obiektu, w sąsiedztwie rumoszu ceglanego i warstwy spalenizny świadczącej o istnieniu pieca z kominem(?). Nie był to budynek podpiwniczony, a jego podłogę tworzyła polepa. Nie zachowały się ślady pozwalające odtworzyć konstrukcję jego ścian, ani tym bardziej zadaszenia, choć sądzić można, że przynajmniej częściowo zbudowano go z gliny (ryc. 23, 24; Świątkiewicz 2011; ryc. 12). Z tego obiektu pozyskano m.in. liczne fragmenty naczyń glinianych i szklanych oraz zabytki metalowe ${ }^{16}$. Wśród nich na specjalne wyróżnienie zasługują m.in. sprężynowy zaczep - karabińczyk (tabl. I: f), łódka do karabinu Mauser (tabl. I: b), ułamki dwóch butelek o kolistych, mocno wklęsłych dnach charakterystycznych dla butelek do win musujących oraz część podstawy mosiężnej kokardy rosyjskiej czapki oficerskiej wz. 1907 z wytłoczonym napisem: СЛАВA (SŁAWA) (ryc. 25). Tłoczony napis jest zapewne sygnaturą znanej moskiewskiej firmy produkującej elementy umundurowania, podobnie jak kilka innych sygnatur rozpoznanych na elementach uzbrojenia z pól bitewnych w Polsce np.: L.KRANC Warszawa (czasem tylko

\footnotetext{
${ }^{16}$ Bardziej szczegółowy opis ruchomego materiału zabytkowego (Świątkiewicz 2011: 197-200).
} 


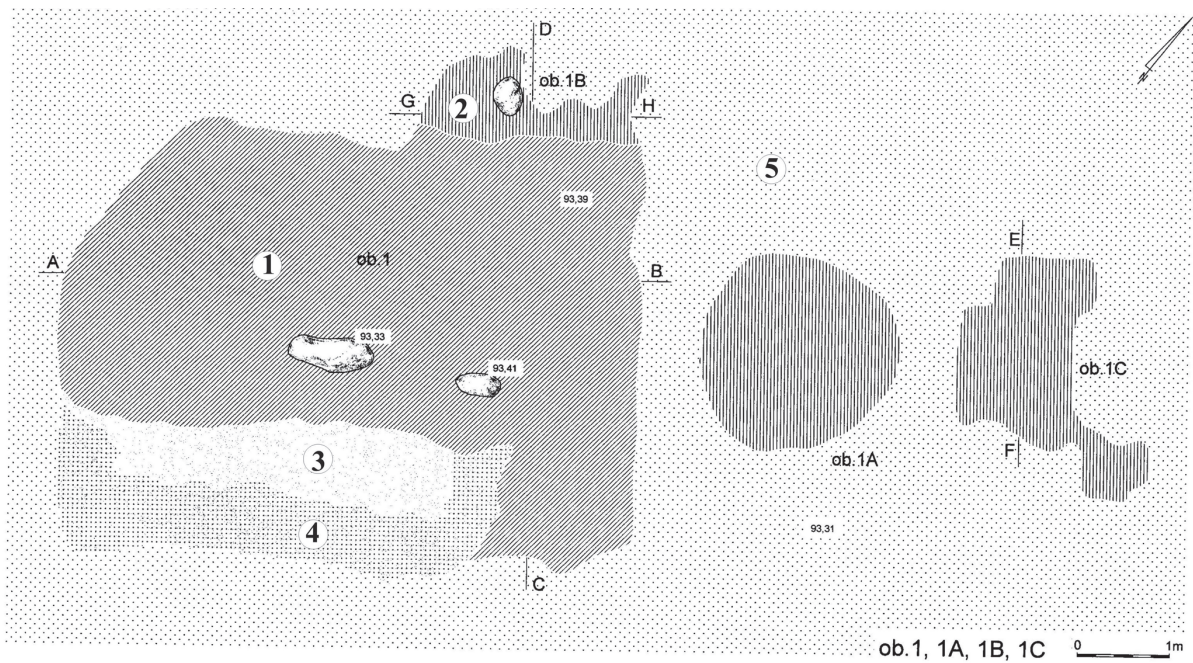

Ryc. 22. Pozostałości zagrody z przełomu XIX/XX wieku. Obiekt nr 1 - domostwo; Obiekt nr 1A - studnia; Obiekty nr 1B, 1C - doły śmietnikowe. Legenda: 1. Jasnobrunatna glina; 2. Ciemnobrunatna próchnica z piaskiem; 3. Jasnoszary piasek; 4. Brunatno-szary piasek (rys. E. Wtorkiewicz-Marosik).

KRANC), ШТЭТИНИН - Moskwa czy MELCHIOR (miejscowość nieokreślona) (Dubrowska 1997: 125-144) ${ }^{17}$. Na wschód od niego odkryto pozostałości studni (obiekt nr 1A) o wewnętrznej średnicy 90-100 cm i zachowanej wysokości $60 \mathrm{~cm}$ zbudowanej z kamieni eratycznych bez zastosowania lepiszcza (ryc. 26, 27; Świątkiewicz 2011, ryc. 13). W pobliżu domostwa wystąpiły liczne mniejsze i większe jamy o cechach typowych dla tzw. dołów śmietnikowych. Do największych należał trapezowaty w przekroju obiekt nr 83 o wymiarach $350 \times 240 \mathrm{~cm}$ i głębokości około $50 \mathrm{~cm}$ przylegający od wschodu do chaty. Wśród odkrytego w nim bogatego materiału zabytkowego wyróżnić trzeba 27 beczułkowatych, koralowych paciorków pochodzących prawdopodobnie z kobiecego naszyjnika (ryc. 21: c) oraz urozmaicony zestaw butelek szklanych, w tym prawie całą, prostopadłościenną butlę z ciemnozielonego szkła i napisem: BORCHARDT \& Co THORN (ryc. 21: a; Świątkiewicz 2011, ryc. 15). Jest to najprawdopodobniej nazwa toruńskiej firmy zajmującej się destylowaniem i handlem spirytualiami. Natomiast w zawartości jamy 1B o głębokości $40 \mathrm{~cm}$, długości około $240 \mathrm{~cm}$ i szerokości $80 \mathrm{~cm}$ wyróżniały się fragmenty płytkiego talerza fajansowego z granatowym napisem: ROYAL STONE CHINA FREUDENREICH oraz pięć

\footnotetext{
${ }^{17} \mathrm{~W}$ publikacji zabytek ten określono omyłkowo jako okucie z niemieckiej czapki (Świątkiewicz 2011: 199).
} 


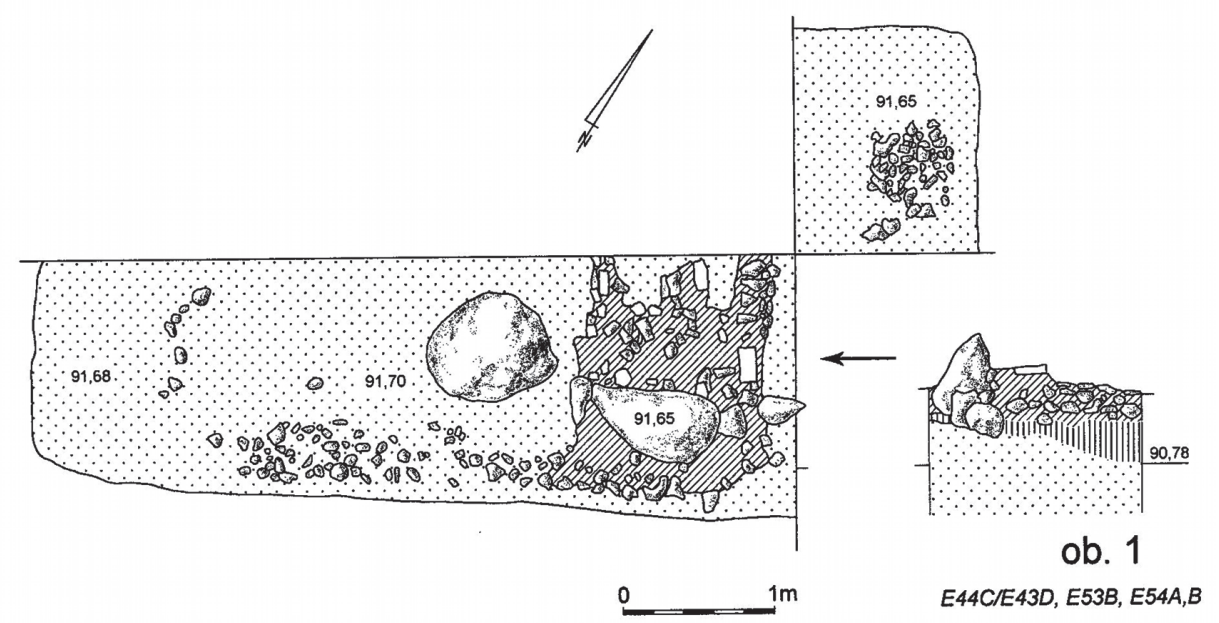

Ryc. 23. Pozostałości chaty (rys. E. Wtorkiewicz-Marosik).

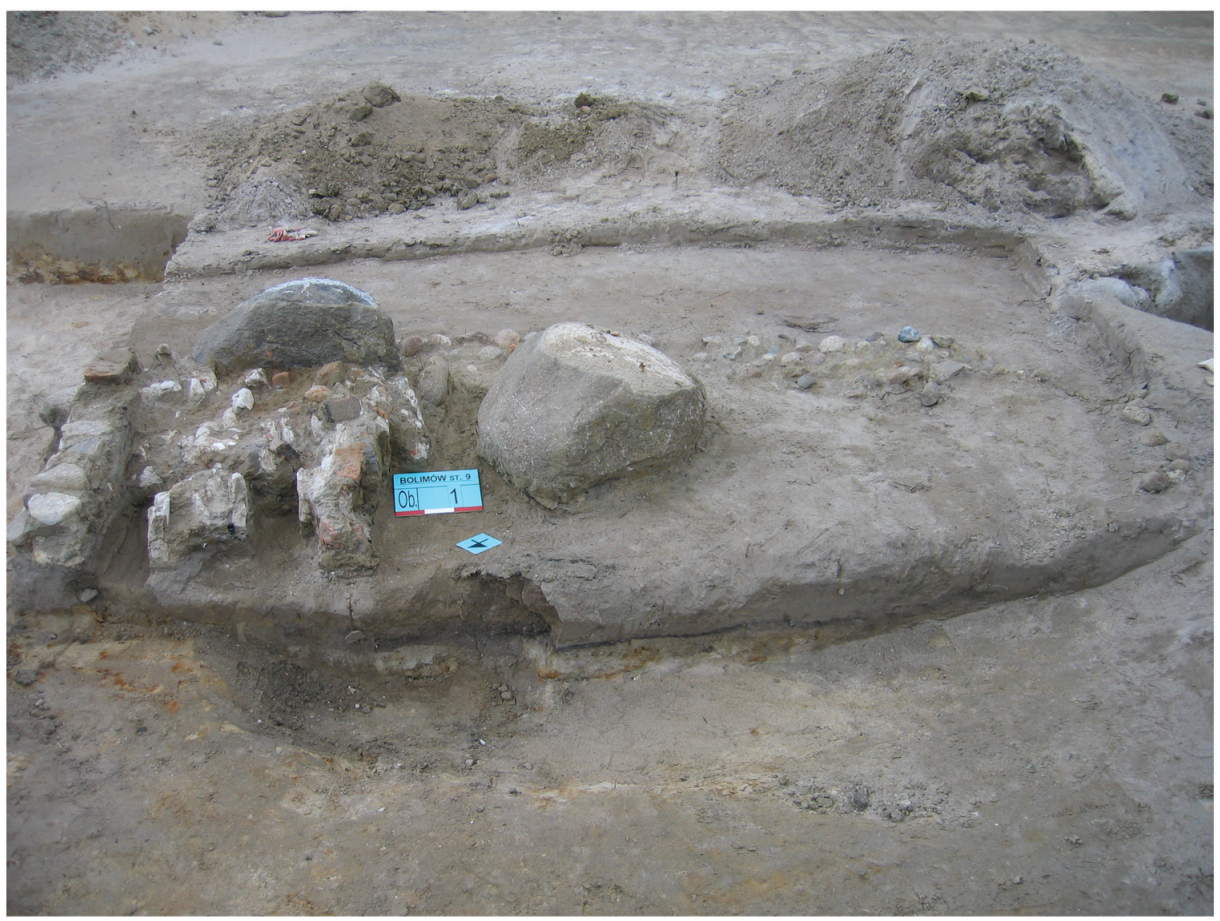

Ryc. 24. Pozostałości chaty (fot. P. Świątkiewicz). 


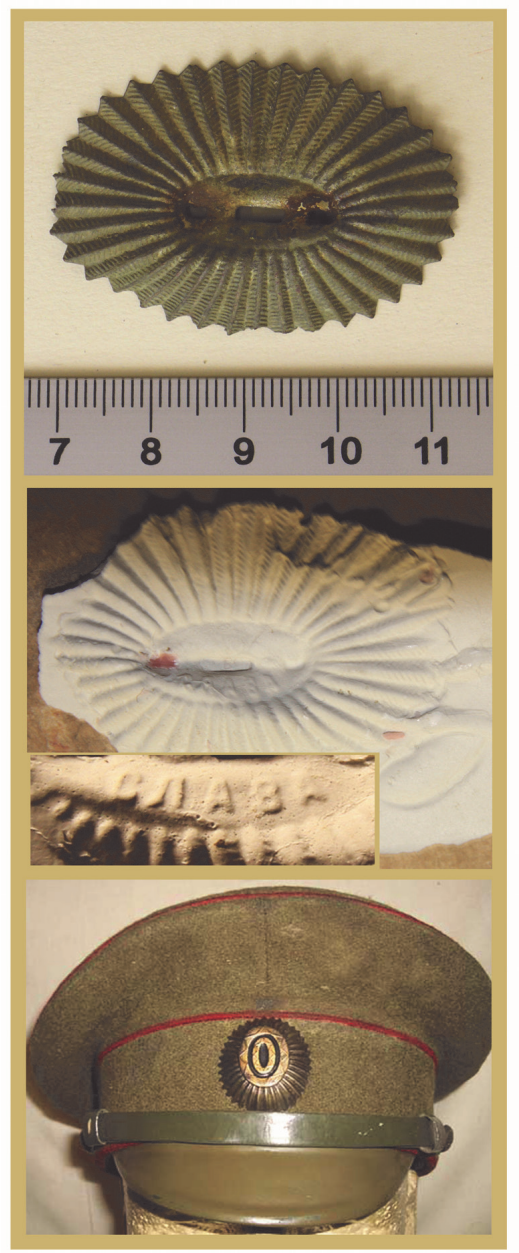

Ryc. 25. Podstawa „kokardy” z rosyjskiej czapki z obiektu nr 1 (fot. K.E. Natkański).

fragmentów płytkich talerzy fajansowych z kwiatową, zielono-amarantowo-niebieską malaturą ( 2 talerze). Pierwszy z talerzy wykonano z pewnością, a drugi prawdopodobnie w wytwórni fajansów założonej w Kole przez Józefa Freudenreicha w 1842 r. i funkcjonującej do 1939 r. Malowane wzory kwiatowe zaczęto stosować w jej wyrobach od lat osiemdziesiątych XIX w. (Starzewska, Jeżewska 1978: 71-72).

Sądzimy, że zespół ten stanowi pozostałość funkcjonującego tu na przełomie XIX i XX wieku gospodarstwa wiejskiego charakteryzującego się względnie wysokim standardem wyposażenia. Materiał zabytkowy pozwala datować do- 

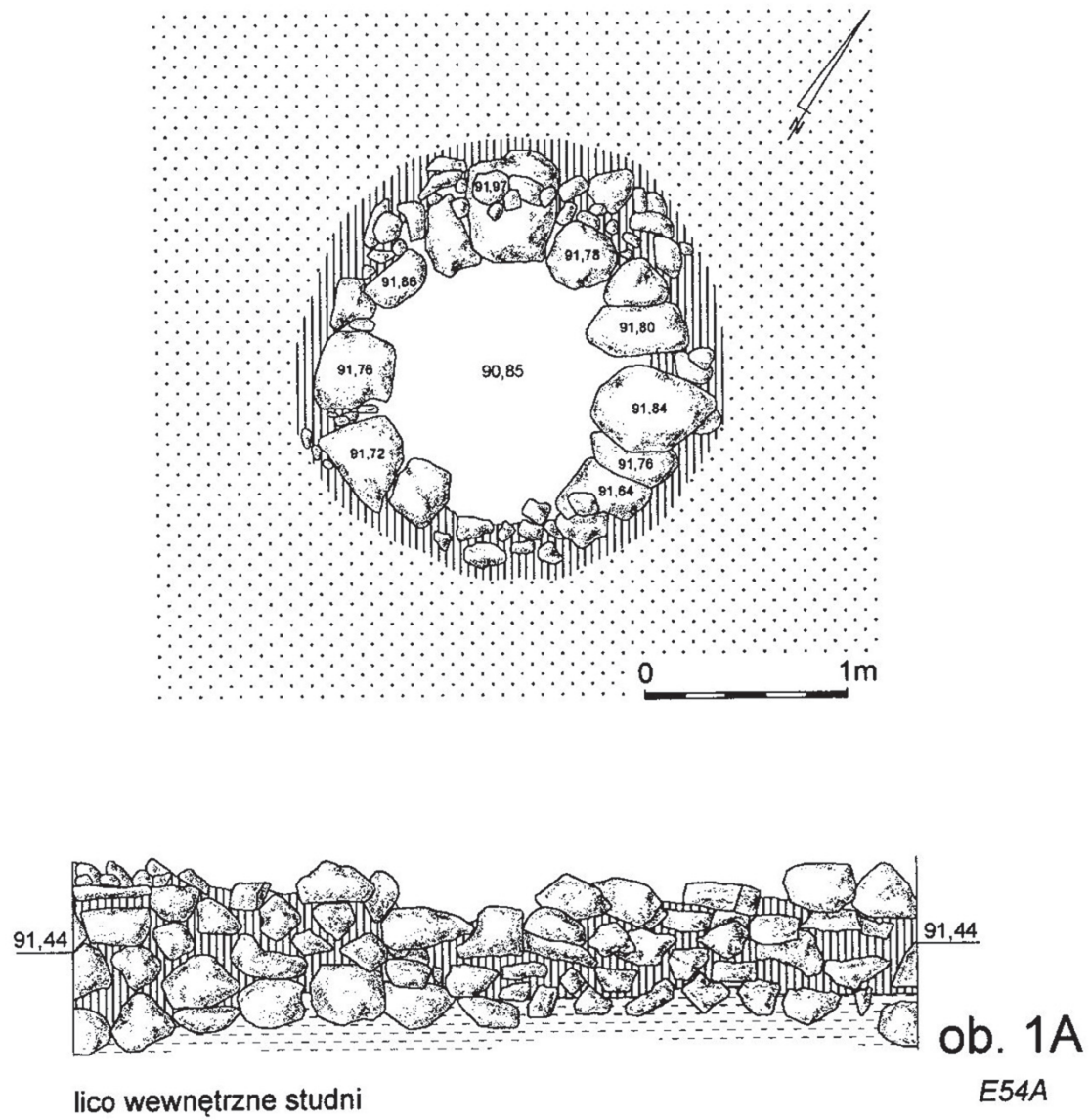

Ryc. 26. Studnia (rys. E. Wtorkiewicz-Marosik).

mostwo na 2. połowę XIX - 1. połowę (lata 20.?) XX wieku. Chronologię zagrody można także ustalić korzystając ze źródeł kartograficznych. Na niemieckiej mapie zatytułowanej Skierniewice F-34, opracowanej w oparciu o ustalenia topograficzne z lat 1884-1886, naniesiona jest droga od Bolimów - Ziemiary określona jako Ortsverbindungsweg ohne Seitengräben (ryc. 28) ${ }^{18}$, natomiast brakuje na niej opisanego wyżej budynku, choć przy wschodnim poboczu południowego, rozwidlającego się krańca tej drogi naniesiono trzy zagrody tworzące

\footnotetext{
${ }^{18}$ Jest to wycinek mapy Karte des westlichen Russland w skali 1:100 000 zredagowanej przez kartografów niemieckich i wydanej w $1915 \mathrm{r}$. na potrzeby armii w oparciu o mapy w skali 1:84 000 (tzw. dwuwiorstówki), opracowane z kolei na podstawie map w skali 1:21 000 (tzw. półwiorstówki) zachodnich rubieży imperium carskiego sporządzonych w latach 1884-1886.
} 


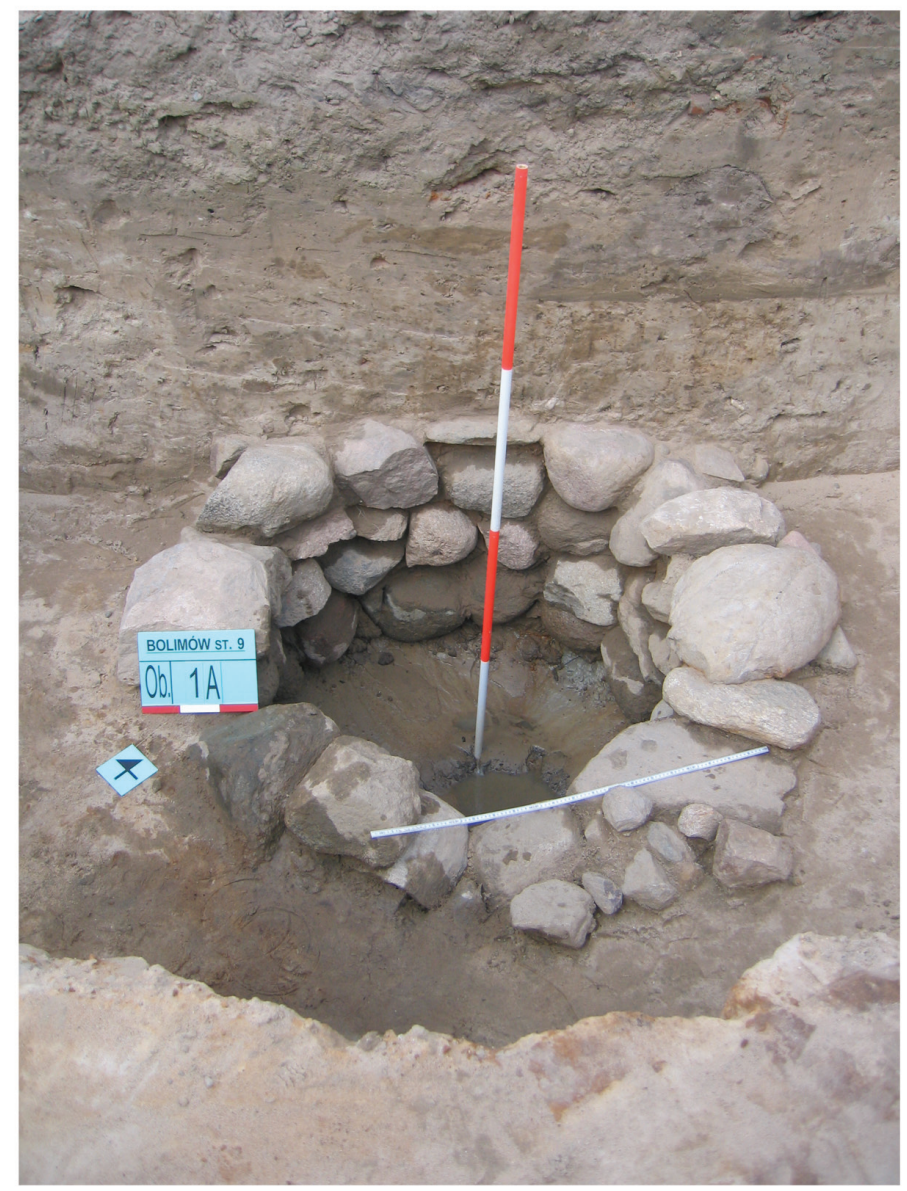

Ryc. 27. Studnia (fot. P. Świątkiewicz).

przysiółek Ziemiary (zu Ziemiary). Nie ma go także na wycinku 40-30 mapy w skali 1:100 000 Wojskowego Instytutu Geograficznego wydanej w 1936 roku, lecz opracowanej według danych zebranych w 1934 roku (ryc. 29). Zatem, odkryte $\mathrm{w}$ trakcie badań gospodarstwo nie mogło powstać wcześniej niż na początku lat dziewięćdziesiątych XIX wieku, a jego funkcjonowanie oraz prawdopodobnie istnienie znajdujących się w jego obrębie obiektów skończyło się zapewne już na początku lat trzydziestych XX wieku. 


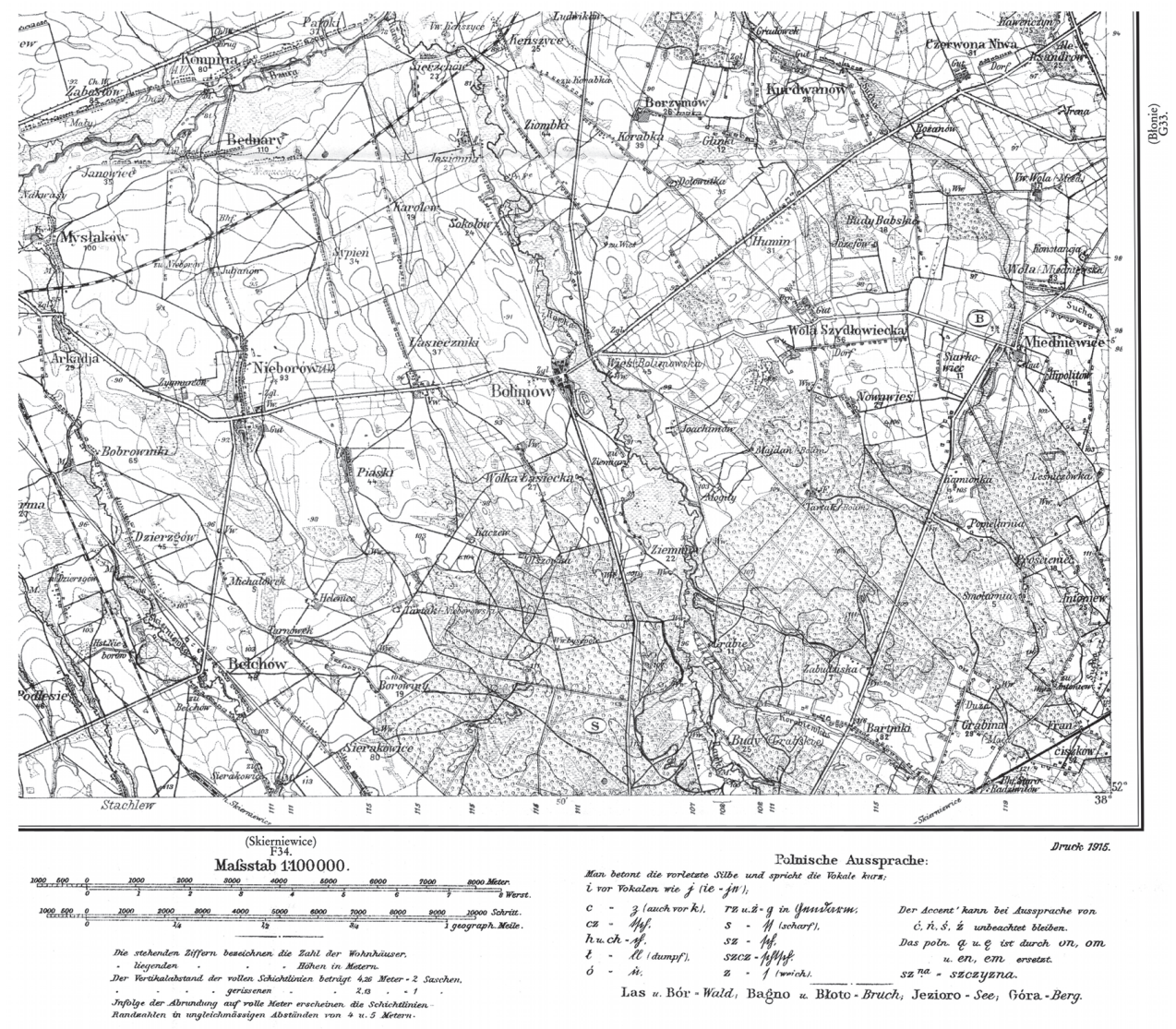

Ryc. 28. Wycinek mapy Karte des westlichen Russlands w skali 1:100 000 z 1915 r.

(Topmap).

\section{Reserve-Lager 21. Pułku von Borcke?}

W świetle powyższych informacji można uznać za więcej niż prawdopodobne, że pozostałości konstrukcji drewnianych (obiekty nr 48 i 87) oraz innych opisanych w tym rozdziale obiektów stanowią ślady inżynieryjnej działalności i pobytu $\mathrm{w}$ tym miejscu żołnierzy niemieckich, między innymi od połowy lutego do połowy maja 1915 r. 21. Pułku Piechoty z Torunia. Świadczą o tym co najmniej trzy poszlaki. Pierwszą z nich jest informacja o funkcjonującym nie w Bolimowie, lecz pod Bolimowem (bei Bolimów) Reserve-Lager, w którym odpoczywali i nabierali sił oraz szkolili się żołnierze $\mathrm{z}$ tej jednostki nieznajdujący się na pozycjach bojowych po wschodniej stronie Rawki. Usytuowanie obozu przybliżają dwie fotografie z cytowanej publikacji. Na pierwszej z nich, już przytaczanej, widać kąpiących się w rzece 


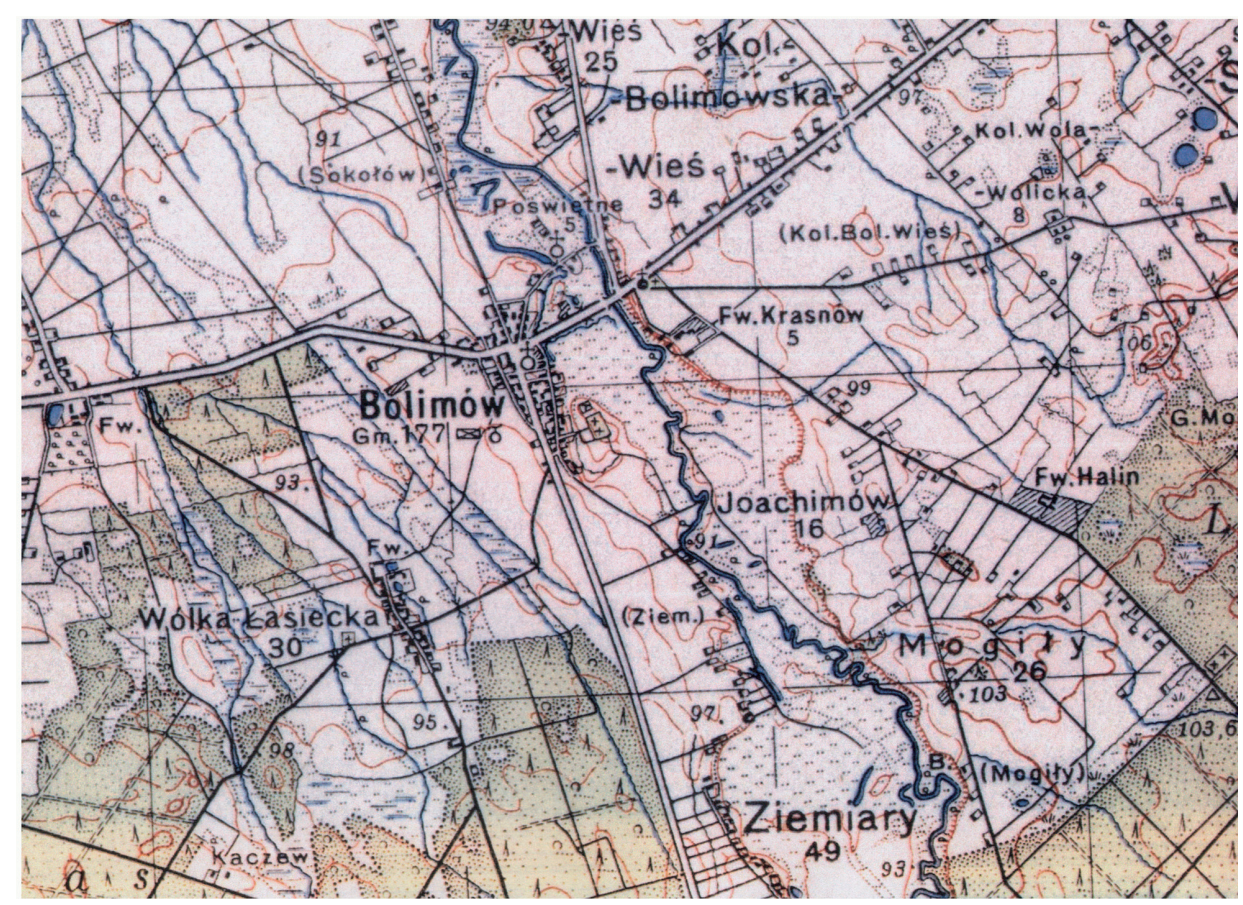

Ryc. 29. Wycinek (pas 40, słup 30, Łowicz) mapy WIG-u z 1936 r. w skali 1:100 000 (Topmap).

żołnierzy, a w dalekim tle tej sceny najprawdopodobniej zarysy mostu na Rawce $^{19}$. Zdjęcie drugie przedstawia kościół św. Anny w Bolimowie (Kriegsgeschichte..., Tafel 7/I). Sfotografowano go wraz z częściowo zrujnowanymi domami od strony dzisiejszej ulicy Senatorskiej, u wylotu której odkryto opisany tu zespół obiektów (ryc. 30). Trzecią poszlakę uprawdopodobniającą postawioną wyżej tezę stanowi szklana butelka z napisem: THORN znajdująca się $\mathrm{w}$ gospodarskim śmietniku sąsiadującym z domostwem odkrytym w trakcie badań.

Jak ustaliliśmy wyżej, chatę zbudowano najwcześniej w końcu XIX w., lecz z pewnością przed dotarciem nad Rawkę wojsk niemieckich. Trudno bowiem przyjąć, że podczas toczonych tu walk kwatermistrzostwo zajmowało się stawianiem budynków z piecami. Natomiast hipotezie o powstaniu tej zagrody dopiero po ustaniu działań wojennych przeczy fragment kokardy z rosyjskiej czapki i karabinowa łódka z poziomu użytkowego chaty. Zakłada-

${ }^{19}$ Uważny Czytelnik z pewnością dostrzeże, iż żołnierze kąpią się przy wschodnim, a nie zachodnim brzegu Rawki, na którym miałby być położony obóz. Jednakże tam właśnie był usytuowany nieznany autor zdjęcia. 


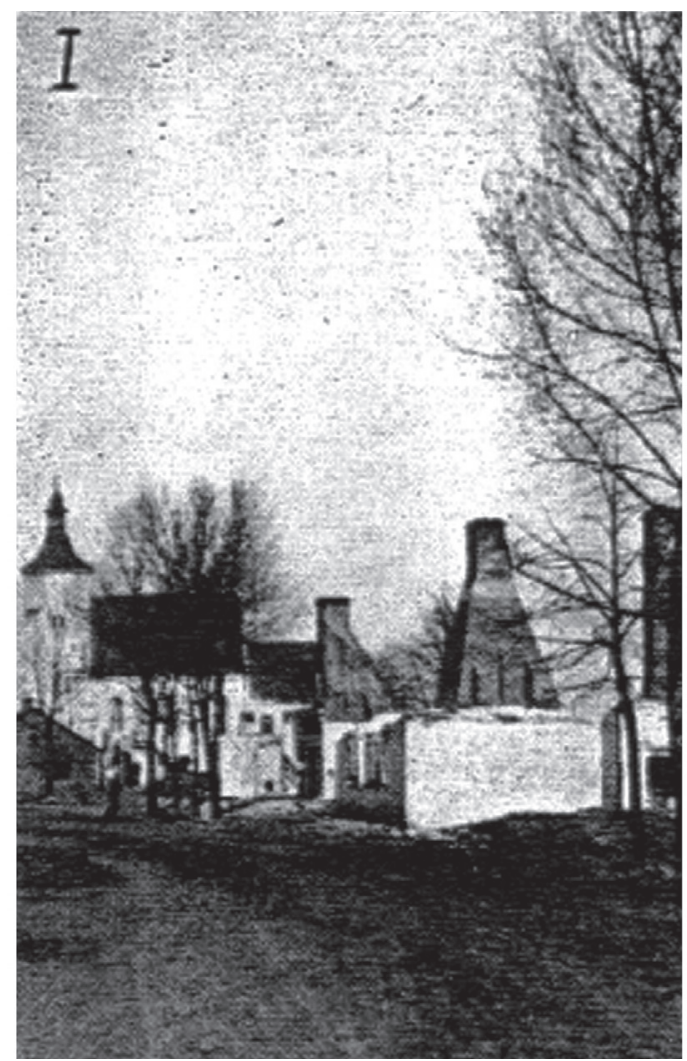

Ryc. 30. Bolimów 1915 r. Widok na kościół św. Anny od południa (Kriegsgeschichte..., Tafel 7/I).

my również, że nie została ona zniszczona w latach wojny, gdyż była użytkowana najprawdopodobniej do końca lat dwudziestych XX wieku. Pododdziały armii niemieckiej zajęły ją zapewne po opuszczeniu przez dotychczasowych mieszkańców lub po ich usunięciu. Była to powszechna praktyka stosowana na zapleczu frontu, co dokumentują opublikowane fotografie przedstawiające niemieckich żołnierzy przed podobnymi kwaterami (Kaliński 2010: 68) ${ }^{20}$. Pośrednio potwierdzają tę hipotezę także określenia miejsc zakwaterowania zawarte w cytowanej literaturze; w Bolimowie były to chaty/chałupy (Hütten), a na wschodnim brzegu Rawki Erdhütten, czyli całkowicie polowe, wziemne konstrukcje. Sądzimy zatem, że bolimowski Hüttenlager obejmował zarówno wiejską lepiankę zamieszkałą przez żołnierzy, jak i zbudowany później zie-

\footnotetext{
${ }^{20}$ Fot. u góry: „27 stycznia 1915 roku, żołnierze 18 Pułku Piechoty, 41. Dywizji świętują Urodziny Cesarza Wilhelma II na kwaterze". Zdjęcie z kolekcji Piotra Moskwy.
} 


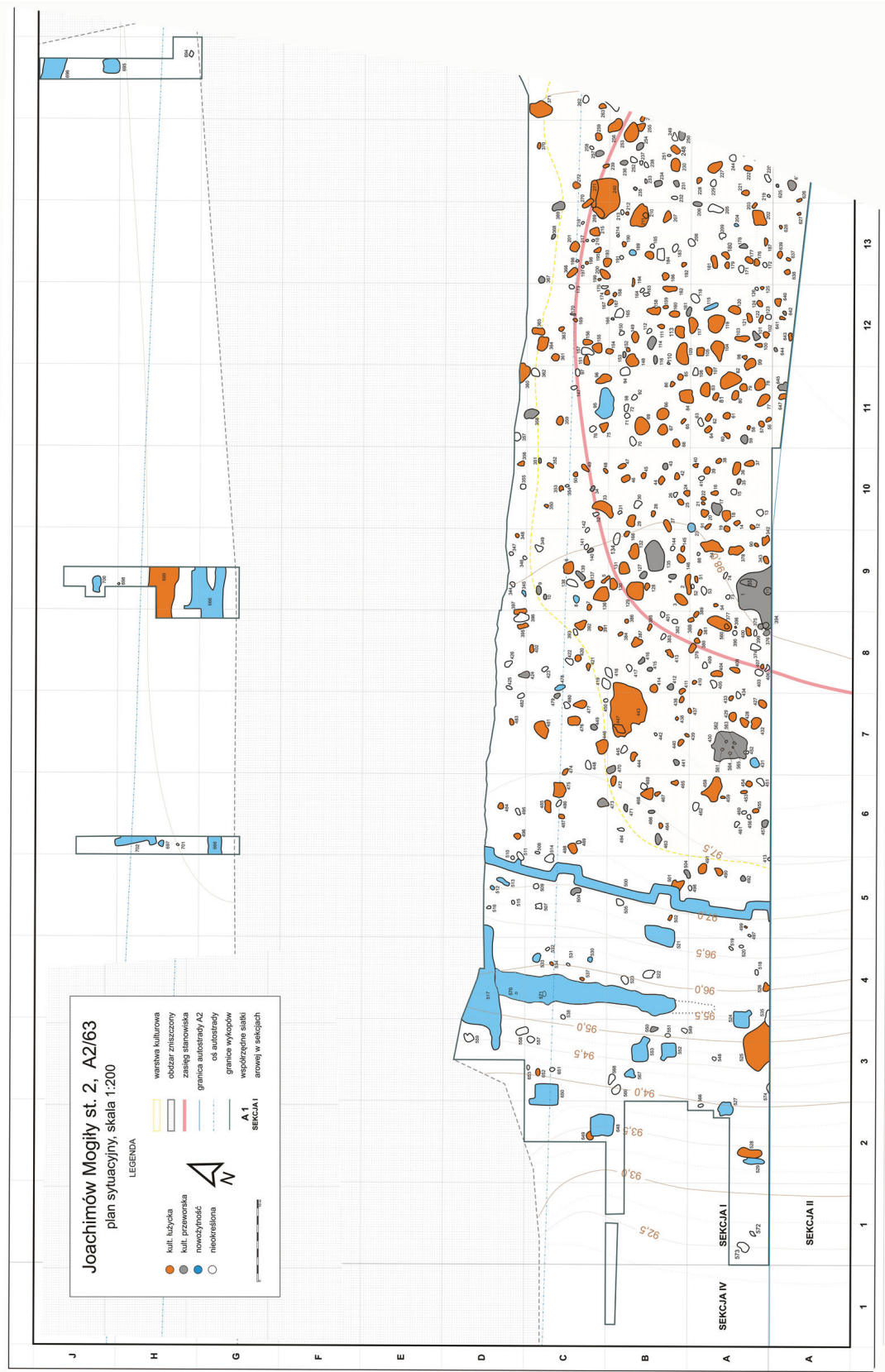


miankowy schron. Założyć też można, że na cały obóz składało się znacznie więcej segmentów, do których (lub z których) prawdopodobnie prowadziła transzeja dochodząca do schronu.

\section{JoACHIMÓW-MogILY 2008 ROK}

Powierzchnię stanowiska wstępnie oszacowano na około 250 arów, z czego do badań preliminowano 70 arów (ryc. 31). Prowadzono ratownicze badania wykopaliskowe. Stanowisko położone jest na skraju Puszczy Bolimowskiej, na cyplu wcinającym się w prawobrzeżną część doliny Rawki. Od strony wschodniej naturalną granicą stanowiska jest niewielki ciek wodny. Część północna została zniszczona przez budowę nasypu pod autostradę, tzw. „olimpijkę" w latach 70. XX w. W trakcie badań wykopaliskowych na stanowisku Joachimów-Mogiły 2 odkryto i wyeksplorowano 46 obiektów określonych jako nowożytne. Prace analityczne pozwoliły w niektórych przypadkach sprecyzować zarówno ich funkcję jak i chronologię (Natkański 2010; Olejnik $\mathrm{i}$ in. 2010).

$\mathrm{Na}$ będące przedmiotem poniższego opracowania „okopy” (fortyfikacje) składa się zespół odsłoniętych w zachodniej i północnej części wykopu obiektów o charakterystycznym kształcie pozwalającym na jednoznaczną ich interpretację. Należą do nich: pozostałości dwóch rowów (obiekty nr 500, 666), w przybliżeniu prostokątnych śladów ośmiu wkopów (obiekty nr 521, 524, 527, $552,553,648,650,695)$ oraz trzech wkopów odsłoniętych w położonych na północ odkrywkach (obiekty nr 696, 700, 702).

\section{Obiekt nr 500 (rów - okop)}

Obiekt określony jako ślady rowu zlokalizowany był na skraju łagodnego przeciwstoku doliny rzeki Rawki około $70 \mathrm{~m}$ na zachód od kulminacji wzniesienia w centrum stanowiska i około $1 \mathrm{~m}$ od niego poniżej na osi północ - południe. Szerokość rowu wynosiła od 100 do $160 \mathrm{~cm}$, co około $750 \mathrm{~cm}$ posiadał on czworokątne tzw. „poprzecznice wysunięte” o szerokości $340 \mathrm{~cm}$ i skierowane na wschód na około $200 \mathrm{~cm}$ od linii „okopu” (ryc. 32). W takcie badań odsłonięto pełny zarys dwóch poprzecznic i częściowo dwóch pozostałych. $\mathrm{Na}$ jednym z odcinków widoczne było poszerzenie o szerokości $160 \mathrm{~cm}$ i długości $200 \mathrm{~cm}$ stanowiące prawdopodobnie miejsce na skład amunicji lub pozycję ogniową(?). Przekrój pionowy rowu zbliżony był do trapezu o głębokości od 55 do $61 \mathrm{~cm}$, wypełnisko stanowiła warstwa żółtego i szarego piasku w układzie przemieszanym. Obserwacja profili wskazuje na jego jednorazowe zasypanie, a nie stopniowe powolne, naturalne zamulanie. Pierwotna głębokość okopu wraz z usuniętą warstwą humusową oraz nasypem uformowanym $\mathrm{z}$ wydoby- 


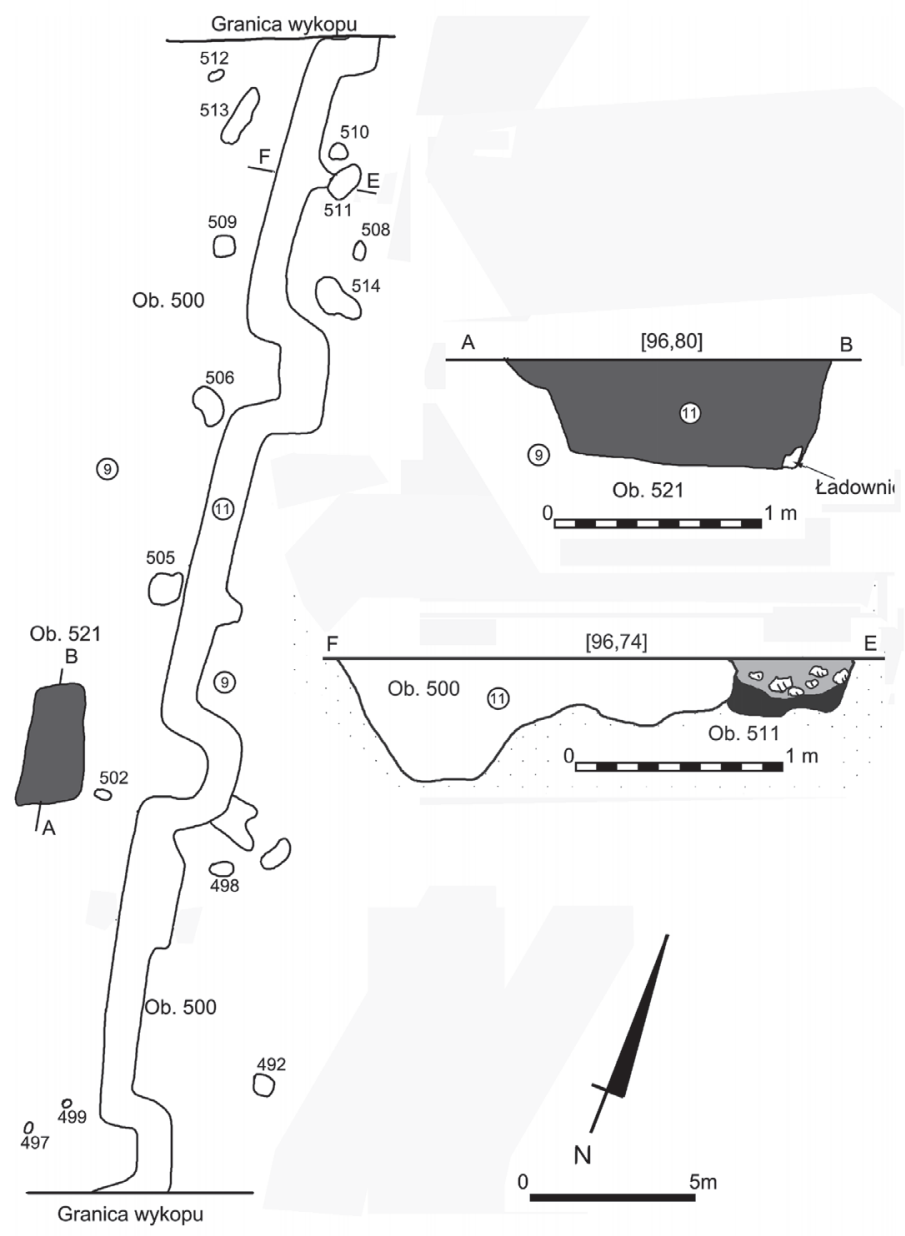

Ryc. 32. Obiekty nr 500 „okop”, 511 i 521 (plany i profile) na stan. 2 w Joachimowie-Mogiłach (za: Olejnik i in. 2010).

tej z niego ziemi mogła wynosić około $130-150 \mathrm{~cm}$. Wymiary „poprzecznic” i zarys przekrojów rowu zbliżone są do obowiązujących w polskich, rosyjskich i niemieckich instrukcjach saperskich z lat dwudziestych, które były wzorowane na instrukcjach wojskowych z okresu I wojny (tabl. II: b, c, e). W północnej części obiektu, po obu stronach „poprzecznicy” zachowały się ślady 2 półek na granaty i amunicję(?) o półkolistym zarysie i wymiarach około 60 x $60 \mathrm{~cm}$, głębokości od 22 do $30 \mathrm{~cm}$. Były to być może pozostałości tzw. „ławki strzeleckiej” (Podręcznik...: 385-425). 
Wśród przedmiotów metalowych znalezionych w wypełnisku okopu odkryto 22 ładowniki w 4 skupiskach, które dostały się do wnętrza podczas niwelowania powstałego przy krawędzi rowu nasypu. Mogą one sugerować nieliczne, możliwe do odtworzenia pozycje strzeleckie(?).

Również do śladów pozycji strzeleckich można zaliczyć między innymi pozostawione na dnie wykopu 3 paczki amunicji strzeleckiej (tabl. IV: a), 5 sztuk amunicji z ładownikiem oraz 1 łuskę. $\mathrm{W}$ wypełnisku obiektu zlokalizowano także 167 odłamków pocisków artyleryjskich, w tym dwa całe czerepy (tabl. IV: b), 2 fragmenty bliżej nieokreślonych przedmiotów metalowych oraz jedynie 2 przedmioty stanowiące osobiste wyposażenie żołnierzy: aluminiową łyżkę i uszkodzony scyzoryk o jednym ostrzu, ze śladami niezachowanej oprawy drewnianej. Ponadto w zasypisku obiektu natrafiono na 77 pocisków w większości amunicji typu Mosin. Ciekawym znaleziskiem okazał się parciano-skórzany bandolier zawierający komplet amunicji. Pozostawiony na dnie rowu zakonserwował pod sobą źdźbła trawy wyściełającej w tym miejscu dno okopu (Olejnik i in. 2010).

\section{Obiekty nr 521, 524, 527, 552, 553, 648, 650 i 695 (prostokątne wkopy)}

Obiekty te można podzielić na dwie grupy: ,a" - prostokątne wkopy z dwoma „progami” umieszczonym ukośnie $\mathrm{w}$ dwóch naprzeciwległych narożnikach (nr 524, 552, 553, 695); ,b” - prostokątne wkopy z jednym prostym „,progiem” w narożniku (nr 648, 650). Położone są one od około 10-15 m (,a”) i 15-20 m (,b”) za ,rowem”.

W obu grupach, podobnie jak w przypadku rowu, nie zachowały się ślady drewnianych szalunków lub innych konstrukcji wzmacniających. Interpretacja tych wkopów może być jedynie bardzo hipotetyczna. Grupa „b” ma wymiary i głębokość uprawdopodobniającą podejrzenie, że mogłyby być rodzajem niewielkich ziemianek (ang. dugout; tabl. II: a) o przeznaczeniu raczej magazynowym niż mieszkalnym (chociaż i tego nie można wykluczyć, ale tylko dla dwóch, trzech żołnierzy - schroniska dla dyżurujących?). Ich odległość od linii okopu - rowu (obiekt nr 500) jest zgodna z założeniami regulaminów armii niemieckiej (Ausbildungsvorschrift...). Grupa wkopów „,a” może mieć inne przeznaczenie. Ich kształt i rozmiary (głębokość) zgodne są z regulaminowymi założeniami budowy stanowisk ogniowych ckm.

W opisanych wyżej obiektach znaleziono łącznie 46 zabytków, do których zaliczyć należy m.in.: 17 sztuk naboi, łusek i amunicji strzeleckiej, 1 odłamek pocisku artyleryjskiego, fragmenty puszki po konserwie, aluminiowy guzik odzieżowy, skórzany pasek z klamerką (fragm. ładownicy?), 2 ułamki ceramiki nowożytnej, 21 fragmentów znacznie skorodowanych, bliżej nieokreślonych przedmiotów metalowych oraz 2 grudki polepy. 


\section{Obiekty nr 517 i 702}

Interpretacja pozostałych obiektów odsłoniętych na stanowisku w Joachimowie-Mogiłach przysparza nieco więcej trudności za sprawą m.in. ich szczątkowego zachowania. Należy do nich obiekt nr 517 o częściowo czytelnych wymiarach 1524 x $458 \mathrm{~cm}$ posiadający amorficzny zarys i głębokość do $20 \mathrm{~cm}$. Jego wymiary mogą sugerować istnienie w tym miejscu stanowiska dla okopanej armaty pułkowej. Obiekt zawierał 11 ułamków ceramiki nowożytnej, 1 fragment paska skórzanego, 5 naboi ostrołukowych, 1 łuskę typu Mosin, 1 łódkę (Mauser) oraz 7 różnych odłamków pocisków artyleryjskich.

Kolejny obiekt nr 702 zlokalizowano w wykopie sondażowym, w północnej części stanowiska, na skraju stoku doliny rzeki. Rozpoznany jedynie częściowo, posiadał w części objętej wykopem regularny zarys o wymiarach 494 x $152 \mathrm{~cm}$ i głębokości dochodzącej do $138 \mathrm{~cm}$. Wypełniały go przemieszane warstwy brunatnego oraz zaglinionego piasku z niewielkimi fragmentami zbutwiałego drewna. W jego dwóch odkrytych narożnikach znajdowały się czworokątne progi. $\mathrm{W}$ wypełnisku natrafiono na 6 fragmentów butelki o wklęsłym dnie z ciemnozielonego szkła, 2 fragmenty kamiennej osełki o przekroju prostokątnym, aluminiową buteleczkę oraz 15 fragmentów silnie skorodowanych przedmiotów, do których należy zaliczyć bagnet, 3 zawiasy drzwiowe, 2 fragmenty puszki konserwowej oraz 9 kutych gwoździ. Obiekt nr 702 stanowił najprawdopodobniej ziemiankę, częściowo zagłębioną w gliniasty calec.

\section{Obiekt nr 666 - rów i ziemianka(?)}

Obiekt był zlokalizowany w 2 wykopach sondażowych w północnej części stanowiska przy krawędzi stoku doliny rzeki Rawki. Czytelny na powierzchni stanowiska, został rozpoznany częściowo dwoma wykopami sondażowymi. Zachowany był w większości jedynie w formie negatywu, gdyż od strony zachodniej i południowej został zniwelowany podczas budowy nasypu pod „olimpijkę". W wykopie zachodnim, który objął swą powierzchnią okop na długości $200 \mathrm{~cm}$, obiekt zachował się w partii spągowej. Posiadał on regularny, wydłużony na osi wschód - zachód zarys w postaci płytkiego rowu o szerokości $200 \mathrm{~cm}$ z nieckowatą linią spągu. W wykopie wschodnim o szerokości 600 $\mathrm{cm}$ rów rozdzielał się na dwie części, każda o szerokości około $150 \mathrm{~cm}$. Od północnej strony negatywu rowu przylegały pozostałości czworokątnego założenia zachowanego w spągowych partiach. Tkwiły w nim resztki zbutwiałej deski, natomiast od strony wschodniej znaleziono 7 elementów fajerki mogącej być jedynym śladem po piecu. Podczas oczyszczania spągu rowu znaleziono m.in.: 1 monetę (10 fenigów; tabl. IV: e), 1 fragment puszki konserwowej, 1 zawias drzwiowy, 1 kuty gwóźdź, guzik odzieżowy, 2 fragmenty odłamków artyleryjskich oraz niewielką figurkę ołowianą świni, podobną do współcześnie dostępnych plastikowych zabawek dziecięcych (tabl. IV: d). 
Odkryte relikty należałoby interpretować jako kolejny element rowów - okopów z przylegającą przynajmniej jedną ziemianką od strony północnej, ogrzewaną piecem, po którym zostały elementy fajerki. Okopy tego typu pasują do linii fortyfikacji polowych stosownych w okresie I wojny światowej przez armię niemiecką w okolicach Bolimowa. Niejasne pozostają jednak wzajemne relacje pomiędzy obiektami o nr 500 i 666 . Teren został mocno zniszczony pracami ziemnymi w latach 70-tych. Usytuowanie względem siebie okopów może sugerować, że były połączone w jeden ciąg komunikacyjny.

\section{Znaleziska amunicji, broni i fragmentów oporządzenia wojskowego}

W ramach zespołu „oporządzenia wojskowego” (broń, amunicja etc.) w Joachimowie-Mogiłach znalezione zostały liczne elementy uzbrojenia i wyposażenia żołnierskiego. Omawiamy je kolejno, poniżej.

Bandolier - rodzaj pasa amunicyjnego noszonego przez pierś zawierającego kieszenie na naboje w łódkach lub ładownikach (magazynkach) używany w wielu armiach od XVII w. po dzień dzisiejszy, w armiach niemieckiej i rosyjskiej również. Znaleziony na stanowisku Joachimów-Mogiły bandolier, najprawdopodobniej rosyjski, wykonany był z parcianego płótna wzmocnionego skórzaną lamówką. Przyszyty do niego był skórzany pasek mocujący. Posiadał 4 kieszenie, które zawierały po 5 sztuk amunicji do karabinu typu Mosin (tabl. III: a, c).

Bagnet - słabo zachowany, złamany bagnet tulejowy nakładany (nieskładany!) wz. 1891 znaleziony w wypełnisku obiektu - ziemianki nr 702. Bagnetu wz. 1891 (potocznie: wz. 91) używano do karabinów i karabinków Mosin wz. 1891/98/23. Broń tego typu produkowano w kilku rosyjskich fabrykach oraz w kilku poza granicami Rosji. Poszczególne sztuki różnią się od siebie jakością wykonania i drobnymi szczegółami. Głownia omawianego zabytku jest stalowa, o przekroju „krzyżowym” (czterograniastym), oksydowana, sztych centralny, typu śrubokręt. Bagnet wz. 91 należał do egzemplarzy tulejowych, blokowanych tzw. pierścieniem środkowym. Jego podstawowe dane to pierwotna długość całkowita: $502 \mathrm{~mm}$; długość zachowanej głowni: 430,5 mm; średnica głowni: $16,5 \mathrm{~mm}$; długość tulei: $71,5 \mathrm{~mm}$; wewnętrzna średnica tulei: $15-15,5 \mathrm{~mm}$ (tabl. IV: c).

Amunicja artyleryjska - prawdopodobnie rozmontowane „czerepy” (tabl. IV: b) pocisków artyleryjskich dla armaty pułkowej FK wz. 96 n.A., kalibru $7,7 \mathrm{~cm}$. Był to zapewne szrapnel, co uprawdopodabnia mała grubość pancerza „czerepu”. Masa pocisku wynosiła 6,85 kg (Konstankiewicz 2003). W tę kategorię armat uzbrojona była między innymi 35. Dywizja Artylerii Polowej, 1. Zachodniopruska (1. Westpreußische Feldartillerie-Division, $\mathrm{Nr} 35$ ), a w jej ramach elementy 81. Toruńskiego Pułku Artylerii Polowej (Thorner Feldartillerie-Regiment, Nr 81) działającego pod Bolimowem jako wsparcie 
XVII Korpusu Piechoty. W pociskach brak głowic zapalnika i elementów detonujących. „Czerepy” zostały znalezione w północnej części okopu (obiekt nr 500).

Amunicja strzelecka - oprócz kilku sztuk amunicji luzem zalegających w wypełniskach okopu i innych obiektów w Joachimowie-Mogiłach odkryto między innymi trzy, owinięte fabrycznie papierem, paczki amunicji ostrołukowej o trapezowatych łuskach i tępołukowej w „łódkach ze ściankami” (tabl. IV: a). Zarejestrowano także jeden pełny „ładownik asymetryczny” do karabinu Mauser-Manlicher kal. 7,92[R].

Różnorodność znajdowanej w obiektach amunicji, pozostaje w zgodzie z ustalonymi wcześniej etapami reorganizacji (przezbrajania) obu armii. Zarówno w armii niemieckiej jak i rosyjskiej niektóre formacje broni i jednostki (kawaleria, artyleria, kozacy, pierwszoliniowa piechota, pułki rezerwowe czy oddziały tyłowe - wartownicze) mogły posługiwać się różnym uzbrojeniem. Zwłaszcza w latach 1914-1915 na tym traktowanym drugoplanowo, przynajmniej przez Niemców froncie. W późniejszym okresie, dzięki pracującym na „pełnych obrotach" zakładom zbrojeniowym i na skutek naturalnego zużywania się zapasów starszych odmian broni i amunicji różnice te stopniowo zaczęły zanikać.

Łódki i ładowniki amunicyjne (rosyjskie i niemieckie) - w obiektach badanych w Joachimowie-Mogiłach znaleziono kilka zwykłych łódek do niemieckiej amunicji Mauser 7,92 wz. 98 (ryc. 38), co najmniej jeden ładownik asymetryczny Mauser-Manlicher (wz. 88) i kilka sztuk łódek ze ściankami (tabl. III: b, d; V: f: 3) - prawdopodobnie rosyjskich, zachowanych w tak złym stanie, że precyzyjne określenie kalibru, a co za tym idzie próba ustalenia ich pochodzenia okazała się ostatecznie niemożliwa.

Moneta - 10 fenigów niemieckich z roku 189[0 lub 9?] odkryta w obiekcie nr 666 (tabl. IV: e).

Strzemię - zabytkiem pochodzącym prawdopodobnie z okresu I wojny światowej jest zlokalizowane w stropowej części obiektu nr 696 strzemię jeździeckie o łukowato wygiętym pałąku i ażurowej stopce (tabl. IV: f), mogące pochodzić z oporządzenia niemieckiego.

Guziki - większość znajdowanych na różnych stanowiskach z I wojny światowej guzików to typowe elementy stroju (munduru) wojskowego, zarówno wierzchniego (kurtek czy płaszczy) jak i bielizny (koszul czy „gaci”). W przypadku Joachimowa-Mogił znaleziono tylko dwa takie egzemplarze. Jeden z nich to typowy guzik bieliźniany (wykonany z tworzywa sztucznego; 3 dziurki w układzie trójkąta) o nieokreślonym pochodzeniu (niemiecki?). Drugi, to metalowy ,guzik” o trzech dziurkach (w jednej linii) i mocno wywiniętej krawędzi (tabl. V: a), przypomina on trochę blaszaną podstawę pod „bączek” do czapki pruskiego szeregowca - Fusilier Feldmütze, sprzed 1905/1906 roku (tabl. V: b), bez daszka. Jest to bączek typu starego, o czasami tkaninowym 
barwnym wypełnieniu i metalowej spince w formie drucianej zszywki. Guzik ten został znaleziony w wypełnisku I warstwy mechanicznej obiektu nr 500 (I/A2 c-d) określonego jako „okop”.

\section{Próba interpretacji funkcji umocnień ziemnych w Joachimowie-Mogiłach}

Okop zlokalizowany jest frontem do rzeki Rawki, a na jej przeciwległym brzegu, naprzeciw okopu, znajdowały się również niemieckie stanowiska tyłowe, tworzące najprawdopodobniej opisany w poprzedniej części artykułu Reserve-Lager, między innymi 21. Pułku Piechoty von Borcke. Wszystkie jego cechy, położenie „ławki strzeleckiej”, ,poprzecznic” i skrycie jego biegu, na stoku poniżej szczytu niskiego wzniesienia, wskazują na jego specyficzną funkcję. Prawdopodobnie był on okopem flankującym (ubezpieczającym), niejako uszczelniającym brzeg szeroko rozlanej, meandrującej rzeki w rejonie przecięcia jej przez linię frontu oraz chroniącym położone po przeciwnej stronie koryta Rawki zaplecze frontu, czyli wspomniany Reserve-Lager. Obecność w okopach i ziemiankach amunicji rosyjskiej, bagnetu i rosyjskiego bandoliera może być związana ze wspomnianym wcześniej dniem 24 lutego 1915 r., kiedy to Rosjanie włamali się na krótko w niemieckie linie obronne (zob. część Bolimów, grudzień 1914 roku - maj 1915 roku) być może właśnie atakiem wzdłuż biegu rzeki. Prawdopodobnie przez jakiś czas przebywali w zdobytych okopach, a potem zostali z nich wyparci, tracąc ludzi i nieco drobnego sprzętu. Miejscowa ludność wspomina o dwóch pochówkach „...ruskich - gdzieś w pobliżu...”. Kilka miesięcy później, odchodząc z okopów, żołnierze niemieccy zabrali ze sobą swoją amunicję, gubiąc kilkadziesiąt sztuk. Rosyjską amunicję, bandolier i uszkodzony bagnet Niemcy zostawili, gdyż nie były im do niczego potrzebne. Od strony wschodniej i północno-wschodniej tych umocnień, a więc zgodnej ze spodziewanym przecież kierunkiem ataku, zlokalizowane były dodatkowe obiekty mieszkalno-magazynowe w postaci licznych ziemianek (sic!?). W związku z tym, podkreślamy - „okopy” nie stanowią fragmentu żadnej z licznych linii umocnień frontu. Ani pierwszej ani nie ostatniej ${ }^{21}$.

Istnieje też inna możliwość wyjaśnienia dość dziwnej lokalizacji opisywanego okopu. Otóż około $250 \mathrm{~m}$ na zachód od przedpiersia okopu (stan. nr 2) na rzece Rawce znajdował się wspominany już „bród”22 zaznaczony na mapach międzywojennych WiG-u i współczesnych mapach w skali 1:10 000. Być może znane niemieckiemu dowództwu miejsce ułatwionego przejścia przez rzekę skłoniło je do zabezpieczenia go, nie tylko schronem w Reserve-Lager

${ }^{21}$ Pierwsza przebiegała zapewne dalej na wschód, bliżej wsi Mogiły, a inna, być może ostatnia, pół lub półtora kilometra na zachód, przecinała wymieniony we wspomnieniach żołnierskich „punkt topograficzny 99” (Kriegsgschichte...: 167).

${ }^{22}$ Obecnie dokładnie w miejscu brodu przebiega nitka autostrady i możliwość skontrolowania jego dokładnego przebiegu została ostatecznie utracona na skutek mostowych prac inżynieryjnych. 
na wschodnim brzegu Rawki, lecz także od strony zachodniej dodatkową linią okopów, licząc się z potrzebą korzystania z brodu w razie zerwania przeprawy mostowej w Bolimowie na skutek działań nieprzyjaciela.

Na marginesie naszych rozważań zwraca uwagę zauważalna różnica w traktowaniu budowy umocnień i okopów przez obie wrogie armie. Staranne dopracowane technicznie, ze z góry przygotowanymi projektami prac okopy niemieckie i niemalże przypadkowe, bałaganiarsko prowizoryczne okopy rosyjskie. Przyczyny tego leżą: po pierwsze w założeniach taktycznych obu armii i po drugie w środowisku, w jakim zwykły były szkolić się i walczyć. Armia niemiecka w założeniach taktycznych opierała się na wielkich jednostkach piechoty wspartej artylerią i mniej licznymi oddziałami kawalerii, co sprzyjało budowaniu stałych umocnień w miejscach ,chwilowego - sezonowego" zatrzymania się frontu. Rosyjska taktyka mimo istnienia wielkich jednostek piechoty, zakładała prowadzenie raczej wojny manewrowej opartej o wielkie mobilne jednostki kawalerii, co nie sprzyjało starannemu planowaniu umocnień polowych. Z drugiej strony klimat obu krajów nieco się różnił. Ważne szkoły oficerskie armii rosyjskiej zakładane były w Moskwie, Petersburgu, Kazaniu i Twerze, a więc w miastach gdzie surowa zima trwa nieco dłużej. Mocno zamarzająca ziemia nie łatwo poddaje się łopacie - nie sprzyja to szukaniu rozwiązań taktycznych w oparciu o rozbudowane ziemne umocnienia.

\section{UWAGI KOŃCOWE}

Rozpoczynając pracę nad powyższym artykułem założyliśmy sobie realizację dwu podstawowych celów. Pierwszym z nich było przedstawienie wyników badań bojowych umocnień ziemnych z czasów I wojny światowej w Bolimowie i Joachimowie-Mogiłach. Cel ten został, jak się wydaje, pomyślnie zrealizowany we wcześniejszych partiach tekstu. Stanowi on ponadto punkt wyjścia do spostrzeżeń i refleksji dotyczących specyfiki badań archeologicznych na podobnych stanowiskach. Spróbujemy niektóre z nich wyartykułować.

Opisywane zmagania pomiędzy wrogimi armiami rozgrywały się na obszarze o powierzchni około $33 \mathrm{~km}^{2}$, ograniczonym od wschodu korytem Rawki, a od południa i zachodu linią frontu biegnącą od Ziemiar, przez Joachimów, Wolę Szydłowiecką, Humin i Kurabkę do Suchej. Studiując ich wiarygodne opisy odnosimy nieodparte wrażenie, iż składały się one przede wszystkim z nieustannego, mozolnego drążenia naturalnej powierzchni, utrudnionego surowymi warunkami przyrodniczymi i przerywanego jedynie od czasu do czasu krwawymi starciami. W wyniku budowy, przebudowy i rozbudowy olbrzymiej liczby różnego typu rowów i gniazd, powstało gigantyczne kretowisko o skomplikowanym układzie elementów powstałych w różnych fazach wydarzeń i do rozmaitych celów. Badania archeologiczne z 2005 i 2008 roku odsłoniły 
jedynie niewielką część zaplecza oddziałów niemieckich, czyli tego, co według nas stanowi tzw. Reserve-Lager w Bolimowie oraz chroniące go, linie obrony zorganizowane, jak się wydaje, podczas szturmów Rosjan, na między innymi Jägernase. Ze wszystkimi tymi miejscami związana była mniej lub bardziej bezpośrednio działalność 21. Pułku piechoty von Borcke.

Powstaje w tym miejscu pytanie o sens i realną możliwość zbadania pozostałej przestrzeni bolimowskiego pola bitwy. Dotyczy ono zresztą innych XX-wiecznych podobnych stanowisk. Ich przestrzenne rozmiary oraz występujące na nich zagrożenia z pozostałościami uzbrojenia i wyposażenia stanowiły i nadal stanowią dla badaczy obiektywne czynniki zniechęcające do metodycznego rozpoznania. Analogiczne wydarzenia rozgrywały się do końca XIX wieku na obszarach wielokrotnie mniejszych i względnie ograniczonych, które można rozpoznać posługując się tradycyjnymi metodami archeologicznymi bez stosowania specjalnych procedur bezpieczeństwa. Natomiast wielkość pola bitwy pod Bolimowem i wielu jemu podobnych sprawia, że nie da go się całkowicie przebadać, nawet przy pomocy najbardziej szczegółowych prospekcji terenowych bądź szerokopłaszczyznowych odkrywek. Niejednokrotnie, tak jak np. w Bolimowie i Joachimowie-Mogiłach, o odkryciu nowych obiektów decyduje przypadek. Generalnie pragmatyka badawcza podpowiada, że w takich sytuacjach należy się skoncentrować na badaniu zlokalizowanych, węzłowych, najbardziej charakterystycznych punktów. Takimi miejscami w przypadku Joachimowa-Mogił stały się żołnierskie, polowe pochówki i teren zażartych walk o Jägernase ${ }^{23}$.

Wspomniano już we wstępie o pewnej nonszalancji z jaką do niedawna były traktowane przez archeologów pamiątki zbierane i odkrywane na terenach nowożytnych pól bitewnych nawet w czasie regularnych badań wykopaliskowych. Nie ustrzegli się jej też całkowicie piszący te słowa, co skutkowało niedookreśleniem chronologii obiektu $\mathrm{nr} 34 \mathrm{w}$ Bolimowie. Zjawisko to wynikało głównie, z dość subiektywnej oceny przemysłowych artefaktów jako materiału mniej wartościowego poznawczo od rzemieślniczych wyrobów pradziejowych lub średniowiecznych. Wiązała się z tym nutka pewnego akademickiego lekceważenia pierwszej wymienionej grupy zabytków. $Z$ dużą pedanterią zbierano z wykopu najmniejsze okruchy, np. ceramiki ręcznie lepionej i niekiedy potrafiono wyrzucić na hałdę różne nowożytne ,żelastwo”, w tym części uzbrojenia i umundurowania. Często nie wynikało to ze złej woli lub niedbalstwa badacza, lecz po prostu z braku wiedzy o tak specyficznych zabytkach, której przecież nie uzyskał w trakcie studiów. Czasami archeolodzy zajmujący się na co dzień

${ }^{23}$ Badania pola bitwy pod Bolimowem podjęte w 2012 r. są i będą kontynuowane mimo braku spektakularnych wyników i niesprzyjającej atmosfery panującej w lokalnym administracyjnym i społecznym otoczeniu (więcej Zalewska 2013: 41-43). 
osadnictwem różnych epok lub jego wpływem na środowisko człowieka pozwalali sobie na dość swobodne traktowanie śladów ostatnich stu lat. Wydawałoby się dobrze znanych i bogato udokumentowanych. Często prowadziło to do błędów i przeoczeń. Podobnie rzecz się ma w przypadku cmentarzy po-bitewnych czy post-ekshumacyjnych (Natkański 2004: 114-123). Zapominano przy tym, że w sensie poznawczym są to równorzędne przedmioty badań i źródła informacji, którym należy jednak stawiać odpowiednio dobrane pytania. Nie pamiętano także, że to, co dzisiaj jest dla nas jeszcze prawie żywą materią historyczną dobrze opisaną i udokumentowaną $\mathrm{w}$ inny sposób, już wkrótce stanie się odległą przeszłością porównywalną np. $\mathrm{z}$ bitwą pod Grunwaldem.

Jak wskazują nasze doświadczenia, interpretacja znalezisk i obiektów jest w przypadku pól bitewnych dość utrudniona. Nawet najdrobniejsze szczegóły i ich obserwacja mają tu wielkie znaczenie dla dalszego wnioskowania. Stąd nasz wniosek i apel do wszystkich archeologów o skrzętne podejmowanie z wykopu i rejestrowanie każdego zabytku, niezależnie od jego rzeczywistej lub podejrzewanej funkcji, chronologii lub stanu zachowania. Tu od razu uwaga: specyfika XX-wiecznych pól bitewnych polega także na obecności pozostałości uzbrojenia zaczepnego zagrażającego życiu i zdrowiu ludzi. Stąd wynika konieczność objęcia tego rodzaju stanowisk codzienną ochroną saperską wyposażoną w specjalistyczny sprzęt i umożliwiającą bezpieczną eksplorację warstw i obiektów. $Z$ braku takiej ochrony nie wyeksplorowano w Bolimowie do spągu obiektu nr 67, w którym poza orłem z hełmu odkryto „podejrzane” resztki nieopróżnionych opakowań chemikaliów ${ }^{24}$. Sugerujemy ponadto, aby każdy potencjalny badacz zdobył wcześniej wiedzę o żołnierskim uzbrojeniu i wyposażeniu oraz związanych z nimi zagrożeniach. Niezależnie od tego potrzebna byłaby ciągła współpraca archeologów ze znawcami historii, techniki i taktyki wojskowej, mundurów i falerystyki, antropologów i wreszcie last but not least, przedstawicieli PCK, służby sanitarno-epidemiologicznej i kapelanów.

Traktowanie tego rodzaju stanowisk z wszelkimi regułami stosowanymi w badaniach archeologicznych jest konieczne nie tylko dlatego, że są to miejsca równorzędne pod względem rzeczywistego i potencjalnego ładunku informacji z innymi źródłami materialnymi i pisanymi. Dodatkową przesłanką wzmacniającą tę tezę jest okoliczność zainteresowania nimi przez mniej lub bardziej amatorskich zbieraczy penetrujących teren w celu pozyskiwania dla siebie spektakularnych pamiątek wojennych, a przy okazji innych zabytków. Mnóstwo atramentu zużyto dotychczas opisując mniej lub bardziej szkodliwe skutki działalności osób zajmujących się „czarną archeologią” (Zalewska 2013:

${ }^{24}$ Po tej sytuacji pracom archeologów w Bolimowie towarzyszył na miejscu patrol saperski, dzięki któremu zlokalizowano i zneutralizowano przed eksploracją wykopu np. szereg pocisków artyleryjskich z II wojny światowej. 
43-45; Sabaciński 2015, tam dalsza literatura). Dodać do nich można mało chwalebny, a nawet przestępczy proceder uprawiany przez niektóre oddziały i współpracowników niemiecko-polskiej fundacji Pamięć zajmującej się ekshumacją i przenoszeniem do zbiorowych mogił zwłok żołnierzy niemieckich z I i II wojen światowych. Chociaż takie pojedyncze sprawy są wreszcie coraz energiczniej zwalczane przez służby konserwatorskie i organy ścigania, to należy zdawać sobie sprawę, że zjawiska tego nie można całkowicie opanować. Mając powyższe na uwadze, sądzimy, że im bardziej profesjonalnie będziemy traktować pola bitew jako przedmiot interdyscyplinarnych badań, tym bardziej przezornie i powściągliwie będą postępować obecni i przyszli amatorzy łatwych łupów. Tym chętniej będą też oni współpracowali z ludźmi zajmującymi się zawodowo tą samą problematyką i tym mniej będzie spraw, które nigdy nie ujrzą światła dziennego pozostając w zakurzonej szufladzie domorosłych odkrywców.

$* * *$

$\mathrm{Na}$ koniec wypada powrócić do drugiego założonego we wstępie celu tego artykułu, czyli konfrontacji materiałów archeologicznych ze źródłem pisanym. Naszym zdaniem, był to zabieg konieczny. Wzbogacił on ogólną wiedzę historyczną na temat bolimowskiej bitwy o materialne fakty dotyczące miejsca i warunków niektórych działań bojowych oraz pozafrontowego bytowania żołnierzy armii niemieckiej, którzy ponad dziewięćdziesiąt lat temu zmagali się z surową przyrodą i okrucieństwem wojny. Spróbowaliśmy także powiązać „,martwe” zabytki z konkretnym pododdziałem tej armii i z ludźmi o niejednokrotnie znanych nazwiskach.

Choć brak jest ostatecznych dowodów potwierdzających istnienie takiego związku, to w naszym przekonaniu, przemawiają za nim wyraźne poszlaki. Hipotezę tę mogą zweryfikować jedynie dalsze badania terenowe i archiwalne.

Karol E. Natkański

Łódź

e-mail: natkanred@gmail.com

Piotr Świątkiewicz

Łódź

e-mail: parkona@interia.pl 


\section{Bibliografia}

Ausbildungsvorschrift... (1906), Ausbildungsvorschrift fuer Fusstruppen im Kriege, Berlin (przedruk z 1918 r.).

Chylińska D. (2013), Pole bitwy jako przedmiot zainteresowania i przystosowania turystycznego-zarys problematyki, „Turystyka kulturowa”, nr 11, s. 6-16.

Chylińska D., Kosmala G. (2011), Krajobraz po bitwie. Niewykorzystany potencjat turystyczny pól bitew na przykładzie wojen śląskich, [w:] K. Widawski (red.), Turystyka kulturowa na Dolnym Śląsku - wybrane aspekty, t. 2, Uniwersytet Wrocławski Instytut Geografii i Rozwoju Regionalnego, Wrocław, s. 33-69.

Dubrowska M. (1997), Zakłady brąownicze krasnosielskiego, wasilewskiego, krantza (vel krańca) $i$ ich odlewy artystyczne, „Almanach Muzealny”, nr 1, s. 125-144.

Hanc-Maik E. (2010), Monety z Bolimowa stanowisko nr 9 gmina loco, powiat Skierniewice, województwo łódzkie znalezione $w$ trakcie badań archeologicznych na terenie autostrady A1, [w:] P. Świątkiewicz 2010, Wyniki badań archeologicznych w Bolimowie, st. 9 (6-62 na mapie zbiorczej), pow. Skierniewice w 2005/2007 r., cz. II, Aneksy, Łódź, maszynopis dostępny w archiwum IAiE PAN w Łodzi, bez numeracji stron.

Infanterie-Regiment..., Nr 21, https://www.google/gen.wiki.genealogy/net_IR21/Infanterie-Regiment von Borcke (4. Pommersches) (dostęp: 20.01.2017).

Kaliński S. (2010), Ataki gazowe w bitwie pozycyjnej 9. Armii Niemieckiej nad Rawka i Bzura 1914-1915, Fort, Przemyśl.

Kaliński S. (2015), Bolimów 1915, Bellona, Warszawa.

Konstankiewicz A. (2003), Broń strzelecka i sprzęt artyleryjski formacji polskich $i$ Wojska Polskiego 1914-1939, Wydawnictwo UMCS, Lublin.

Kriegsgeschichte... (1931), Kriegsgeschichte des Königl. Preuß. Infanterie-Regt. von Borcke Nr 21, Nach amtlichen Unterlagen und Berichten der Mitkämpfer, oprac. R.D. Hall, D. Fock, D. Dahle, Verein der Offiziere des ehem. Inf. Rgt. von Borcke, drukarnia Bernhard Sporn, Zeulenroda.

Królikiewicz T. (1997), Bagnety, Bellona, Warszawa.

Natkański K.E. (2004), Wstępne sprawozdanie z prac archeologiczno-antropologicznych w Maniewiczach $i$ Kołkach na Ukrainie, „Przeszłość i Pamięć. Biuletyn Rady Ochrony Pamięci Walk i Męczeństwa”, nr 3-4 (32-33), s. 114-123.

Natkański K.E. (2010), Okopy z I Wojny Światowej na stanowisku archeologicznym (nr st. 2, a2/63) w Joachimowie-Mogiłach. Analiza elementów fortyfikacji i fragmentów uzbrojenia, Łódź, maszynopis dostępny w archiwum PAK Kairos-Plus.

Olejnik K. (2006), Wojna jako przedmiot badań historycznych, Wydawnictwo Adam Marszałek, Toruń.

Olejnik J., Skowron J., Zagórska K. (2010), Opracowanie wyników archeologicznych badań ratowniczych $w$ Joachimowie Mogitach, stanowisko 2 (aut. 63), gm. Bolimów, woj. łódzkie, Łódź, maszynopis dostępny w archiwum PAK Kairos-Plus.

Podręcznik... (1930), Podręcznik podoficera, Warszawa.

Sabaciński M. (2015), Relikty archeologiczne Wielkiej Wojny. Znikajace dziedzictwo, poza nawiasem nauki i konserwatorstwa, „Ochrona Zabytków”, nr 1, s. 131-140. 
Schreiber G. (1889), Geschichte des Infanterie-Regiments von Borcke: (4. Pommerschen) Nr. 21, 1813 bis 1889, Ernst Siegfried Mittler und Sohn, Berlin.

Starzewska M., Jeżewska M. (1978), Polski fajans, Ossolineum, Wrocław-WarszawaKraków-Gdańsk.

Surer H., Bajonettsamlung, http://schuerer-pku.de/HS/bajonette DE.html. (dostęp: 28.01.2017).

Świątkiewicz P. (2010), Wyniki badań archeologicznych $w$ Bolimowie, st. 9 (6-62 na mapie zbiorczej), pow. Skierniewice w 2005/2007 r., cz. I, Tekst, cz. II, Aneksy, Łódź, maszynopis dostępny w archiwum IAiE PAN w Łodzi, bez numeracji stron.

Świątkiewicz P. (2011), Wyniki badań archeologicznych przeprowadzonych $w$ sezonach 2005-2007 w Bolimowie na stanowisku 9, pow. skierniewicki, woj. łódzkie, „Raport 2005-2006", s. 189-204.

Weltkrieg... (1929), Der Weltkrieg 1914 bis 1918. Die militärischen Operationen zu Lande, t. VI, Der Herbst-Feldzug 1914. Der Abschluß der Operationen im Westen, E.S. Mittler \& Sohn, Berlin.

Weltkrieg... (1931), Der Weltkrieg 1914 bis 1918. Die militärischen Operationen zu Lande, t. VII, Die Operationen des Jahres 1915. Die Ereignisse im Winter und Frühjahr, E.S. Mittler \& Sohn, Berlin.

Weltkrieg... (1932), Der Weltkrieg 1914 bis 1918. Die militärischen Operationen zu Lande, t. VIII, Die Operationen des Jahers 1915. Die Ereignisse im Westen im Frühjahr und Sommer, im Osten vom Frühjahr bis zum Jahreschluß, E.S. Mittler \& Sohn, Berlin.

Wolski K. (2008), Polskie pola bitew w świetle archeologii. Średniowiecze i okres nowożytny, Wydawnictwo i Agencja Informacyjna WAW, Racibórz.

Wrzosek J. (2010), Pola bitew - ważny element dziedzictwa, „Ochrona zabytków”, nr 1-4, s. 173-182.

Zalewska A. (2013), Archeologia stosow(a)na. Materialne pozostatości pierwszej wojny światowej: między pamięcia ,,fundacyjna” a ,, bibliograficzna”, między ,,czarna archeologia” " a ,archeologia konfliktu”, „Sprawozdania Archeologiczne”, t. 65, s. 31-49. 


\section{SumMary}

\section{INFANTRY REGIMENT VON BORCKE (4. POMERANIAN) IN BATTLE UNDER BOLIMOW IN THE LIGHT OF ARCHAEOLOGICAL INVESTIGATIONS}

The article narrated mainly the results of the archaeological research carried out in the little town Bolimów, Pl. 9 (St. 9) in 2005 and village Joachimów-Mogiły Pl. 1 (St. 1) in 2008, on the newly built route of the highway A no. 2, (near Skierniewice in Central Poland). The results of the surveys have been limited only to the threads relating to World War I.

At the same time, this article is an attempt to bind the information obtained during the test from the message history published in 1931 in the form of memories, providing a description of the combat route 21. Inf. Regiment called von Borcke at Thorn (Toruń).

This unit from mid-February to mid-May 1915, stayed near the city of Bolimów. The battalions fighting directly on the front lines, occupied the positions in the trenches in the vicinity of the village Humin, to the east of the river Rawka. Other subunits were lodged in the camp called "Reserve-Lager". This Reserve-Lager is located, according to the guidelines contained in the publication, on the southern edge of Bolimów, on the western riwer bank of Rawka.

In this place, in the course of archaeological research carried out on the route of the highway A no. 2, some traces of fortifications (trench and shelter) and remains of German soldiers from the war were discovered. Some paper monuments allow to bind them with Torun 21. Inf. Regiment. At the same time, on the opposite bank of the Rawka, in the village of Joachimów-Mogiły, some fragments of trenches as well as a hidden access to the ford on the Rawka and to Resereve-Lager were recorded.

The material presented in the article is a hypothetical thesis complemented by knowledge of modern battlefields. Also, it provides a basis for the formulation of several author's own comments for the discussion on the methodology of the emerging field of science that the archaeology of modern battlefields becomes. 

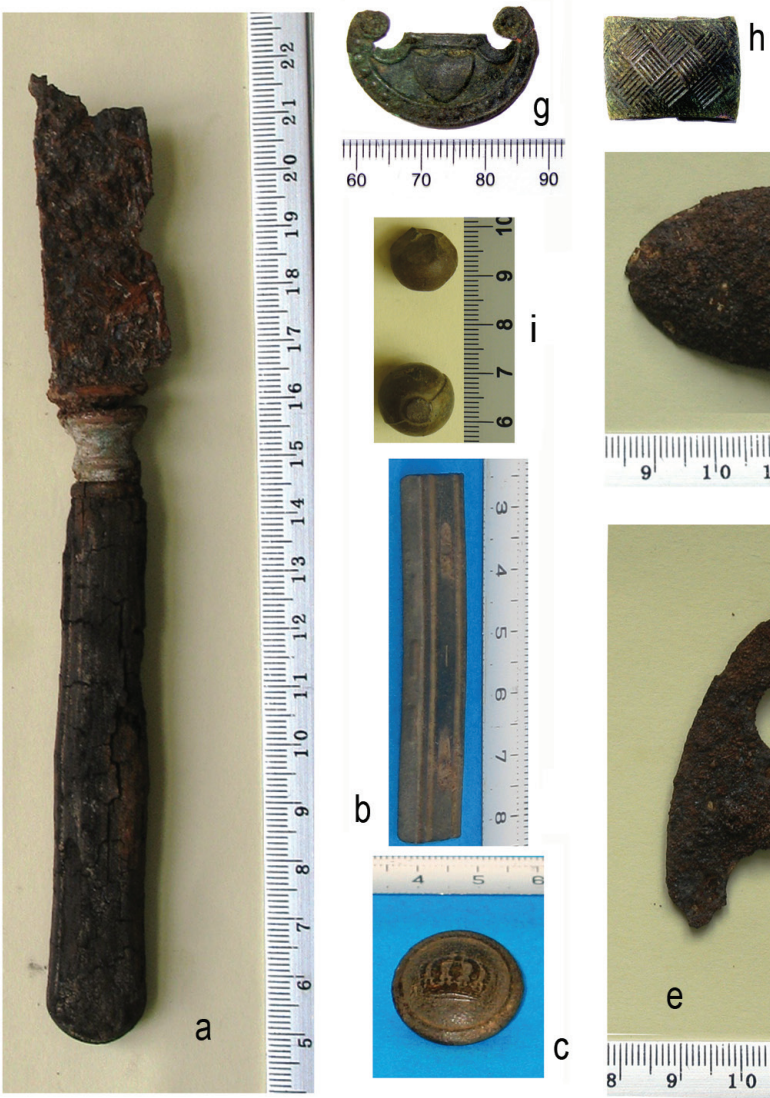

"1|||||||||||||||||||||||||||||||||
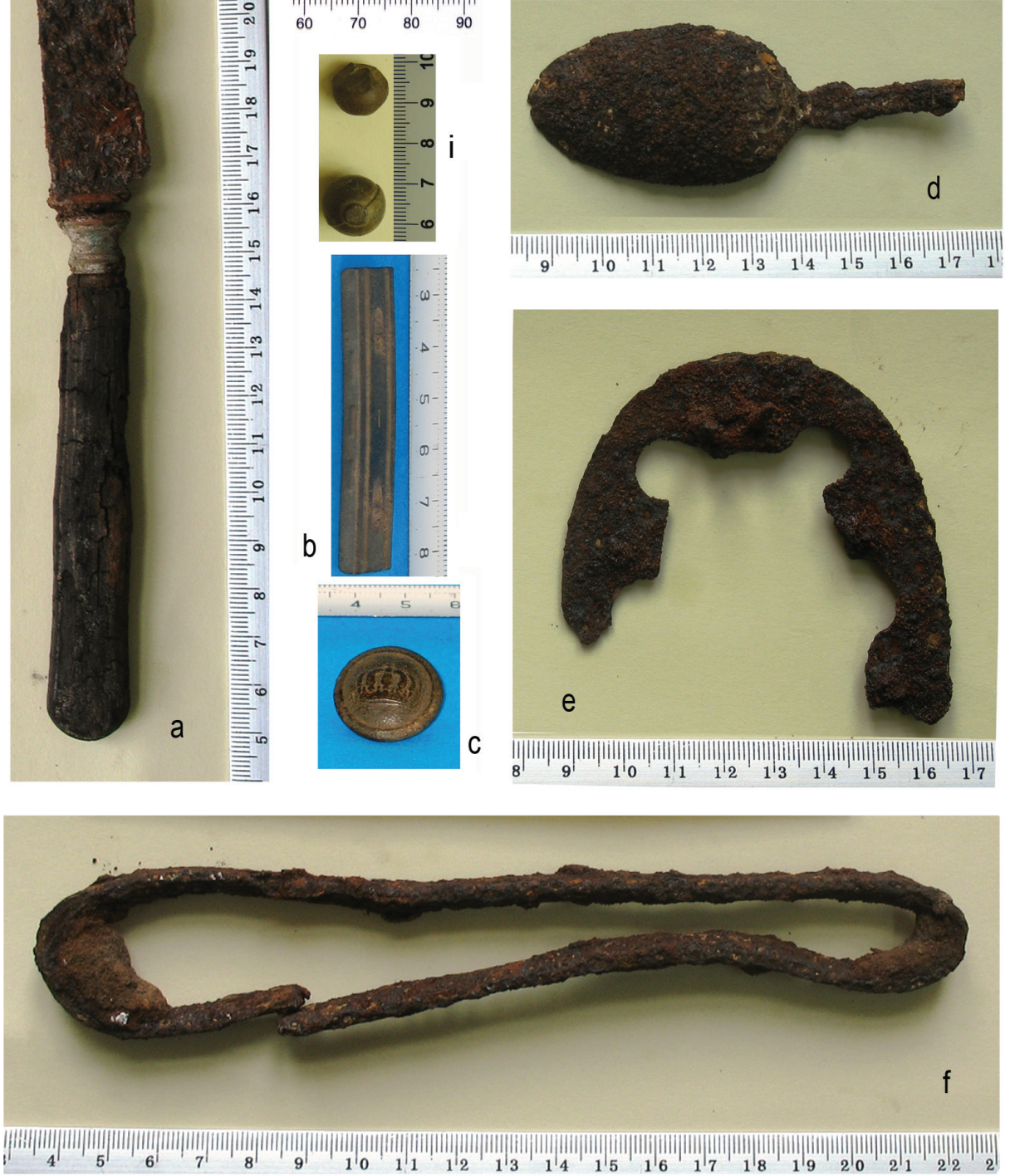

Tablica I. Bolimów, stan. 9, zabytki. a) Fragment stołowego noża z obiektu nr 67; b) Łódka do karabinu Mauser z obiektu nr 1; c) Guzik mundurowy (niemiecki) z humusu; d) Łyżka stołowa z obiektu nr 54; e) Podkówka żołnierskiego buta z obiektu nr 63; f) Zaczep - karabińczyk z obiektu nr 1; g) Herbowa „Tarcza Amazonek” znaleziona w humusie; h) Ornamentowana, brązowa skuwka z humusu; i) Ołowiane kulki szrapneli z humusu (fot. K.E. Natkański). 

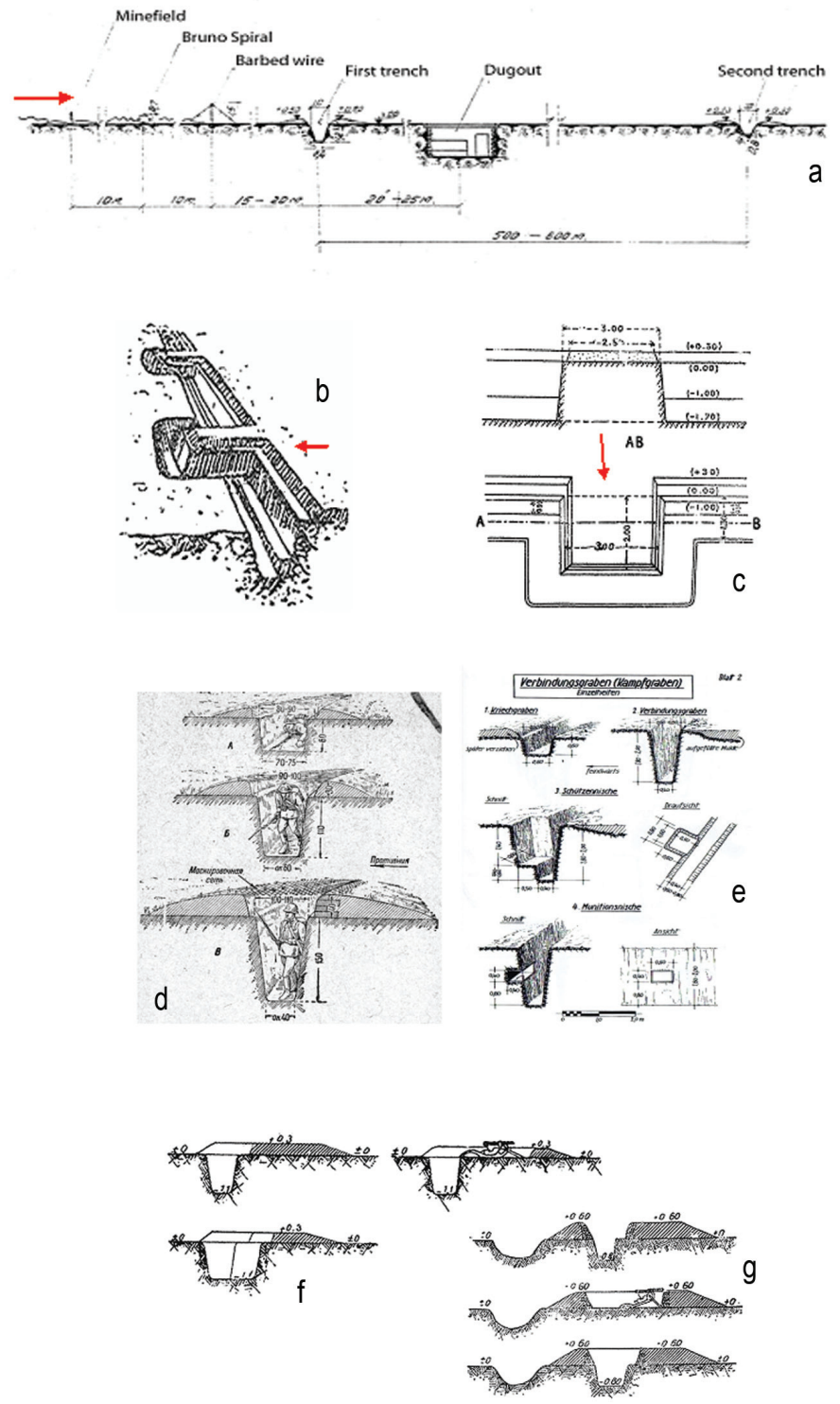

Tablica II. Systemy umocnień (,okopów”) polowych w I wojnie światowej wg regulaminów różnych armii. a) Brytyjski schemat organizacji dwu pierwszych linii okopów na linii frontu (strzałki ukazują spodziewany kierunek ataku); b) Niemiecki schemat budowy typowego okopu (strzałki ukazują spodziewany kierunek ataku); c) Standardowe wymiary niemieckiego okopu; d) Standardowe wymiary okopów rosyjskich; e) Standardowe wymiary okopów niemieckich; f) i g) Standardowe wymiary stanowisk c.k.m. wg regulaminów rosyjskich i niemieckich (Ausbildungsvorschrift...; Podręcznik...). 

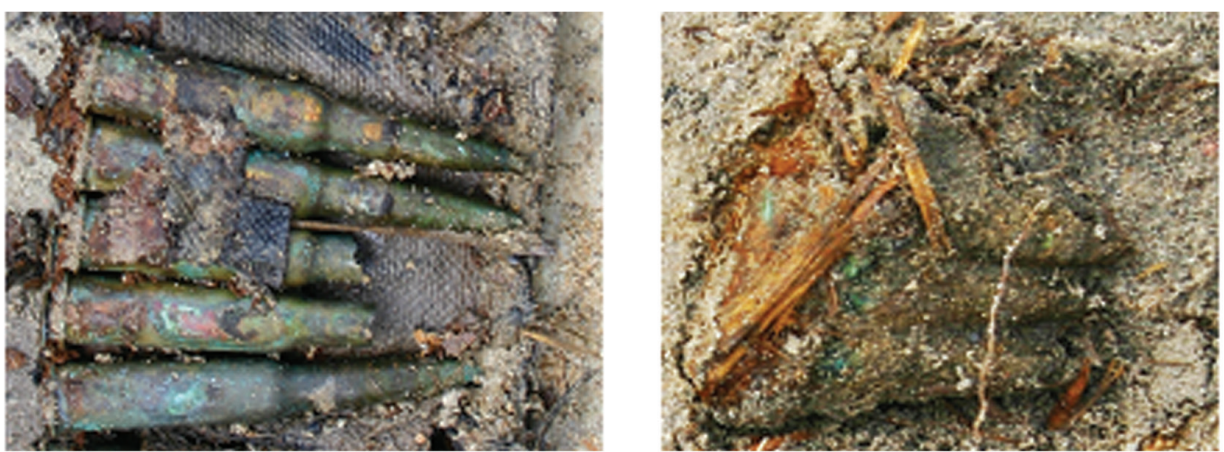

a
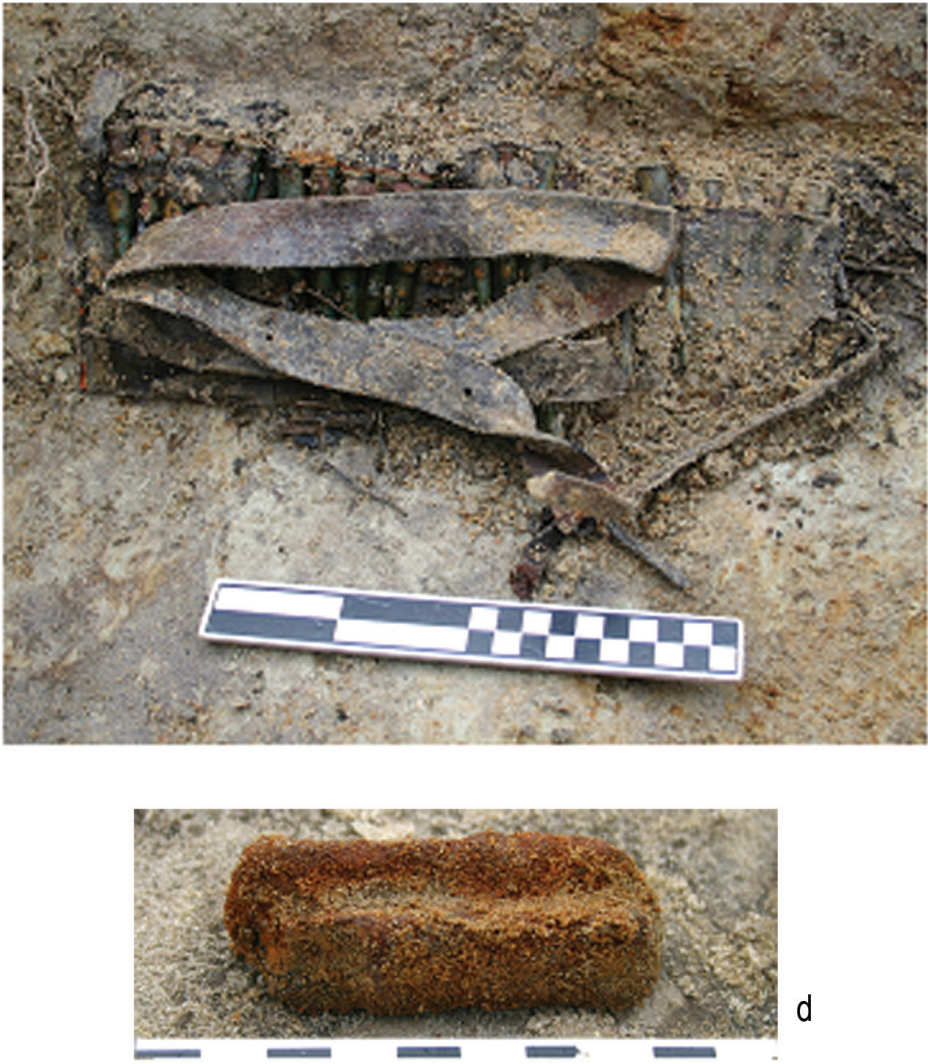

Tablica III. Joachimów-Mogily, stan. 2, zabytki in situ. a) Amunicja rosyjska Mosin 7,62 w bandolierze; b) Amunicja manlicher w ładowniku ,asymetrycznym”(?);

c) Parciany bandolier z pięcioma ładownicami na amunicję; d) Łódka typu Mosin (z wysokimi ,ściankami”) (fot. J. Olejnik). 

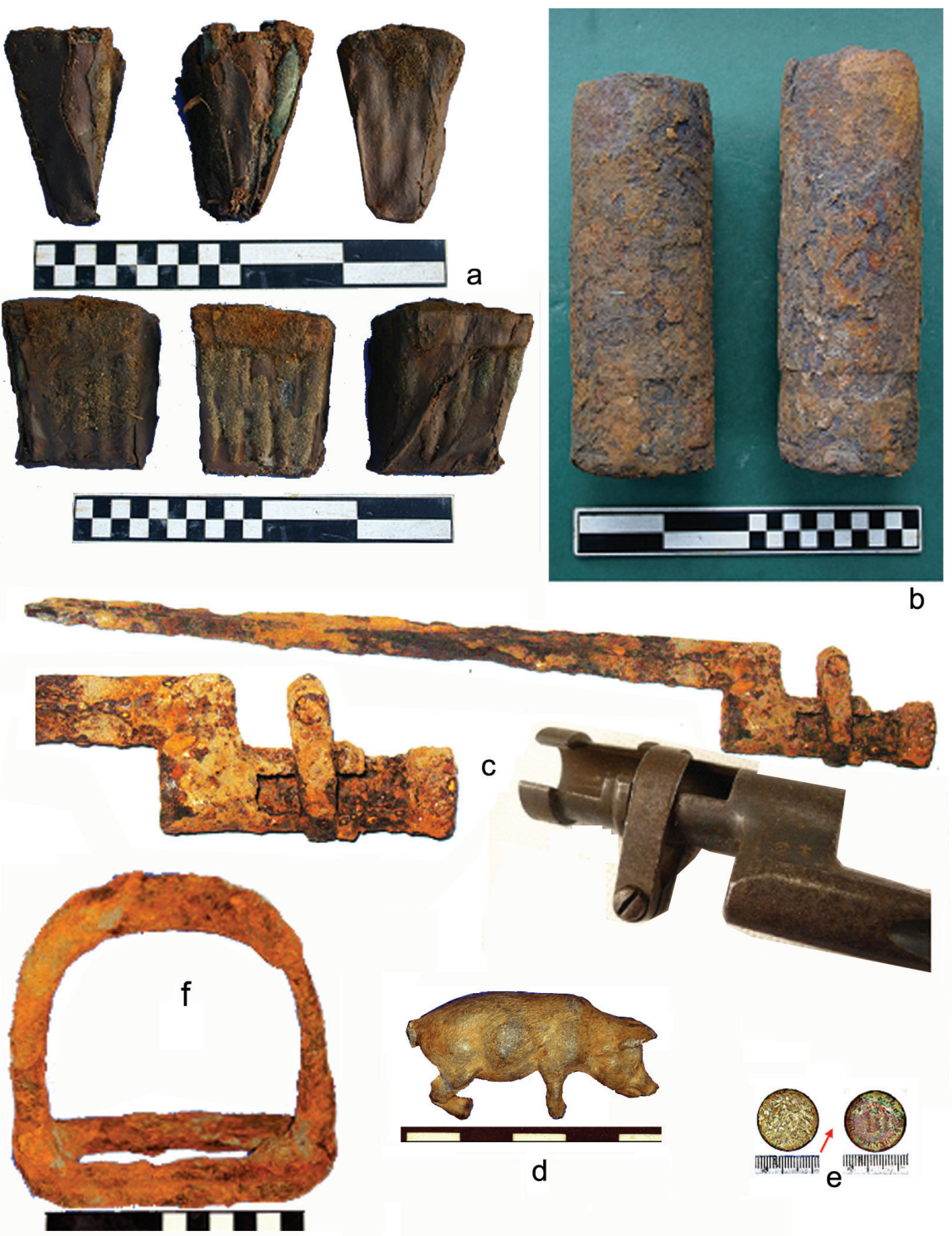

Tablica IV. Joachimów-Mogily, stan. 2, zabytki. a) „Paczki” amunicji rosyjskiej Mosin kal. 7,62 x $54 \mathrm{~mm}$ w łódkach, fabrycznie opakowane natłuszczonym papierem;

b) Dwa „czerepy” rozmontowanych pocisków artyleryjskich (tzw. niewystrzałów) dla niemieckiej armaty pułkowej FK wz. 96 n.A, kal. 7,7 cm, szrapnele(?); c) Bagnet rosyjski, nieskładany, wz. 1891; d) Ołowiana figurka świni; e) Moneta cesarstwa niemieckiego - 10 fenigów;

f) Strzemię rzędu końskiego, najprawdopodobniej niemieckie (fot. J. Olejnik, K.E. Natkański). 

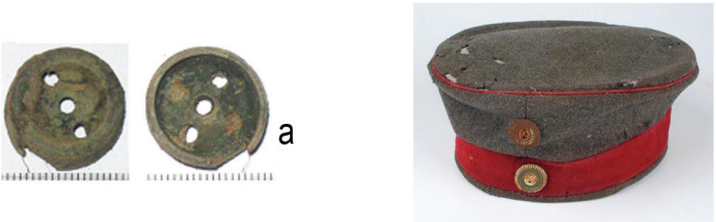

b
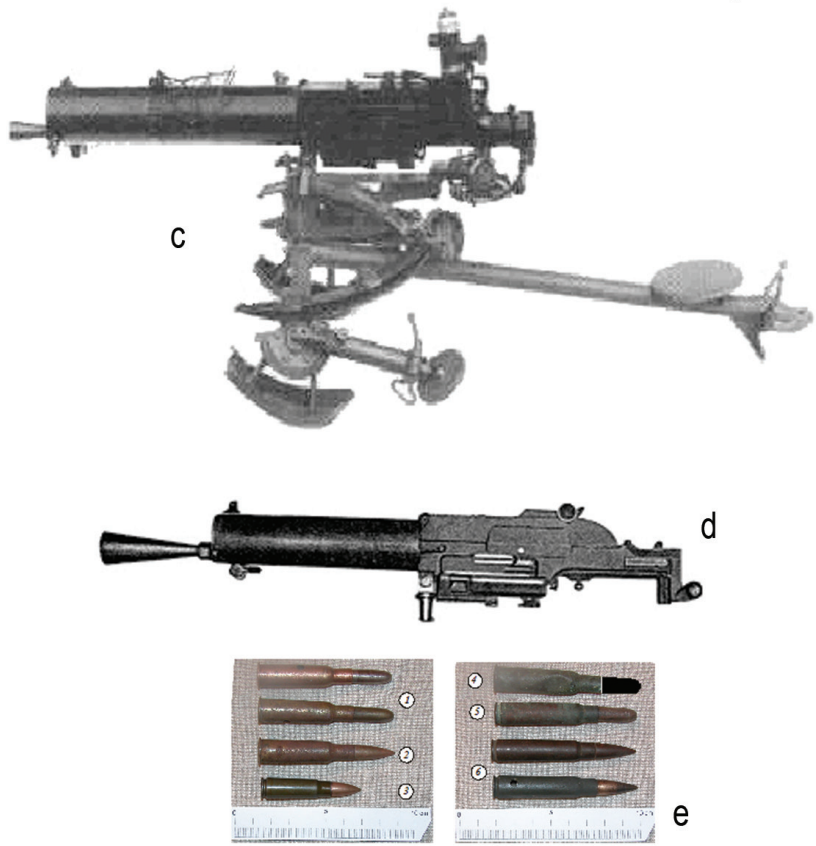

e
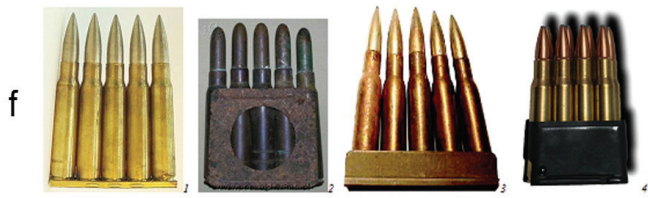

Tablica V. Joachimów-Mogily, stan. 2. a) „Guzik z trzema dziurkami”; b) Fusilier Feldmütze sprzed 1905/1906 roku; c) Austriacki ciężki karabin maszynowy (CKM) Steyer-Schwatzelose (wz. 07/12) kal. 7,9 „na trójnogu”; d) CKM Steyer-Schwartzelose (wz. 08/15) dostosowany do kal. 7,92 bez podstawy; e) Różne odmiany amunicji testowej Mosin 7,62 x 54 mm: 1 ,tępołukowe”; 2 „ostrołukowy”; 3 współczesny nabój „kałasznikow” AK 7,62 x 39 (dla porównania);

4 Steyer-Manlicher 7,9 (łuska bez pocisku);

5 Mauser 7,92 x 57 mm „tępołukowy”; 6 „ostrołukowe”; f) Różne odmiany łódek i ładowników: 1 łódka mauser; 2 ładownik manlicher; 3 łódka Mosin; 4 amerykański ładownik karabinu garand (dla porównania) (fot. K.E. Natkański). 